IFN Working Paper No. 1041, 2014

\title{
Foreign Direct Investment, Source Country Heterogeneity and Management Practices
}

Fredrik Heyman, Pehr-Johan Norbäck and Rickard Hammarberg 


\title{
Foreign Direct Investment, Source Country
}

\section{Heterogeneity and Management Practices}

\author{
Fredrik Heyman \\ Pehr-Johan Norbäck \\ Rickard Hammarberg
}

June 26, 2017

\begin{abstract}
This paper examines whether and, if so, why source country heterogeneity exists in foreign direct investment. Using detailed data on all Swedish firms for the period from 1996 to 2009, we find statistical evidence that affiliate performance differs systematically across source countries. We then show that differences in foreign MNEs' global management practices (estimated from the new firm-level data from the World Management Survey) is an important determinant of productivity among foreign affiliates.
\end{abstract}

JEL: F21, F23, L1, M1

Keywords: Multinational firms, FDI, Management practices, Firm performance 


\section{INTRODUCTION}

It is a stylized fact that multinational enterprises (MNEs) pay higher wages, have higher productivity, and engage in more $\mathrm{R} \& \mathrm{D}$ than indigenous firms. In his seminal work, Dunning (1981) provided an early explanation for this pattern, arguing that MNEs possess unique knowledge of production methods, management practices, and technologies. With the ownership of such firm-specific assets, he argued, MNEs are able to maintain the sales, profits, and productivity levels that are required to cover the additional costs associated with foreign expansion. Firm-specific assets have also been integrated into more formal theories on foreign direct investment (FDI), such as the Knowledge-Capital Model (see Markusen, 2001), and more recent models with heterogeneous firms in which firms select into different entry modes to serve a foreign market conditional on the quality of their firm-specific assets (see e.g. Helpman et al., 2004).

Dunning's original concept was inspired by British industry studies conducted in the 1950s, which revealed that US affiliates were more productive than indigenous British firms. US firms were superior to British firms, he argued, because production factors were better managed in US firms and because management practices constituted a firm-specific asset that could be transferred across borders (from the US to the UK) at little cost.

In this paper, we revisit the question of whether source country-specific differences in productivity exist among foreign affiliates, and if so, what explains such differences. Using detailed matched employer-employee data and information on foreign affiliates located in Sweden and headquartered in 28 source countries, we first establish that significant differences in productivity exist between foreign-owned firms in general and Swedish firms. We then show that this foreign productivity premium masks significant source country differences in productivity among foreign affiliates from different source countries. Using newly available data from the World Management Survey (WMS), ${ }^{1}$ we then find that the 
observed source country heterogeneity in productivity among foreign affiliates is correlated with differences in the global management practices of source country MNEs.

We proceed as follows: In the next section, we briefly discuss why source countryspecific differences in affiliate productivity may arise. From the predictions of recent heterogeneous firms models of FDI, we argue that productivity differences between affiliates from different source countries can stem from both a selection effect generated by host-source pair-specific entry barriers (owing to, e.g. geographical, cultural or other distance to the host country), which compel foreign firms that enter the country to have unusually high productivity, and a source country-specific effect (e.g. from institutions in a broad sense) that affects the productivity of foreign affiliates regardless of the location of the host country. We also discuss different entry modes of FDI and how average differences in productivity between foreign affiliates and indigenous firms may arise through so-called "cherry picking" whereby foreign firms have incentives to purchase high-quality indigenous firms.

Our empirical investigation uses comprehensive and detailed Swedish data on all firms in Sweden for the period from 1997 to 2009. Section II describes the data and our empirical approach. We first estimate the average productivity difference between foreign affiliates from various source countries with ownership in Sweden and indigenous Swedish firms. To control for cherry picking, we estimate how productivity changes after a foreign takeover and compare this takeover effect for different source countries. We also conduct an event analysis to investigate source country differences before takeovers (tracking the target firm from two years before to three years after the event). Section III presents these baseline estimates. We find significant source country-specific productivity differences, regardless of whether the estimates arise from cross-sectional variation or within-firm variation generated by ownership changes. Consistent with Dunning's original finding, we observe that affiliates of US MNEs have approximately 30\% higher productivity than Swedish firms. Affiliates of 
Nordic MNEs and UK MNEs have a productivity premium of only approximately $10 \%$ relative to Swedish firms. Affiliates with France, Germany, Japan, or the Netherlands as the source country lie between these extremes. Regarding foreign acquisitions, we find smaller estimated coefficients (as suggested by foreign cherry picking), but the ranking by source country remains the same. We obtain similar results when we compare foreign affiliates to local Swedish firms and Swedish MNEs and when we divide the estimates into manufacturing and service sectors. The results remain intact when we restrict foreign affiliates to those established as greenfield investments and are also robust to various robustness checks.

Having established that significant productivity differences exist between foreign affiliates from different source countries, Section IV aims to explain these differences and, in particular, to determine whether management practices can provide an explanation for these differences. In a series of important contributions, Nicholas Bloom, Raffaella Sadun, John Van Reenen and co-authors have studied how firms are organized and operated from a management perspective (see Bloom and Van Reenen, 2007, 2010; Bloom et al. 2012a; Bloom et al. 2012b; Bloom et al. 2016b; Bloom et al. 2014, 2016a). They have demonstrated that management practices differ systematically both within and across countries and that firm performance is positively related to firm management quality. ${ }^{2}$

To consider management quality, we first use firm-level data on management practices from the WMS to estimate an index of the quality of management practices for MNEs with headquarters in our source countries. By including host country and year fixed effects, as well as industry fixed effects, we estimate average differences in global management practices for MNEs emanating from source countries with significant ownership in Sweden. We then use this index to estimate the influence of MNEs' source country-specific management practices on the performance of foreign affiliates located in Sweden. 
We find that the global management practices of source country MNEs are correlated with the productivity of their foreign affiliates and that this variable robustly explains source country heterogeneity in affiliate performance. The positive relationship between the global management practices of source country MNEs and the productivity of foreign affiliates in Sweden is also robust to dividing the estimations by sector, using various WMS sub-indices and estimations on a small sub-sample in which we were able to merge Swedish firm-level data with the WMS data to have affiliate-level variation in management practices.

Our paper makes two contributions to the literature. First, the overwhelming majority of the empirical literature on MNEs and FDI examines the effects of FDI on performance in terms of employment, productivity, or wages by comparing national firms and foreign firms with all different source countries combined into a single "foreign ownership" variable. While a few papers have followed Dunning's original work on source country heterogeneity, these studies examine a limited number of source countries. ${ }^{3}$ As our data allow us to identify the source country for each foreign-owned firm in Sweden, we obtain a much richer set of source countries than that used in previous studies. Thus, the first contribution of this paper is to document a high degree of source country heterogeneity in FDI outcomes.

Our second contribution is that we also examine the origin of source country heterogeneity in FDI in detail. In our empirical analysis, we find that an important determinant for affiliate performance is an index of global management practices, which we estimate for affiliates of MNEs headquartered in the identified source countries using the WMS data. We thus contribute to the growing field of the new empirical economics of management, which has demonstrated that a large share of both cross-country and withincountry productivity, as well as productivity gaps between firms, can be explained by differences in management practices. Thus far, this literature has placed less emphasis on source country differences in the management practices of MNEs. An exception is Bloom et 
al. (2012c), who find that US MNEs obtain higher productivity from IT than non-US MNEs or domestic firms in Europe because better (people) management practices in US firms enable them to better exploit IT. Our study thus goes beyond a US vs. non-US comparison of MNEs by documenting large productivity differences among foreign affiliates from numerous source countries and noting that source country-specific variation in management practices of MNEs is an important determinant of these differences. ${ }^{4}$

\section{CONCEPTUAL FRAMEWORK}

Why should foreign affiliates located in the same host country - but headquartered in different source countries - differ in their performance? In this section, we briefly discuss the economic mechanisms that may produce such source country heterogeneity. ${ }^{5}$

From the seminal work of Hymer (1960) the literature on FDI emphasizes that the existence of MNEs rests on the possession of assets that provide a strategic advantage over indigenous firms. Dunning (1981) generalized and synthesized these ideas into his OLIframework to study FDI. Advances in industrial organization allowed the literature to also bring these ideas into more formal models. Product differentiation and scale economies were introduced using the seminal work of Dixit and Stiglitz (1977), with firm heterogeneity introduced by Melitz (2003).

In Helpman et al. (2004) firms first draw their productivity from a given productivity distribution, and then sort into firm types according to their productivity draws. With the fixed cost of entry being lowest in the home market, firms in the lower part of the productivity distribution choose only to serve the home market. Firms in the middle part of the productivity distribution earn enough profit to cover a fixed exporting or marketing cost to also reach consumers in foreign markets by exporting. Firms in the high end of the source country productivity distribution can also cover the fixed cost of opening an affiliate in the 
foreign market as they benefit more from avoiding the variable trade costs associated with exporting due to higher sales. Thus, MNEs emerge as the most productive firm type.

If host country firms' productivity is drawn from the same distribution, the above selection mechanism implies that affiliates of MNEs should on average be more productive than indigenous firms. This selection mechanism can also generate source country heterogeneity among foreign affiliates. To see this, suppose for example that the fixed cost of investing in a plant differs between two source countries, due to - broadly speaking differences in geographical, cultural or some other dimension of distance to the host country. If firms in the two countries draw their productivity from the same underlying distribution, we would expect to observe higher average productivity in the foreign affiliates where the parent firms are headquartered at a larger "distance" from the host country. ${ }^{6}$

Source country characteristics will also matter. Market size, property rights, or the rule of law of the source country affect the incentives of incumbent firms and entrepreneurs to create new innovations, new products or new production methods and brands. Large source countries have more consumers providing stronger incentives for firms to invest in firmspecific assets. Larger markets also encourage entry which intensifies competition, forcing firms to invest in - and/or improve on their existing - firm-specific assets to remain competitive. Source country factors that promote investments into firm-specific assets would shift the distribution of active source country firms towards firms with higher productivity. Thus, not only should then a larger share of source country firms be capable of investing abroad, but the average productivity of these firms would also be higher. ${ }^{7}$

Thus, source country heterogeneity - in terms of the performance of foreign affiliates in a particular host country - can emerge out of a combination of source country-specific hurdles in the host country, and source country characteristics that are conducive to creating high-quality firm-specific assets. Source country differences in the performance of affiliates 
may also pertain to the specific mode of entry of foreign firms into a host country. FDI is typically modelled as a greenfield investment (where an affiliate is established by setting up a new plant). In contrast, stylized facts reveal that almost 70\% of FDI flows emerge from crossborder acquisitions (Antras and Yeaple, 2014). This has also spurred a new stream of literature that analyzes the mechanisms behind cross-border mergers.

Nocke and Yeaple (2007; 2008), for instance, explore the choice between greenfield entry and acquisition entry in a framework where some intangible assets are mobile across borders through ownership, while other intangible assets are immobile. A key feature in their model is assigning intangible assets to exploit synergies with indigenous firms. Diez and Spearot (2014) use a matching model to explore this issue further. In addition to greenfield entry and cross-border acquisitions as potential entry modes, they also consider joint ownership with indigenous parties. Other models emphasize market power associated with acquisitions in oligopoly. Bertrand et al. (2012), for instance, show that an MNE can acquire a domestic target without synergies - or even at dis-synergies - if the target firm's assets are of sufficiently high quality. The reason is that the MNE can raise the product market price ex post, compensating for the lack of synergies with higher consumer prices. Studies such as Guadalope et al. (2012) and Blonigen et al. (2014) also show that foreign firms tend to buy the most productive indigenous firms, so-called "cherry picking". Such cherry picking may also arise if MNEs headquartered in source countries that are tax havens obtain an advantage through higher after-tax profits when buying attractive targets.

\section{EMPIRICAL ANALYSIS}

We now turn to the empirical analysis. In a first step, we explore whether there is source country heterogeneity present among foreign affiliates in Sweden. We will run regressions to establish differences in labor productivity between foreign-owned affiliates and Swedish- 
owned firms, and, in particular, differences in labor productivity between affiliates with parents headquartered in different source countries.

In a second step, we will explore the source of this difference in labor productivity between affiliates from different source countries. The discussion in Section I suggests that source country heterogeneity can stem from countries differing in ability and conditions for creating high-quality firm-specific assets. Foreign affiliates headquartered in source countries with characteristics conducive to high quality firm-specific assets should tend to have higher productivity than foreign affiliates headquartered in source countries with less favorable conditions. Host-source pair specific hurdles such as bilateral distance can also play a role in the selection of firms - as firms headquartered in remote source countries are likely to face higher costs, they also need a higher quality of their assets in order to invest.

In a recent paper, Bloom et al. (2016b) show how management practices can be used to explain heterogeneity both within countries and across countries. We will follow their approach and measure the quality of firm-specific assets of MNEs from different source countries using data from the World Management Survey. We will correlate estimated global management practices of MNEs from different source countries with labor productivity of affiliates in Sweden headquartered in these source countries, using our Swedish firm-level data. To control for the "Sweden-specific hurdle", these regressions also include the source country distance to Sweden and other controls. Thus, we will essentially decompose labor productivity into a source country component (source country management practices) and a host county component (source country distance to Sweden).

\section{Data}

In order to examine whether there are productivity differences between affiliates headquartered in different source countries, we use data from a very extensive and detailed 
database from Statistics Sweden (SCB). The database comprises firm, plant and individual data linked together with unique identification numbers. The analysis covers the period from 1996 to 2009 and is based on all firms with at least 10 employees.

Firm-level data are taken from several register-based datasets from Statistics Sweden that cover the entire private sector. First, the financial statistics contain detailed firm-level information on all Swedish firms in the private sector. Examples of variables include value added, capital stock (book value), number of employees, total wages, ownership status, profits, sales, and industry affiliation. Second, the Regional Labor Market Statistics (RAMS) includes plant-level data on all firms. The RAMS provides firm information on the composition of the labor force with respect to educational level and demographics. Plant-level data are aggregated at the firm level.

To examine the role of the nationality of the foreign-owned firms, we have matched our firm-level data with information from the Swedish Agency for Economic and Regional Growth (Tillväxtanalys), which indicates the nationalities of foreign MNE firms operating in Sweden. The data from the Swedish Agency for Economic and Regional Growth allows us to distinguish among the nationalities (source countries) of the owners of foreign firms that operate in Sweden. The main owner's place of origin defines the nationality. The Agency uses definitions of firm nationality that are in accordance with the definitions used by the OECD and Eurostat for similar data.

Finally, a firm is classified as a foreign-owned MNE if more than 50 percent of the equity is foreign owned. ${ }^{8}$ A foreign acquisition is defined as a firm that switches from being Swedish owned to being foreign owned. All firms, except those that experience more than two ownership changes during the period we study, are included in the analysis. Furthermore, we study only acquisitions of firms for which we have yearly information before and after the 
acquisition. In an online Appendix we show that these restrictions can be relaxed without changing our results.

\section{Descriptive statistics}

This section presents descriptive evidence on source country differences. ${ }^{9}$ We begin by documenting the evolution and importance of foreign ownership in Sweden and then present the evidence on differences between Swedish-owned firms and foreign firms from various countries.

\section{Employment in foreign-owned firms}

Total employment varies substantially in Sweden over the 1996-2009 period. Sweden experienced its greatest economic crisis of the post-war period during the early 1990s, when the competitiveness of Swedish companies in the world market decreased and the Swedish state became very highly leveraged. During the recovery over the following two decades, total employment increased steadily until the IT crisis at the turn of the millennium. As the economy recovered, total employment increased until around the outbreak of the financial crisis in 2008.

Foreign firms were crucial in this process, as employment increased much more in foreign-owned firms than in Swedish-owned firms. In 1996, foreign subsidiaries accounted for less than one-fifth of total employment; by 2009, however, foreign firms represented nearly one-third of total employment in firms with at least 10 employees. More than $80 \%$ of new jobs were created in foreign-owned firms. During this period, the number of foreignowned firms more than doubled, while the corresponding increase in the number of Swedishowned firms was only 35\%. A large share of the increase in foreign ownership occurred through foreign acquisitions, including foreign acquisitions of large Swedish MNEs such as the car producers Volvo and Saab Automobile. The number of acquisitions varies 
significantly over the studied period, with an average of 352 acquisitions of Swedish-owned firms with at least 10 employees per year. ${ }^{10}$

\section{Different source countries}

From which countries does the foreign ownership of Swedish firms primarily originate? In Table 1, we report the share of employment in foreign-owned Swedish firms with owners from ten countries. The selection is based on the countries with the largest number of firms located in Sweden during the period 1996-2009. The figures in Table 1 are presented as annual averages for three separate periods - 1996-2000, 2001-2005, and 2006-2009 - as well as for the entire 1996-2009 period.

Regardless of the period considered, US firms dominate, and approximately $20 \%$ of all workers are employed by a foreign firm with a US parent company. Firms from large European countries such as the UK, Germany, and France together employ approximately $28 \%$ of Swedish workers in foreign-owned firms. Firms from the Nordic countries represent a similar share of foreign employment in Sweden to that of the larger European countries. While the Nordic countries are much smaller, they are geographically closer to Sweden. From the discussion in Section I, firms from countries closer to Sweden are likely to face lower entry costs, which may explain their large presence in Sweden. ${ }^{11}$

The last column in Table 1 reports the average number of affiliates emanating from different source countries during the considered period. Consistent with the employment shares, US firms have the largest number of subsidiaries, followed by Norway and Germany.

\section{Source country differences in performance}

Let us now examine source country differences in affiliate performance. The first column in Tables 2 compares the average labor productivity of foreign firms with owners from the ten major source countries to that of Swedish firms of different types. Regardless of the country 
of origin, foreign subsidiaries have higher average productivity than Swedish firms. US firms have the largest difference: the average difference in labor productivity between a US-owned firm and a Swedish-owned firm is 260,000 SEK. Norwegian firms have the smallest average difference; their labor productivity exceeds that of Swedish firms by a mere 70,000 SEK. This pattern is consistent with the discussion in Section I regarding higher barriers to entry for distant US firms than for closer Nordic firms, which forces US firms that enter Sweden to be more productive, on average, than their Nordic rivals (which, in turn, must be more productive than indigenous Swedish firms, which face the lowest barriers). However, as also noted in that section, such source country-specific differences can also mirror the specific institutions of the source countries. For instance, the large and competitive US market is likely to foster many highly productive firms, some of which will invest abroad.

Finally, Table 2 shows that source country ownership affects affiliate size in terms of the number of employees, the average wages paid by affiliates, and the share of workers with university education. It can be shown that all these measures are highly correlated with affiliate productivity.

\section{Estimating source country differences in productivity}

We now turn to the regression analysis. To investigate whether there are source differences in productivity, we first estimate the following "foreign ownership" regression equation: ${ }^{12}$

$$
\log \left(\frac{V A_{i t}}{L_{i t}}\right)=\delta+\sum_{m} \gamma_{m} D_{i m t}+\varphi \log \left(\frac{K_{i t}}{L_{i t}}\right)+\psi \log \left(L_{i t}\right)+\vartheta \text { Share_skilled } d_{i t}+\mu_{j t}+\varepsilon_{i t} .
$$

The dependent variable in Equation (1) is value added per employee in firm $i$ at time $t$. The dummy variable $D_{\text {imt }}$ is our main interest and contains information on the ownership of firm $i$ at time $t$, where $D_{\text {imt }}=1$ holds if the firm is owned by a firm headquartered in a foreign 
country $m$, and $D_{i m t}=0$ holds if firm $i$ has a Swedish owner. Swedish ownership is then our base category and is captured by the intercept $\delta$; hence, the estimated coefficient $\hat{\gamma}_{m}$ indicates the average percentage difference in labor productivity between a foreign-owned firm with controlling owners located in country $m$ and a Swedish-owned firm in a given industry-year pair. ${ }^{13}$ As in Section 3.2, we let country $m$ represent Denmark, Finland, France, Germany, Japan, the Netherlands, Norway, Switzerland, the UK, and the US, and an aggregate group, "Other Foreign", consisting of the remaining source countries. In Equation (1), we control for a firm's capital intensity and size in terms of employment using logs. The share of skilled workers, which is defined as the percentage share of employees with higher education, is added as an additional control. We also control for combined industry-year fixed effects, $\mu_{j t}$. Finally, $\varepsilon_{i t}$ is the error term. To allow for within-firm correlation over time, standard errors are adjusted for clustering at the firm level.

The foreign firms that are used to estimate Equation (1) are subsidiaries that were established before 1996, were established as start-ups or greenfields during the given period, or were established through acquisitions of Swedish firms. To explore the impact of the mode of entry, we will estimate Equation (1) by only including foreign affiliates that started as greenfield investments. As noted in Section I, differences in labor productivity between foreign-owned firms and Swedish-owned firms might arise because foreign firms tend to acquire (cherry pick) high-quality Swedish firms. To control for cherry picking and unobservable firm characteristics, we also estimate the following "acquisition" equation:

$$
\log \left(\frac{V A_{i t}}{L_{i t}}\right)=\delta+\sum_{m} \gamma_{m} D_{i m t}+\varphi \log \left(\frac{K_{i t}}{L_{i t}}\right)+\psi \log \left(L_{i t}\right)+\vartheta \text { Share_skilled } d_{i t}+\mu_{t}+\phi_{i}+\varepsilon_{i t}
$$


In Equation (2), we include a firm fixed effect $\phi_{i}$ to control for unobserved heterogeneity in productivity and estimate the equation on all Swedish firms that are acquired (as opposed to Equation (1) where we do not include firm fixed effects and study general differences between different source countries). Firms that change ownership may, however, have developed differently from firms that are not acquired. In other words, there may be a concern that the "parallel trends" assumption is violated or, more technically, that acquisitions are correlated with the error term. Our approach to this problem is to address the issue of potentially omitted variables that may be related to the likelihood of being a takeover target. For this purpose, we exploit the fact that not all acquisitions occur during the same period. Given the staggered nature of the data, we can compare the estimates of the full sample of firms to the estimates obtained when we exclude all firms that were never takeover targets from the sample. As identification in both cases comes from within-firm variation, the difference between the two approaches lies in the choice of the control group. ${ }^{14}$ If takeover targets, as a group, have different observable and unobservable characteristics than other firms, using the target sample would provide a better estimate of the actual takeover effect, provided that the characteristics are not time varying.

Thus, in our main specification, Equation (2) is estimated using the sample of Swedish firms that were acquired at some point from 1996 to 2009 by a foreign firm headquartered in country $m .{ }^{15}$ This approach therefore implies that the identification of the influence of foreign ownership stems from the variation over time within firms. In this "difference-in-differences" approach, the estimated coefficient $\hat{\gamma}_{m}$ shows the average difference change in labor productivity that occurs in a Swedish firm after the transition to foreign ownership from source country $m$.

If firm-specific assets are important for firms selecting into firm types as suggested in Section I, we would expect to find differences in the effects on productivity after foreign 
acquisitions of domestic MNEs and local firms. Therefore, we distinguish foreign acquisitions of domestic MNEs from acquisitions of local Swedish firms in Equations (1) and (2). ${ }^{16} \mathrm{We}$ also distinguish between the manufacturing and the service sectors. In addition, we will estimate a version of Equation (2) where the estimate of $\gamma_{m}$ is time-varying. Essentially, this "event analysis" enables us to study the dynamics of the impact of source country ownership on productivity in more detail.

Finally, note that we cannot claim that our estimates of source country heterogeneity are causal. To identify causal effects, we would need to randomly allocate ownership and then measure the effects. Specification (2) is the best approximation of a causal effect, as it allows us to compare the same firm when it is Swedish owned and when it is foreign owned.

\section{SOURCE COUNTRY HETEROGENEITY IN AFFILIATE PRODUCTIVITY}

In this section, we present statistical evidence of cross-country differences in productivity among foreign affiliates headquartered in different source countries. In the next section, we examine the sources of these differences.

\section{Foreign ownership}

As a point of reference, we begin Table 3 with a version of Equation (1) in which we omit firm controls and only estimate a single foreign ownership dummy. Column (1) then indicates that in a given industry-year, foreign-owned firms have approximately $18 \%$ higher labor productivity than Swedish-owned firms. This estimate is statistically significant at the $1 \%$ level and is approximately one-half the size of the foreign productivity premium in Table 2.

In Specification (2), we divide the estimates of foreign ownership into various source countries specified in Equation (1). These estimates (all highly significant) reveal considerable source country heterogeneity: at the top end, we again find that US firms have approximately $30 \%$ higher labor productivity, on average, than Swedish firms; at the bottom, 
we find that firms headquartered in the Nordic countries have only an approximately $10 \%$ higher productivity premium than Swedish firms.

Specification (3) provides the results of estimating Equation (1) with firm controls. We find that adding firm controls reduces the estimated source country differences in productivity. However, the ranking is not affected. This result is further illustrated in Figure A1 (Panel I) in the Appendix, which depicts the point estimates $\hat{\gamma} m$ with their $95 \%$ confidence intervals. When the affiliates are ranked according to source country productivity, US affiliates are followed by Swiss, French, and Japanese affiliates, which are in turn followed by affiliates from the Netherlands and Germany. UK affiliates have a productivity differential from Swedish firms that is similar to that of Nordic firms and thus are at the bottom of the distribution. Other source countries as a group are significantly more productive than Swedish firms but again are in the bottom distribution together with the Nordic firms. ${ }^{17}$

To further explore how foreign ownership depends on the source country, we divide our sample into manufacturing and service sectors. The results are rather similar, although we tend to obtain estimates that are somewhat larger in the service sector (see columns (4) and (5) in Table 3).

Next, we compare foreign-owned firms with non-MNE Swedish firms, i.e. "local firms", and with Swedish MNE firms. We first estimate Equation (1) for local Swedish firms and foreign affiliates and then for Swedish parent firms (the home components of Swedish MNEs) and foreign affiliates. Column (6) reports the estimates with Swedish local firms as the reference, while column (7) provides the estimates with Swedish MNEs as the reference. The results are clear: the significant differences in performance between foreign firms and Swedish firms are predominately attributable to differences between foreign-owned firms and local Swedish firms. While we find that US affiliates have a statistically significant productivity premium relative to Swedish MNEs, Swedish parent MNEs exhibit a statistically 
significant productivity premium relative to affiliates from most other source countries. However, if we compare relative performance measures across source countries, the results for the two control groups of Swedish firms are very similar. ${ }^{18}$

In columns (8)-(10) we use local Swedish firms as the reference group, so that we can also estimate the average difference in productivity between Swedish MNEs and Swedish local firms. While column (8) shows that Swedish MNEs have approximately $15 \%$ higher labor productivity, on average, than Swedish local firms, the relative ranking of foreign affiliates remains the same. Splitting up the data in manufacturing and services in columns (9) and (10), respectively, the US advantage remains while e.g. Swiss affiliates are more productive than Swedish MNEs in manufacturing but not in services. Again, we note that the relative ranking of firms types remains. Local Swedish firms are found to have the lowest productivity.

In Table 4 we re-estimate Table 3 for foreign affiliates which are established through greenfield investments during the studied time period. While results are qualitatively the same as in Table 3, we find somewhat higher differences in productivity between foreign-owned and Swedish-owned firms.

In summary, our results regarding heterogeneity across different foreign owners of Swedish affiliates thus far reveal stable source country differences. These source country differences are robust to the use of different comparison groups, namely, to comparisons of performance between foreign-owned firms and Swedish MNEs or Swedish local firms.

\section{Foreign acquisitions}

We now examine how source country origin affects firm performance in foreign acquisitions of Swedish-owned firms. Table 5 reports the results of estimating Equation (2) on Swedish firms that were acquired at some point during the 1996-2009 period. In column (1), we first 
report the unconditional effect on productivity of a change from Swedish to foreign ownership without accounting for the nationality of the foreign buyer. The point estimate, which is significant at the $5 \%$ level, reveals that a firm transition from Swedish to foreign ownership (irrespective of the source country) is associated with an increase in productivity of approximately $2.4 \%$.

In column (2), we divide foreign ownership by source countries. Again, we find estimated coefficients that are smaller than those presented in column (2) in Table 3. Acquisitions from most source countries do not increase productivity, with the notable exceptions of Dutch acquisitions. Adding firm controls when estimating Equation (2) yield larger and statistically significant estimated productivity increases following US, Dutch and Finnish takeovers (with the largest increase for US takeovers). Dividing the sample into manufacturing and services again yields differences that are more significant (columns (4) and (5)). Dividing Swedish acquired firms into local firms and MNEs, we find that labor productivity significantly increases by nearly $10 \%$ after a US takeover of a local firm, while this effect is not significant when the target is a Swedish MNE. ${ }^{19}$ In comparison, columns (8)(11) show that labor productivity in local Swedish firms increases by up to $4.5 \%$ after an acquisition by a Swedish MNE. ${ }^{20}$

A concern might be that - while the before and after analysis in Table 5 controls for cherry picking of productive Swedish target firms - this procedure may not control for assortative matching in the sense that MNEs with better management acquire more productive firms. In Table A3 in the Appendix, we therefore compare the performance of the acquired affiliates with Swedish firms at the year of the acquisition $(t)$, one $(t-1)$ and two years $(t-2)$ before the acquisition, and one $(t+1)$, two $(t+2)$ and three years or more $(>t+2)$ after the acquisition. Results show that there are no significant differences in productivity between US targets and Swedish firms before the acquisitions - the strong increase in productivity from a 
US acquisition occurs after the acquisition (see columns (1)-(6)). This pattern holds for most other source countries. Similar results can be observed when the reference group consists of foreign acquisitions of local Swedish firms (see columns (7)-(12)).

\section{WHY DO SOURCE COUNTRY DIFFERENCES IN PERFORMANCE ARISE? THE ROLE OF MANAGEMENT PRACTICES}

Why are there differences in productivity across affiliates of different source countries? We will examine whether source country variation in MNEs' management practices can provide an explanation for the observed differences in the productivity of foreign affiliates in Sweden across source countries. Our analysis is based on the following version of Equation (1):

$$
\begin{aligned}
\log \left(\frac{V A_{i t}}{L_{i t}}\right) & =\delta+\text { BManagement }_{m}+\varphi \log \left(\frac{K_{i t}}{L_{i t}}\right)+\psi \log \left(L_{i t}\right)+\text { vShare_skilled }_{i t}+ \\
\boldsymbol{\theta}^{\prime} \boldsymbol{X}_{m t}+\mu_{j t} & +\varepsilon_{i t}
\end{aligned}
$$

In Equation (3), the variable Management $_{m}$ measures time-invariant source country management practices estimated across all host countries in which MNEs from the various source countries with significant ownership in Sweden are active. As is described below, we will estimate this variable using data from the World Management Survey (WMS). Note that we do not include Swedish firms in Equation (3): only foreign affiliates are included. We include only foreign affiliates because we aim to explain the source country differences in productivity between foreign firms that we documented in the previous section. Because of this focus, all of the variation in the variable of interest, namely, management practices, will originate from foreign countries. Equation (3) is estimated on the manufacturing sector since the WMS data that we use cover this sector (see details in the next section). 
Equation (3) also contains a vector of source country-specific gravity variables $\boldsymbol{X}_{m t}$ because management practices by MNEs from different countries may, of course, be correlated with other source country characteristics that are likely to affect investment. From the discussion in Section I, we include geographical distance from the source country to Sweden and source country size. Distance measures the distance between the source country and Sweden and is based on the CEPII measure, which is a population-weighted measure that accounts for internal distances and population dispersion (see Mayer and Zignago (2006)). Size is measured as GDP in constant US dollars. We also include Business Freedom and Freedom to Trade from the Heritage Foundation, as well as Rule of Law from the Worldwide Governance Indicators (WGI) developed by Kaufman et al. (1999) and supplied by the World Bank. Table A1b in the Appendix provides a descriptive overview of all the included variables.

\section{Estimating source country-specific management practices}

We use data from the WMS to estimate our source country management variable, Management $_{m}$. The data originate from the same survey conducted in five major waves, thus expanding the number of surveyed countries from four to a final sample of 34 countries. The WMS is based on randomly drawn samples of mid-size firms in multiple industries. The survey is an interview-based evaluation tool that consists of 18 questions regarding management practices. The answers to each question are rated on a scale from 1 (worst practice) to 5 (best practice). Interviews were conducted with mid-level managers in manufacturing plants, retail stores, hospitals, and schools, who have an overview of the firm's management practices but remain involved in day-to-day work. We will focus on manufacturing data, as this data set gives us the largest coverage of source countries.

Since our Swedish firm-level data span the period 1996-2009 we use data from WMS covering up to the year 2009. ${ }^{21}$ These data for the manufacturing sector is used in e.g. Bloom 
et al. (2012a). The manufacturing data include over 9,000 firm-year observations in 20 host countries. It covers both national and multinational firms. Multinational firms include foreign affiliates and parent firms, that is, the part of the MNEs located in the source country (i.e. domestic MNEs). Approximately 2,400 of these observations involve foreign affiliates whose ownership is spread across 52 source countries. Given our analysis on source country heterogeneity, our approach will be to make use of the source country variation in management practices rather than the host country variation. The reason for this is our interest in measuring the global quality of management practices of MNEs from all source countries which are present as owners of subsidiaries in Sweden. Therefore, we use the source country variable to assign the country of interest rather than the host country variable. The use of this source country affiliation also provides us with a much richer country spectrum to work with compared to host country affiliation.

The remaining observations, when domestic multinationals are excluded, belong to local domestic firms. Parent firms (domestic MNEs) may differ in their activities from affiliates or subsidiaries. Typically, headquarter services such as R\&D and marketing are performed by the parent firm in the source country, while different types of production activities are performed by its foreign affiliates. In what follows, we take an agnostic approach and report specifications where we include or exclude domestic MNEs in the control group of host-country firms.

The WMS data can also be disaggregated into three areas: Monitoring, Targets, and Incentives/People. Monitoring focuses on how well companies observe their internal activities and how well they use this information for continuous improvement. Targets investigate whether companies establish correct targets, track correct outcomes, and take correct actions if the targets and outcomes are inconsistent. Finally, Incentives/People considers whether organizations promote and reward employees based on performance and prioritized hiring 
while attempting to retain their best workers. These sub-indices are of interest because they indicate that management styles can vary within each country and because some countries might receive high scores in some measurement areas but low scores in others. The overall management index is an average of all 18 questions regarding management practices.

Our approach in using the WMS data thus differs from previous studies using these data, as we are interested in extracting source country differences in management practices among MNEs, not mainly country differences. We estimate the following model, which estimates the average difference in management practices between the foreign affiliates of MNEs headquartered in the 28 source countries that have ownership of affiliates in Sweden: ${ }^{22}$

$$
\text { Management }_{\text {ihmt }}=\alpha+\sum_{m \in M} \delta_{m} D_{i h m t}+\vartheta_{h t}+\mu_{j}+\varepsilon_{i m t},
$$

where $i$ indexes firms, $j$ indexes industry, $t$ indexes years, $h$ indexes host country and $m$ indexes the country in which the owners of firm $i$ reside. The dependent variable Management $_{\text {ihmt }}$ is the overall management index. The control group in Equation (4) consists of different combinations of local firms, domestic MNEs and MNEs from other source countries. In our most restricted specifications, we use combined time and host country fixed effects, $\vartheta_{h t}$, as well as industry-specific effects (three-digit SIC), $\mu_{j}$. We then control for variation in management practices that is common to every investigated host country in the WMS data in each survey year.

The estimated coefficients $\hat{\delta}_{m}$ reflect the average difference in management practices between MNEs headquartered in country $m$ and the control group. From the discussion in Section I, the estimates $\hat{\delta}_{m}$ should embody the quality of management practices in the foreign operations of MNEs that stem from the institutions or economic conditions in the source countries of the MNEs, as well as the quality of management practices that MNEs need to 
overcome the cultural or geographical distances between the source country and the various host countries in which the MNEs invest.

We will use different specifications to estimate the country-specific management index. These different versions will then be used alternatively in the productivity regressions (Equation (3)). In our first specification, which we label Management1, Equation (4) is estimated with combined time and host country fixed effects as well as industry-specific effects, excluding host country (parent) MNEs (i.e. domestic MNEs). We also estimate Equation (4), without fixed effects. We label this variable Management2. We then repeat these two specifications on two alternative samples, estimations based on all firms (Management3 and Management4) and only on foreign-owned MNEs (Management5 and Management6).

In Table 6 we report the estimates from Equation (4). Due to space constraints we do not report all 28 coefficients. Table 6 instead shows the estimates for the ten source countries with the largest ownership appearing in Table 4 (the estimates for the other 18 countries are shown in Figure 1 below). Column (1) in Table 6 reports the results for Management1. The baseline for the estimated management index is the constant. The country-specific estimates are then added to the constant, leaving firms headquartered in the US with the highest ranking, with an estimated coefficient of $\hat{\delta}_{U S}=0.513$. From this estimation, we obtain a management index of 4.295 for the US. US MNEs are then followed by MNEs from France, Switzerland, Japan, the Netherlands and Germany. MNEs headquartered in the Nordic countries are at the bottom of the distribution. As reported in the remaining columns in Table 6, the ranking of MNEs from different source countries does not appear to be particularly sensitive to how source country-specific management is estimated: the US remains at the top and the Nordic countries at the bottom. 
Results in Table 6 show that US MNEs score highest on the estimated management index and that the Nordic countries score among the lowest. This hints at a correlation between the estimated source country MNE management index and our estimated average difference in labor productivity between MNEs from different source countries in Table 4. This correlation is illustrated in Figure 1. On the vertical axis we depict the estimated source country coefficients for manufacturing firms $\left(\hat{\gamma}_{m}\right.$ in Equation 1) corresponding to column (4) in Table 4 for all countries with ownership in Sweden. Starting with Panel I, the horizontal axis depicts estimated source country coefficients for the management practices for MNEs headquartered in the 28 source countries estimated from the WMS data ( $\hat{\delta}_{m}$ in Equation 4$)$ corresponding to column (1) in Table 6 (Management1). Since the source countries listed in Table 2 cover the overwhelming majority of foreign affiliates in Sweden, we have weighted the observations with the share of the observations pertaining to the different source countries when illustrating the correlation with a regression line. As seen in the Figure, there is a strong correlation between the average percentage difference in productivity in the manufacturing sector between foreign affiliates and Swedish firms and the estimated average management index for MNEs from the examined source countries. Identical results are also seen when we study Management5 which is estimated only using foreign MNEs in the WMS data (column (5) in Table 6).

\section{Basic Results}

Let us now investigate whether the estimated global management practices of MNEs from different source countries are correlated with labor productivity in the foreign affiliates in our Swedish data? Table 7 presents results from estimating Equation (3), which includes the source country management variable Management $_{m} \cdot{ }^{23}$ 
Starting with Management 1, column (1) in Table 7 reports the unconditional effect of management practices on the productivity of foreign affiliates when we control for only interacted and individual time and industry fixed effects. Specification (2) adds firm controls, as discussed above.

Regardless of which controls are used, columns (1)-(2) indicate that source countryspecific management practices are positively related to the productivity of foreign affiliates in Sweden. The positive correlation between source country-specific productivity and source country management practices, as illustrated in Figure 1, is thus statistically significant after we control for a variety of firm characteristics and even after we include pairwise industry and year fixed effects.

In column (3) in Table 7, we add a set of source country-specific gravity controls. Only the estimate for the source country's Rule of Law is statistically significant. This suggests that better legal institutions foster higher quality firm-specific assets in general, which increases affiliates' productivity. However, source country management remains statistically significant even when we control for these other source country variables.

Studying specification (3) in Table 7, we find that firms with one standard deviation higher management practices are associated with 4.7 log points higher productivity (log value added per employee), i.e. about 5\%. If we compare identical foreign affiliates where one is from the US and another is from Norway, we notice that the estimated management index for the US is 0.35 higher than for Norway (see column (1) in Table 6). This amounts to three standard deviations in the management index (the standard deviation is equal to 0.12 as presented in Table A1b in the Appendix). This means that we would predict that US affiliate should have a productivity advantage of $3 * 0.047 * 100 \% \approx 14 \%$. Interestingly, this number is close to the average difference in productivity between US and Norwegian affiliates found in Table 3. 
Examining the other specifications in Table 7, which presents the alternative measures of source country management, reveals that the relationship between the management practices of source country MNEs and the productivity of affiliates in Sweden is not dependent on our approach for estimating the source country management index (columns (4)-(8)). These results indicate that differences in management practices of MNEs are important for explaining differences in productivity between foreign affiliates. In the next section, we examine the robustness of these results in more detail.

\section{Results on affiliate-level variation in management practices}

A problem with identifying source country effects is that the relationship between productivity in foreign affiliates in Sweden and the global management practices of MNEs is limited to 28 source countries. Yet another problem is that the estimated global source country management practices stem from institutions or economic conditions in the source countries of the MNEs, as well as hurdles from cultural or geographical distance between the source countries and the respective host countries. Re-estimating Equation 3 with affiliate level management practices, while controlling for source country distance to Sweden, offers a potential solution to both problems.

Thus, we continue in this section with an analysis using affiliate-level variation in management practices. We requested and got access to the WMS data with firm identifiers. We merged the Swedish part of the WMS data with data from the Swedish Companies Registration Office (SCRO), where information on firm names and unique identifiers (corporate identity number) are available. ${ }^{24}$ The accounting information in the SCRO data is the source for Statistic Sweden's data on firm-level accounting information. From the SCRO data we obtained labor productivity, capital intensity and size in terms of the number of employees which is not available in the WMS data. A disadvantage with this procedure is that 
it results in a much smaller sample (the sample then only contains the affiliates in Sweden that are present in the WMS data).

Table 8 shows the results from re-estimating Equation (3) with the affiliate-level variation in management practices, where we use the share of managers with college educations and share of non-managers with college educations as controls for the share of skilled workers. $^{25}$

While Table 8 uses a much smaller sample it yields very similar results as our main analysis as shown in Table 7. Columns (1)-(3) use the observations for the years when surveys were conducted in Sweden, while columns (4)-(6) assume that management practices remain constant in a window of two years around the actual year of the observation. Regardless of specification used, affiliate level management practices remain positive and statistically significant. Moreover, the size of the estimated coefficients are very similar to the estimates in Table 7, where we used the estimated source country level management practices of MNEs, thus giving increased confidence in our results.

\section{Different sub-indices of Management practices}

We have also explored that the WMS data can be disaggregated into three areas: Monitoring, Targets, and Incentives. Results are presented in Table A4 in the Appendix. In the first three columns we use the same specification as in column (3) Table 7, but we disaggregate Management (i.e. Management1) into its sub-indices: Monitoring, Targets and Incentives. We then find that Incentives is positively and significantly related to labor productivity. In the last three columns in Table A4, we repeat this procedure when global source country management practices are estimated from a sample that only contains foreign affiliates from the WMS data (i.e. Management5). We then also find that Monitoring is positively and significantly related to labor productivity. 
A closer look at the estimates in Table A4 reveals that the sub-index Incentives is more sharply estimated than the two other sub-indices of management practices. As has been documented in, e.g. Bloom et al. (2012b), Sweden scores relatively low on the incentive index but has the highest calculated index in monitoring and a high value for target management. As suggested by Bloom et al, it may be that countries such as Sweden, which have a strict employment protection, specialize in monitoring and target management, while countries with less stringent employment regulations, such as the US, specialize in incentives. This may explain why US firms with more developed management practices in terms of giving employees stronger incentives can have stronger impact on productivity in Swedish firms than MNEs from, for example, Nordic countries, whose home countries have similar employment protection laws as Sweden.

\section{Additional robustness checks}

We have examined the robustness of our results in a number of ways. As described above, our main results on management practices and productivity are robust to how we estimate the country-specific management index. This section briefly discusses some additional robustness checks.

One issue with our estimates is that the number of observations for each source country both in the Swedish firm-level data and in the WMS data vary considerably. We have therefore re-estimated Tables 7 and 8 using different weighting schemes. When estimating the global source country management practices (Equation 4), the weights include using the number of affiliates from each source country and the number of employees from each source country from the WMS data. In the productivity regressions (Equation (3)), we have used the number of affiliates from each source country and the number of employees from each source country from the Swedish firm-level data as weights. We then use different combinations of 
weights in Equations 3 and 4 to see how this affects results. To save space, these results are presented in the online appendix. Using weighted regressions do not qualitatively or quantitatively change the results in Tables 7 and 8: global source management practices of MNEs are important for explaining differences in productivity between foreign affiliates in Sweden.

Additional robustness checks include estimating Table 7 on a variety of different subsamples. These include only firms with at least 100 employees in the Swedish firm data, only the ten most important source countries active in Sweden, and also several other country combinations. We have also re-estimated Table 8 with different restrictions on how to merge the WMS data with firm identifiers to the Swedish firm-level data base (SCRO) where information on unique firm identifiers are available. Results are qualitatively and quantitatively unaffected by these robustness checks (results are available in the online appendix).

\section{SUMMARY AND CONCLUSIONS}

Is FDI from certain countries preferable to FDI from other countries? Are there differences in productivity among foreign affiliates headquartered in different source countries? If so, why do such source country differences exist?

Using detailed Swedish firm-level data and information on foreign affiliates, we first show that the well-known foreign productivity premium masks significant source country heterogeneity in productivity among foreign affiliates from different source countries. This result holds regardless of whether source country differences in affiliate productivity are estimated along a cross-sectional dimension (comparing Swedish-owned firms with foreign affiliates from different source countries) or from greenfield investments (newly established 
plants) or foreign acquisitions (estimating the influence of a transfer from Swedish to foreign ownership to control for unobserved heterogeneity and cherry picking).

We then turned to considering why source country heterogeneity arises. Using newly available data from the World Management Survey (WMS), we find that a large share of the observed source country variation in productivity among foreign affiliates in Sweden is explained by differences in foreign MNEs' global management practices. This result comes from approaching the WMS data from a new angle in focusing on the source country dimension of the data.

An interesting future research avenue would be to study the full link between source country characteristics, source country firm-specific assets and performance of foreign affiliates in more detail. This would complement recent work in the WMS literature on this issue where Bloom et al. (2012b) have investigated the role of bilateral trust on decentralization within multinational firms, while Bloom et al. (2016b) have explored management as firm-specific technology. Such an analysis would contribute to the literature on heterogeneous firms where there is still relatively little knowledge on why firm heterogeneity exists. $^{26}$

\section{ACKNOWLEDGEMENTS}

We are grateful for helpful comments from David Dorn, Renata Lemos, Trond Randøy, the Editor, three anonymous referees and to Daniela Scur for helping us with access to WMS data with firm identifiers. We have also benefitted from feedback provided by seminar and conference participants at a variety of locations and conferences. Simon Ek and Olga Pugatsova provided excellent research assistance. Fredrik Heyman acknowledges financial support from the Swedish Research Council for Health, Working Life, and Welfare (Forte) the Torsten Söderberg foundation and the Johan and Jakob Söderberg foundation, Pehr-Johan Norbäck and Fredrik Heyman from the Tom Hedelius and Jan Wallander Research 
Foundation and Rickard Hammarberg from the Marianne and Marcus Wallenberg Foundation. The Research Institute of Industrial Economics (IFN), P.O. Box 55665, SE-102 15 Stockholm, Sweden, fredrik.heyman@ifn.se, pehr-johan.norback@ifn.se and rickardhammarberg@gmail.com.

\section{REFERENCES}

ANTRÀs, P. and YeAPle, S. (2014). Multinational firms and the structure of international trade. In G. Gita, E. Helpman and K. Rogoff (eds), Handbook of International Economics, Vol 4. Amsterdam: Elsevier.

BARbosa, N. and LOURI, H. (2002). On the determinants of multinationals' ownership preferences: evidence from Greece and Portugal. International Journal of Industrial Organization, 20(4), 493-515.

Bertrand, O., Hakkala, K., Norbäck, P.-J. and Persson, L. (2012). Should countries block foreign takeovers of R\&D champions and promote greenfield entry? Canadian Journal of Economics, 45(3), 1083-1124.

Blonigen, B. A., Fontagné, L., Sly, N. and Toubal, F. (2014). Cherries for sale: the incidence and timing of cross-border M\&A. Journal of International Economics, 94(2), 341357.

Bloom, N. and VAN ReEnen, J. (2007). Measuring and explaining management practices across firms and countries. Quarterly Journal of Economics, 122(4), 1351-1408.

Bloom, N. and VAN REENEN, J. (2010). Why do management practices differ across firms and countries? The Journal of Economic Perspectives, 24(1), 203-224. 
Bloom, N., Sadun, R. and Van Reenen, J. (2012a). The Organization of firms across countries. Quarterly Journal of Economics, 127(4), 1663-1705.

Bloom, N., Genakos, C., Sadun, R. and Van Reenen, J. (2012b). Management practices across firms and countries. Academy of Management Perspectives, 26(1), 12-33.

Bloom, N., SAdun, R and VAn ReEnen, J. (2012c). Americans do IT better: US multinationals and the productivity miracle. American Economic Review, 102(1), 167-201.

Bloom, N., Lemos, R., Sadun, R., Scur, D. and Van Reenen, J. (2014). The new empirical economics of management. Journal of the European Economic Association, 12(4), $835-1126$.

Bloom, N., Lemos, R., Sadun, R., Scur, D. and Van Reenen, J. (2016a). International data on measuring management practices. American Economic Review: Papers \& Proceeding, 106(5), 152-156.

Bloom, N., SAdun, R. and VAn ReEnen, J. (2016b). Management as a technology? NBER Working Paper no. 22327.

Conyon, M., Girma, S., Thompson, S. and Wright, P. W. (2002). The productivity and wage effects of foreign acquisition in the United Kingdom. Journal of Industrial Economics, $\mathbf{5 0}(1)$

85-102.

Diez, F. J. and Spearot, A. C. (2014). Core competencies, matching and the structure of foreign direct investment. Canadian Journal of Economics, 37(3), 814-855.

Dixit, A. and Stiglitz, J. E. (1977). Monopolistic competition and optimum product diversity. American Economic Review, 67(3), 297-308. 
DunNing, J. H. (1981). International Production and the Multinational Enterprise. London: Allen and Unwin.

Girma, S., Greenaway, D. and WAKelin, K. (1999). Wages, productivity and foreign ownership in UK manufacturing. Working Paper no. 99/14, Center for Research on Globalisation and Labour Markets, University of Nottingham.

GRIFFITH, R. and Simpson, H. (2004). Characteristics of foreign-owned firms in British manufacturing. In D. Card, R. Blundell and R. B. Freeman (eds), Seeking a Premier Economy: The Economic Effects of British Economic Reforms, 1980-2000. Chicago, IL: University of Chicago Press.

Guadalupe, M., Kuzmina, O. and Thomas, C. (2012). Innovation and foreign ownership. American Economic Review, 102(7), 3594-3627.

Helpman, E., Melitz, M. J. and Yeaple, S. (2004). Exports versus FDI with heterogeneous firms. American Economic Review, 94(1), 300-316.

Heyman, F., Norbäck, P.-J. and Hammarberg, R. (2014). Foreign direct investment, source country heterogeneity and management practices. IFN Working Paper no. 1041.

HutTunEn, K. (2007). The effect of foreign acquisition on employment and wages: evidence from Finnish establishments. Review of Economics and Statistics, 89(3), 497-509

HyMER, S. H. (1960). The international operation of national firms: A study of direct foreign investment. Doctoral dissertation, Massachusetts Institute of Technology.

JAVORCEK, B. (2004). Does foreign direct investment increase the productivity of domestic firms? In search of spillovers through backward linkages. American Economic Review, 94(3), 605-627. 
Kaufman, D., KraAy, A. and Zoido-Lobatón, P. (1999). Aggregating governance indicators. World Bank Working Paper no. 2195.

LUNDBERG, L. and KARPATY, P. (2004). Foreign direct investment and productivity spillovers in Swedish manufacturing. Working Papers no. 2004:2, Örebro University, School of Business.

MARKUSEN, J. (2001). General-equilibrium approaches to the multinational firm: a review of theory and evidence. Journal of International Economics, 53(1), 189-204.

MAYER, T. and ZIGNAGO, S. (2006). Notes on CEPII's distance measures. MPRA Working Paper no. 26469.

Melitz, M. J. (2003). The impact of trade on intra-industry reallocations and aggregate industry productivity. Econometrica, 71(6), 1695-1725.

Melitz, M. J. and RedDing, S. J. (2014). Heterogeneous firms and trade. In G. Gita, E. Helpman and K. Rogoff (eds), Handbook of International Economics, Vol 4. Amsterdam: Elsevier.

Nocke, V. and YeAPLE, S. (2007). Cross-border mergers and acquisitions vs. greenfield foreign direct investment: the role of firm heterogeneity. Journal of International Economics, 72(2), 336-365.

Nocke, V. and Yeaple, S. (2008). An assignment theory of foreign direct investment. The Review of Economic Studies, 75(2), 529-557.

Stevenson, B. and Wolfers, J. (2006). Bargaining in the shadow of the law: divorce laws and family distress. Quarterly Journal of Economics, 121(1), 267-288. 


\footnotetext{
${ }^{1}$ See http://worldmanagementsurvey.org/.
}

${ }^{2}$ The evidence presented in Bloom et al. (2016b) indicates that management accounts for up to one-half of the total factor productivity gap between the US and other countries. They also demonstrate that US firms are managed more efficiently than firms from European countries and that this more efficient management is due to the higher level of competition and better legal traditions in the US market. Conditions in the home market of the investing firm can therefore influence the operations of a subsidiary and are hence a potentially important mechanism explaining cross-country differences in FDI outcomes.

${ }^{3}$ Girma et al. (1999), for instance, investigate foreign ownership in the UK's manufacturing sector and examine whether productivity and wage differentials are related to the home country of the ultimate holding companies. This distinction is considered for the US, Japan and others. The results reveal that US firms are the most productive and that they pay the highest wages. Conyon et al. (2002) distinguish instead among acquisitions in the UK by examining the acquirer's country of origin using binary variables for firms from the US, the EU, and other foreign countries. They observe an increase in productivity across all types of foreign acquisitions, with the greatest increase observed for US firms, followed by EU firms, both being significantly larger than for firms from other countries. Finally, Griffith and Simpson (2004) consider foreign-owned firms in the British manufacturing sector and expand the analysis further by including four different countries: the US, France, Germany, and Japan. They find that US firms have become increasingly productive compared to domestic British firms and that US firms are the most productive firms among these four countries. Firms from other countries show no clear patterns.

${ }^{4}$ We also examine the underlying indices of management practices in more detail, showing that MNEs make their foreign affiliates more productive primarily through better incentive systems. This pattern provides some evidence to support the hypothesis in, e.g. Bloom and Van Reenen (2010) that in countries with strong employment protection (such as Sweden), there are weaker incentives to specialize in incentive management. In contrast, in countries in which employment protection is weak - such as in the US - firms have more interest in developing better incentive management. This may explain our finding that productivity is not only higher in Swedish affiliates with US ownership but also that US takeovers are most important in increasing productivity following foreign takeovers. 
${ }^{5}$ In our working paper, Heyman et al. (2014) we sketch a simple oligopoly model that can serve as a useful tool for considering how the source country of ownership affects firm performance and how this ownership effect can be identified in the data.

${ }^{6}$ More precisely, firms from the more distant country would face a higher cut-off productivity to invest in the host-country.

${ }^{7}$ It is outside the scope of this paper to formally explore how source country characteristics impact firms' investments in firm-specific assets in a framework of heterogeneous firms. The literature has only recently started to endogenize the productivity of heterogeneous firms. As Melitz and Redding (2014) note, "this introduces a distinction between a firm's productivity draw upon entry and its measured productivity, which reflects its decisions about product scope, innovation, and technology adoption." If source country characteristics affect actual or measured productivity through endogenous investment choices, this may not only shift the distribution of productivity in the source country. It will also likely affect the productivity cut-offs for investing abroad. If firms can improve on their initial productivity draws, then at unchanged trade- and investment costs, we would expect the productivity cut-off for investing abroad to decline (since savings in trade costs would be larger in more productive firms from their larger sales).

${ }^{8}$ Statistics Sweden uses the common international cutoff of 50 percent to define foreign ownership. Other studies on FDI do not typically find that lower cutoff values affect the results (see e.g. Huttunen, 2007 and Barbosa and Louri, 2002).

${ }^{9}$ Table A1a in the Appendix provides definitions and a descriptive overview of all the included variables.

${ }^{10}$ A major explanation for this increase in foreign ownership is the improved business climate produced by the reforms of the Swedish economy through changes such as the deregulation of capital and foreign exchange markets in the late 1980s and the reduction of barriers to foreign ownership. The large currency crisis in 1992 also reduced the costs of Swedish assets and of locating production in Sweden.

${ }^{11}$ Approximately 4\% of all employees in foreign firms during the 2006-2009 period have owners headquartered in Luxembourg. A potential explanation is that headquartering in Luxembourg entails tax advantages. Due to this we will drop affiliates with headquarters in Luxembourg and other tax havens from the regression analysis in the next section.

${ }^{12}$ Equation (1) can be derived from a Cobb-Douglas production function. See our working paper, Heyman et al. (2014), for derivations. 
${ }^{13}$ If foreign firms generate productivity spillovers, the estimated differences between Swedish firms and foreign affiliates can be seen as lower bounds for the productivity advantage of MNE affiliates, assuming that spillover effects are absent (see e.g. Javorcik, 2004). Lundberg and Karpaty (2004) show evidence using Swedish data.

${ }^{14}$ See Stevenson and Wolfers (2006) for a detailed discussion of such a staggered difference-in-differences approach.

${ }^{15}$ For comparison, we also estimated Equation (2) using the sample of all firms (not only target firms). This estimation provided qualitatively identical results, which are available upon request.

${ }^{16}$ Note that the firms in the analysis on Swedish local firms being acquired by a foreign MNE consist of firms that are either local during the entire period or being acquired by a MNE at some time during the period. The same structure applies to Swedish MNE firms being acquired by a foreign MNE.

${ }^{17}$ Table OA1.1-OA1.3 in the online Appendix tests this hypothesis statistically using Wald tests of the equality of the estimated source country coefficients, i.e., tests of whether $\hat{\gamma}_{m_{j}}=\hat{\gamma}_{m_{k}}$. The top panel in Table OA1.1 reveals that US affiliates have a significantly higher productivity than affiliates from all other source countries. Furthermore, Swiss affiliates have significantly higher productivity than affiliates from most other source countries, while Danish affiliates have lower average productivity than most other source countries.

${ }^{18}$ This similarity is revealed by comparing Panels II and III in Figure A1 in the Appendix. Wald tests in Table OA1.1 in the online Appendix also reveal that we obtain nearly identical results for relative source country performance, regardless of which control group we use.

${ }^{19}$ We have also estimated regressions on a sub-sample of US acquisition of other foreign-owned firms (similar to those in Table 5). Although the individual estimates are mostly not statistically significant, almost all of the estimated coefficient have positive signs (consistent with a productivity premium in US-owned firms). The results are available in Table A2 in the Appendix.

${ }^{20}$ Comparing the estimates for different foreign source countries reveals interesting source country differences. Such differences are illustrated in the middle panels of Figure A1 in the Appendix. Table OA1.3 in the online Appendix provides Wald tests on the differences between the different source country estimates.

${ }^{21}$ More precisely, we use the data set "AMP_graph_manufacturing”. These data and other WMS data can be downloaded at http://worldmanagementsurvey.org/survey-data/download-data/.

${ }^{22}$ The full list of countries is Australia, Bahrain, Belgium, Canada, China, Denmark, Finland, France, Germany, India, Ireland, Iceland, Israel, Italy, Japan, Malaysia, Netherlands, Norway, Poland, Russia, Saudi Arabia, 
Singapore, Spain, Switzerland, Thailand, United Kingdom, Thailand, and United States. We will also present results using other sets of countries, e.g. only analyzing the ten most important source countries.

${ }^{23}$ Following the literature, the management variables are expressed as z-scores (having a mean of zero and unit variance). This means that a unit increase in the standardized variable is equivalent to a standard deviation increase in the unscaled variable.

${ }^{24}$ We could not merge the WMS data with the firm data from Statistics Sweden because the names of the firms are not disclosed in that database. Please see http://www.ifn.se/eng/research/databases_10/ifncd__ifn_corporate database for more information on the SCRO firm data.

${ }^{25}$ The SCRO data data does not include information on the education level of workers.

26 "The productivity of a firm is essentially a black box and relatively little is known on the roles played by production technology, management practises, firm organization and product attributes toward variation in revenues across firms” (Melitz and Redding, 2014). 


\section{Tables and Figures}

Table 1: Country-specific share of total employment in foreign-owned firms and the number of foreign firms, 19962009 (at least 10 employees).

\begin{tabular}{|c|c|c|c|c|c|}
\hline \multirow[b]{2}{*}{$\begin{array}{l}\text { Country of } \\
\text { origin }\end{array}$} & \multicolumn{4}{|c|}{ Share of employment } & \multirow{2}{*}{$\begin{array}{c}\begin{array}{c}\text { Number } \\
\text { of firms } \\
\text { Average } \\
1996- \\
2009\end{array}\end{array}$} \\
\hline & $\begin{array}{l}1996- \\
2000\end{array}$ & $\begin{array}{l}2001- \\
2005\end{array}$ & $\begin{array}{l}2006- \\
2009\end{array}$ & $\begin{array}{c}\text { Average } \\
1996- \\
2009\end{array}$ & \\
\hline US & 0.194 & 0.216 & 0.185 & 0.2 & 519 \\
\hline UK & 0.102 & 0.105 & 0.12 & 0.11 & 275 \\
\hline Finland & 0.113 & 0.105 & 0.102 & 0.11 & 280 \\
\hline Germany & 0.079 & 0.082 & 0.096 & 0.09 & 313 \\
\hline Norway & 0.074 & 0.076 & 0.083 & 0.08 & 370 \\
\hline Denmark & 0.093 & 0.093 & 0.077 & 0.09 & 307 \\
\hline Netherlands & 0.097 & 0.098 & 0.077 & 0.09 & 277 \\
\hline France & 0.081 & 0.075 & 0.072 & 0.08 & 146 \\
\hline Switzerland & 0.111 & 0.052 & 0.043 & 0.06 & 150 \\
\hline Japan & 0.013 & 0.013 & 0.013 & 0.01 & 72 \\
\hline Other & 0.043 & 0.085 & 0.133 & 0.09 & 375 \\
\hline
\end{tabular}

Table 2: Firm characteristics of performance variables, averages 1996-2009 (at least 10 employees)

\begin{tabular}{lcccc}
\hline \hline Country & Productivity & Firm size & Wage & Share skill high \\
\hline Foreign & 610 & 142 & 476 & 0.34 \\
\hline USA & 720 & 166 & 558 & 0.44 \\
France & 640 & 221 & 494 & 0.36 \\
Switzerland & 620 & 179 & 478 & 0.34 \\
UK & 570 & 172 & 473 & 0.4 \\
Finland & 600 & 163 & 457 & 0.28 \\
Luxembourg & 660 & 112 & 491 & 0.36 \\
Japan & 640 & 77 & 519 & 0.36 \\
Germany & 630 & 118 & 478 & 0.31 \\
Netherlands & 610 & 140 & 443 & 0.31 \\
Denmark & 540 & 122 & 423 & 0.28 \\
Norway & 530 & 91 & 435 & 0.27 \\
\hline Swedish & 460 & 50 & 356 & 0.21 \\
Swedish MNE & 610 & 359 & 446 & 0.3 \\
Swedish local & 450 & 40 & 353 & 0.21 \\
\hline Note: Productivity - Value added per employee in 1,000 SEK. Employment - \\
Number of employees. Mean wage - Mean wage cost per employee in 1,000 \\
SEK. Share of high skilled workers - Share of total number of employees with \\
higher education.
\end{tabular}


Table 3: Productivity differences between foreign and Swedish firms, 1996-2009 (at least 10 employees).

\begin{tabular}{|c|c|c|c|c|c|c|c|c|c|c|}
\hline \multirow[b]{3}{*}{ Foreign } & All firms & All firms & All firms & Manu. & Service & $\begin{array}{l}\text { Local } \\
\text { firms }\end{array}$ & MNE & All firms & Manu. & Service \\
\hline & (1) & $(2)$ & (3) & $(4)$ & $(5)$ & $(6)$ & $(7)$ & $(8)$ & $(9)$ & $(10)$ \\
\hline & $\begin{array}{l}0.179 * * * \\
(0.006)\end{array}$ & & & & & & & & & \\
\hline Japan & & $\begin{array}{l}0.215 * * * \\
(0.044)\end{array}$ & $\begin{array}{l}0.137 * * * \\
(0.039)\end{array}$ & $\begin{array}{l}-0.016 \\
(0.063)\end{array}$ & $\begin{array}{l}0.178 * * * \\
(0.044)\end{array}$ & $\begin{array}{l}0.152 * * * \\
(0.039)\end{array}$ & $\begin{array}{l}-0.047 \\
(0.038)\end{array}$ & $\begin{array}{l}0.150 * * * \\
(0.039)\end{array}$ & $\begin{array}{l}0.013 \\
(0.063)\end{array}$ & $\begin{array}{l}0.189 * * * \\
(0.044)\end{array}$ \\
\hline US & & $\begin{array}{l}0.304 * * * \\
(0.016)\end{array}$ & $\begin{array}{l}0.213 * * * \\
(0.015)\end{array}$ & $\begin{array}{l}0.162 * * * \\
(0.028)\end{array}$ & $\begin{array}{l}0.237 * * * \\
(0.017)\end{array}$ & $\begin{array}{l}0.231 * * * \\
(0.015)\end{array}$ & $\begin{array}{l}0.045^{* * *} \\
(0.016)\end{array}$ & $\begin{array}{l}0.230 * * * \\
(0.015)\end{array}$ & $\begin{array}{l}0.196 * * * \\
(0.028)\end{array}$ & $\begin{array}{l}0.250 * * * \\
(0.017)\end{array}$ \\
\hline Denmark & & $\begin{array}{l}0.085 * * * \\
(0.019)\end{array}$ & $\begin{array}{l}0.048 * * * \\
(0.017)\end{array}$ & $\begin{array}{l}0.038 \\
(0.025)\end{array}$ & $\begin{array}{l}0.050 * * \\
(0.021)\end{array}$ & $\begin{array}{l}0.061 * * * \\
(0.017)\end{array}$ & $\begin{array}{l}-0.103^{* * *} \\
(0.018)\end{array}$ & $\begin{array}{l}0.060 * * * \\
(0.017)\end{array}$ & $\begin{array}{l}0.061 * * \\
(0.026)\end{array}$ & $\begin{array}{l}0.060 * * * \\
(0.021)\end{array}$ \\
\hline UK & & $\begin{array}{l}0.160 * * * \\
(0.017)\end{array}$ & $\begin{array}{l}0.086 * * * \\
(0.016)\end{array}$ & $\begin{array}{l}0.090 * * * \\
(0.027)\end{array}$ & $\begin{array}{l}0.089 * * * \\
(0.019)\end{array}$ & $\begin{array}{l}0.103 * * * \\
(0.016)\end{array}$ & $\begin{array}{l}-0.072 * * * \\
(0.018)\end{array}$ & $\begin{array}{l}0.101 * * * \\
(0.016)\end{array}$ & $\begin{array}{l}0.121 * * * \\
(0.028)\end{array}$ & $\begin{array}{l}0.100 * * * \\
(0.019)\end{array}$ \\
\hline Germany & & $\begin{array}{l}0.189 * * * \\
(0.016)\end{array}$ & $\begin{array}{l}0.105 * * * \\
(0.015)\end{array}$ & $\begin{array}{l}0.088 * * * \\
(0.029)\end{array}$ & $\begin{array}{l}0.113 * * * \\
(0.019)\end{array}$ & $\begin{array}{l}0.120 * * * \\
(0.015)\end{array}$ & $\begin{array}{l}-0.054 * * * \\
(0.017)\end{array}$ & $\begin{array}{l}0.119 * * * \\
(0.015)\end{array}$ & $\begin{array}{l}0.114 * * * \\
(0.029)\end{array}$ & $\begin{array}{l}0.125 * * * \\
(0.019)\end{array}$ \\
\hline France & & $\begin{array}{l}0.202 * * * \\
(0.026)\end{array}$ & $\begin{array}{l}0.139 * * * \\
(0.024)\end{array}$ & $\begin{array}{l}0.044 \\
(0.039)\end{array}$ & $\begin{array}{l}0.190 * * * \\
(0.031)\end{array}$ & $\begin{array}{l}0.157 * * * \\
(0.024)\end{array}$ & $\begin{array}{l}-0.015 \\
(0.025)\end{array}$ & $\begin{array}{l}0.157 * * * \\
(0.024)\end{array}$ & $\begin{array}{l}0.079 * * \\
(0.039)\end{array}$ & $\begin{array}{l}0.204 * * * \\
(0.031)\end{array}$ \\
\hline Norway & & $\begin{array}{l}0.102 * * * \\
(0.015)\end{array}$ & $\begin{array}{l}0.073 * * * \\
(0.014)\end{array}$ & $\begin{array}{l}-0.022 \\
(0.023)\end{array}$ & $\begin{array}{l}0.115^{* * * *} \\
(0.018)\end{array}$ & $\begin{array}{l}0.085 * * * \\
(0.014)\end{array}$ & $\begin{array}{l}-0.084 * * * \\
(0.017)\end{array}$ & $\begin{array}{l}0.085^{* * * *} \\
(0.014)\end{array}$ & $\begin{array}{l}0.000 \\
(0.023)\end{array}$ & $\begin{array}{l}0.124 * * * \\
(0.018)\end{array}$ \\
\hline Netherlands & & $\begin{array}{l}0.187 * * * \\
(0.019)\end{array}$ & $\begin{array}{l}0.113 * * * \\
(0.017)\end{array}$ & $\begin{array}{l}0.087 * * * \\
(0.025)\end{array}$ & $\begin{array}{l}0.126 \text { *** } \\
(0.022)\end{array}$ & $\begin{array}{l}0.128 * * * \\
(0.017)\end{array}$ & $\begin{array}{l}-0.028 \\
(0.018)\end{array}$ & $\begin{array}{l}0.127 * * * \\
(0.017)\end{array}$ & $\begin{array}{l}0.116^{* * * *} \\
(0.025)\end{array}$ & $\begin{array}{l}0.136 * * * \\
(0.022)\end{array}$ \\
\hline Finland & & $\begin{array}{l}0.141 * * * \\
(0.018)\end{array}$ & $\begin{array}{l}0.094 * * * \\
(0.017)\end{array}$ & $\begin{array}{l}0.091 * * * \\
(0.023)\end{array}$ & $\begin{array}{l}0.095 * * * \\
(0.025)\end{array}$ & $\begin{array}{l}0.111 * * * \\
(0.017)\end{array}$ & $\begin{array}{l}-0.045^{* *} \\
(0.018)\end{array}$ & $\begin{array}{l}0.111 * * * \\
(0.017)\end{array}$ & $\begin{array}{l}0.123 * * * \\
(0.023)\end{array}$ & $\begin{array}{l}0.106 * * * \\
(0.025)\end{array}$ \\
\hline Switzerland & & $\begin{array}{l}0.224 * * * \\
(0.022)\end{array}$ & $\begin{array}{l}0.146 * * * \\
(0.019)\end{array}$ & $\begin{array}{l}0.137 * * * \\
(0.029)\end{array}$ & $\begin{array}{l}0.155 * * * \\
(0.025)\end{array}$ & $\begin{array}{l}0.163 * * * \\
(0.019)\end{array}$ & $\begin{array}{l}-0.007 \\
(0.020)\end{array}$ & $\begin{array}{l}0.163 * * * \\
(0.019)\end{array}$ & $\begin{array}{l}0.171 * * * \\
(0.029)\end{array}$ & $\begin{array}{l}0.166^{* * * *} \\
(0.025)\end{array}$ \\
\hline Foreign other & & $\begin{array}{l}0.144 * * * \\
(0.019)\end{array}$ & $\begin{array}{l}0.075 * * * \\
(0.017)\end{array}$ & $\begin{array}{l}0.042 * \\
(0.026)\end{array}$ & $\begin{array}{l}0.090 * * * \\
(0.024)\end{array}$ & $\begin{array}{l}0.090 * * * \\
(0.017)\end{array}$ & $\begin{array}{l}-0.083^{* * * *} \\
(0.019)\end{array}$ & $\begin{array}{l}0.089 * * * \\
(0.017)\end{array}$ & $\begin{array}{l}0.070 * * * \\
(0.026)\end{array}$ & $\begin{array}{l}0.101 * * * \\
(0.024)\end{array}$ \\
\hline $\begin{array}{l}\text { Swedish } \\
\text { MNE }\end{array}$ & & & & & & & & $\begin{array}{l}0.150 * * * \\
(0.008)\end{array}$ & $\begin{array}{l}0.138 * * * \\
(0.012)\end{array}$ & $\begin{array}{l}0.182 * * * \\
(0.014)\end{array}$ \\
\hline $\log (\mathrm{K} / \mathrm{L})$ & & & $\begin{array}{l}0.114 * * * \\
(0.001)\end{array}$ & $\begin{array}{l}0.112 * * * \\
(0.003)\end{array}$ & $\begin{array}{l}0.124 * * * \\
(0.002)\end{array}$ & $\begin{array}{l}0.114 * * * \\
(0.001)\end{array}$ & $\begin{array}{l}0.108 * * * \\
(0.004)\end{array}$ & $\begin{array}{l}0.114 * * * \\
(0.001)\end{array}$ & $\begin{array}{l}0.111 * * * \\
(0.003)\end{array}$ & $\begin{array}{l}0.124 * * * \\
(0.002)\end{array}$ \\
\hline $\log (\mathrm{L})$ & & & $\begin{array}{l}0.017 * * * \\
(0.002)\end{array}$ & $\begin{array}{l}0.022 * * * \\
(0.004)\end{array}$ & $\begin{array}{l}0.012 * * * \\
(0.003)\end{array}$ & $\begin{array}{l}0.009 * * * \\
(0.002)\end{array}$ & $\begin{array}{l}0.001 \\
(0.004)\end{array}$ & $\begin{array}{l}0.008 * * * \\
(0.002)\end{array}$ & $\begin{array}{l}0.006 \\
(0.004)\end{array}$ & $\begin{array}{l}0.005^{*} \\
(0.003)\end{array}$ \\
\hline $\begin{array}{l}\text { Share skill } \\
\text { high }\end{array}$ & & & $\begin{array}{l}0.580 * * * \\
(0.010)\end{array}$ & $\begin{array}{l}0.448 * * * \\
(0.027)\end{array}$ & $\begin{array}{l}0.608 * * * \\
(0.010)\end{array}$ & $\begin{array}{l}0.564 * * * \\
(0.009)\end{array}$ & $\begin{array}{l}0.699 * * * \\
(0.027)\end{array}$ & $\begin{array}{l}0.572 * * * \\
(0.009)\end{array}$ & $\begin{array}{l}0.434 * * * \\
(0.027)\end{array}$ & $\begin{array}{l}0.600 * * * \\
(0.010)\end{array}$ \\
\hline Observations & 383,551 & 383,551 & 383,551 & 95,139 & 238,719 & 372,945 & 48,963 & 383,551 & 95,139 & 238,719 \\
\hline R-squared & 0.179 & 0.181 & 0.303 & 0.204 & 0.318 & 0.303 & 0.218 & 0.305 & 0.208 & 0.319 \\
\hline
\end{tabular}


Table 4: Productivity differences between foreign Greenfields and Swedish firms, 1996-2009 (at least 10 employees).

\begin{tabular}{|c|c|c|c|c|c|c|c|c|c|c|}
\hline \multirow[b]{3}{*}{ Foreign } & All firms & All firms & All firms & Manu. & Service & $\begin{array}{l}\text { Local } \\
\text { firms }\end{array}$ & MNE & All firms & Manu. & Service \\
\hline & (1) & (2) & (3) & (4) & (5) & (6) & (7) & (8) & (9) & (10) \\
\hline & $\begin{array}{l}0.214 * * * \\
(0.009)\end{array}$ & & & & & & & & & \\
\hline Japan & & $\begin{array}{l}0.207 * * * \\
(0.056)\end{array}$ & $\begin{array}{l}0.115^{* *} \\
(0.046)\end{array}$ & $\begin{array}{l}0.068 \\
(0.067)\end{array}$ & $\begin{array}{l}0.128 * * \\
(0.052)\end{array}$ & $\begin{array}{l}0.128 * * * \\
(0.046)\end{array}$ & $\begin{array}{l}-0.062 \\
(0.046)\end{array}$ & $\begin{array}{l}0.127 * * * \\
(0.046)\end{array}$ & $\begin{array}{l}0.096 \\
(0.068)\end{array}$ & $\begin{array}{l}0.138 * * * \\
(0.052)\end{array}$ \\
\hline US & & $\begin{array}{l}0.349 * * * \\
(0.023)\end{array}$ & $\begin{array}{l}0.245 * * * \\
(0.021)\end{array}$ & $\begin{array}{l}0.232 * * * \\
(0.042)\end{array}$ & $\begin{array}{l}0.255 * * * \\
(0.023)\end{array}$ & $\begin{array}{l}0.261 * * * \\
(0.021)\end{array}$ & $\begin{array}{l}0.076 * * * \\
(0.022)\end{array}$ & $\begin{array}{l}0.261 * * * \\
(0.021)\end{array}$ & $\begin{array}{l}0.267 * * * \\
(0.042)\end{array}$ & $\begin{array}{l}0.268 * * * \\
(0.023)\end{array}$ \\
\hline Denmark & & $\begin{array}{l}0.104 * * * \\
(0.030)\end{array}$ & $\begin{array}{l}0.057 * * \\
(0.026)\end{array}$ & $\begin{array}{l}0.084 * \\
(0.049)\end{array}$ & $\begin{array}{l}0.046 \\
(0.030)\end{array}$ & $\begin{array}{l}0.071 * * * \\
(0.026)\end{array}$ & $\begin{array}{l}-0.095^{* * *} \\
(0.027)\end{array}$ & $\begin{array}{l}0.070 * * * \\
(0.026)\end{array}$ & $\begin{array}{l}0.111^{* *} \\
(0.049)\end{array}$ & $\begin{array}{l}0.057^{*} \\
(0.030)\end{array}$ \\
\hline UK & & $\begin{array}{l}0.164 * * * \\
(0.028)\end{array}$ & $\begin{array}{l}0.084 * * * \\
(0.024)\end{array}$ & $\begin{array}{l}0.074 * * \\
(0.033)\end{array}$ & $\begin{array}{l}0.089 * * * \\
(0.031)\end{array}$ & $\begin{array}{l}0.099 * * * \\
(0.024)\end{array}$ & $\begin{array}{l}-0.075 * * * \\
(0.025)\end{array}$ & $\begin{array}{l}0.099 * * * \\
(0.024)\end{array}$ & $\begin{array}{l}0.104 * * * \\
(0.034)\end{array}$ & $\begin{array}{l}0.100^{* * *} \\
(0.031)\end{array}$ \\
\hline Germany & & $\begin{array}{l}0.213 * * * \\
(0.023)\end{array}$ & $\begin{array}{l}0.119 * * * \\
(0.021)\end{array}$ & $\begin{array}{l}0.090^{*} \\
(0.047)\end{array}$ & $\begin{array}{l}0.130 * * * \\
(0.026)\end{array}$ & $\begin{array}{l}0.134 * * * \\
(0.021)\end{array}$ & $\begin{array}{l}-0.040^{*} \\
(0.023)\end{array}$ & $\begin{array}{l}0.133 * * * \\
(0.021)\end{array}$ & $\begin{array}{l}0.121 * * * \\
(0.046)\end{array}$ & $\begin{array}{l}0.141 * * * \\
(0.026)\end{array}$ \\
\hline France & & $\begin{array}{l}0.177 * * * \\
(0.036)\end{array}$ & $\begin{array}{l}0.124 * * * \\
(0.035)\end{array}$ & $\begin{array}{l}0.048 \\
(0.052)\end{array}$ & $\begin{array}{l}0.183 * * * \\
(0.044)\end{array}$ & $\begin{array}{l}0.142 * * * \\
(0.035)\end{array}$ & $\begin{array}{l}-0.016 \\
(0.036)\end{array}$ & $\begin{array}{l}0.143 * * * \\
(0.035)\end{array}$ & $\begin{array}{l}0.087 * \\
(0.052)\end{array}$ & $\begin{array}{l}0.196 * * * \\
(0.044)\end{array}$ \\
\hline Norway & & $\begin{array}{l}0.170 * * * \\
(0.027)\end{array}$ & $\begin{array}{l}0.109 * * * \\
(0.024)\end{array}$ & $\begin{array}{l}0.026 \\
(0.031)\end{array}$ & $\begin{array}{l}0.164 * * * \\
(0.034)\end{array}$ & $\begin{array}{l}0.122 * * * \\
(0.024)\end{array}$ & $\begin{array}{l}-0.059 * * \\
(0.024)\end{array}$ & $\begin{array}{l}0.122 * * * \\
(0.024)\end{array}$ & $\begin{array}{l}0.055^{*} \\
(0.031)\end{array}$ & $\begin{array}{l}0.172 * * * \\
(0.034)\end{array}$ \\
\hline Netherlands & & $\begin{array}{l}0.185 * * * \\
(0.031)\end{array}$ & $\begin{array}{l}0.094 * * * \\
(0.027)\end{array}$ & $\begin{array}{l}0.095 * * \\
(0.037)\end{array}$ & $\begin{array}{l}0.095 * * * \\
(0.036)\end{array}$ & $\begin{array}{l}0.109 * * * \\
(0.027)\end{array}$ & $\begin{array}{l}-0.042 \\
(0.026)\end{array}$ & $\begin{array}{l}0.110 * * * \\
(0.027)\end{array}$ & $\begin{array}{l}0.128 * * * \\
(0.038)\end{array}$ & $\begin{array}{l}0.106 * * * \\
(0.036)\end{array}$ \\
\hline Finland & & $\begin{array}{l}0.114 * * * \\
(0.024)\end{array}$ & $\begin{array}{l}0.065^{* * *} * \\
(0.023)\end{array}$ & $\begin{array}{l}0.049 * \\
(0.027)\end{array}$ & $\begin{array}{l}0.076^{*} \\
(0.040)\end{array}$ & $\begin{array}{l}0.082^{* * * *} \\
(0.023)\end{array}$ & $\begin{array}{l}-0.061 * * \\
(0.024)\end{array}$ & $\begin{array}{l}0.082 * * * \\
(0.023)\end{array}$ & $\begin{array}{l}0.085 * * * \\
(0.027)\end{array}$ & $\begin{array}{l}0.086^{* * *} \\
(0.040)\end{array}$ \\
\hline Switzerland & & $\begin{array}{l}0.250 * * * \\
(0.027)\end{array}$ & $\begin{array}{l}0.158 * * * \\
(0.023)\end{array}$ & $\begin{array}{l}0.144 * * * \\
(0.033)\end{array}$ & $\begin{array}{l}0.174 * * * \\
(0.032)\end{array}$ & $\begin{array}{l}0.175^{* * *} \\
(0.023)\end{array}$ & $\begin{array}{l}0.006 \\
(0.025)\end{array}$ & $\begin{array}{l}0.176^{* * * *} \\
(0.023)\end{array}$ & $\begin{array}{l}0.185 * * * \\
(0.033)\end{array}$ & $\begin{array}{l}0.185^{* * *} * \\
(0.032)\end{array}$ \\
\hline $\begin{array}{l}\text { Foreign } \\
\text { other } \\
\end{array}$ & & $\begin{array}{l}0.170 * * * \\
(0.036)\end{array}$ & $\begin{array}{l}0.084 * * * \\
(0.032)\end{array}$ & $\begin{array}{l}0.029 \\
(0.048) \\
\end{array}$ & $\begin{array}{l}0.110^{* * *} \\
(0.044)\end{array}$ & $\begin{array}{l}0.098 * * * \\
(0.032)\end{array}$ & $\begin{array}{l}-0.054 \\
(0.033) \\
\end{array}$ & $\begin{array}{l}0.096^{* * * *} \\
(0.032)\end{array}$ & $\begin{array}{l}0.057 \\
(0.047) \\
\end{array}$ & $\begin{array}{l}0.118^{* * * *} \\
(0.044)\end{array}$ \\
\hline $\begin{array}{l}\text { Swedish } \\
\text { MNE }\end{array}$ & & & & & & & & $\begin{array}{l}0.143 * * * \\
(0.009)\end{array}$ & $\begin{array}{l}0.141 \text { *** } \\
(0.012)\end{array}$ & $\begin{array}{l}0.175^{* * * *} \\
(0.014)\end{array}$ \\
\hline $\log (\mathrm{K} / \mathrm{L})$ & & & $\begin{array}{l}0.115 * * * \\
(0.001)\end{array}$ & $\begin{array}{l}0.112 * * * \\
(0.003)\end{array}$ & $\begin{array}{l}0.126 * * * \\
(0.002)\end{array}$ & $\begin{array}{l}0.115 * * * \\
(0.001)\end{array}$ & $\begin{array}{l}0.114 * * * \\
(0.006)\end{array}$ & $\begin{array}{l}0.115 * * * \\
(0.001)\end{array}$ & $\begin{array}{l}0.111 * * * \\
(0.003)\end{array}$ & $\begin{array}{l}0.125^{* * *} \\
(0.002)\end{array}$ \\
\hline $\log (\mathrm{L})$ & & & $\begin{array}{l}0.020 * * * \\
(0.002)\end{array}$ & $\begin{array}{l}0.023 * * * \\
(0.004)\end{array}$ & $\begin{array}{l}0.016^{* * * *} \\
(0.003)\end{array}$ & $\begin{array}{l}0.012 * * * \\
(0.002)\end{array}$ & $\begin{array}{l}-0.002 \\
(0.005)\end{array}$ & $\begin{array}{l}0.011 * * * \\
(0.002)\end{array}$ & $\begin{array}{l}0.006 \\
(0.004)\end{array}$ & $\begin{array}{l}0.010^{* * * *} \\
(0.003)\end{array}$ \\
\hline $\begin{array}{l}\text { Share skill } \\
\text { high }\end{array}$ & & & $\begin{array}{l}0.577 * * * \\
(0.010)\end{array}$ & $\begin{array}{l}0.436 * * * \\
(0.027)\end{array}$ & $\begin{array}{l}0.608 * * * \\
(0.010)\end{array}$ & $\begin{array}{l}0.562 * * * \\
(0.010)\end{array}$ & $\begin{array}{l}0.748 * * * \\
(0.035)\end{array}$ & $\begin{array}{l}0.569 * * * \\
(0.010)\end{array}$ & $\begin{array}{l}0.424 * * * \\
(0.027)\end{array}$ & $\begin{array}{l}0.601 * * * \\
(0.010)\end{array}$ \\
\hline Observations & 362,344 & 362,344 & 362,344 & 88,837 & 224,825 & 352,100 & 29,918 & 362,344 & 88,837 & 224,825 \\
\hline R-squared & 0.178 & 0.178 & 0.305 & 0.199 & 0.321 & 0.305 & 0.239 & 0.307 & 0.204 & 0.322 \\
\hline
\end{tabular}


Table 5: Productivity differences after acquisitions of Swedish firms by foreign firms 1996-2009 (at least 10 employees).

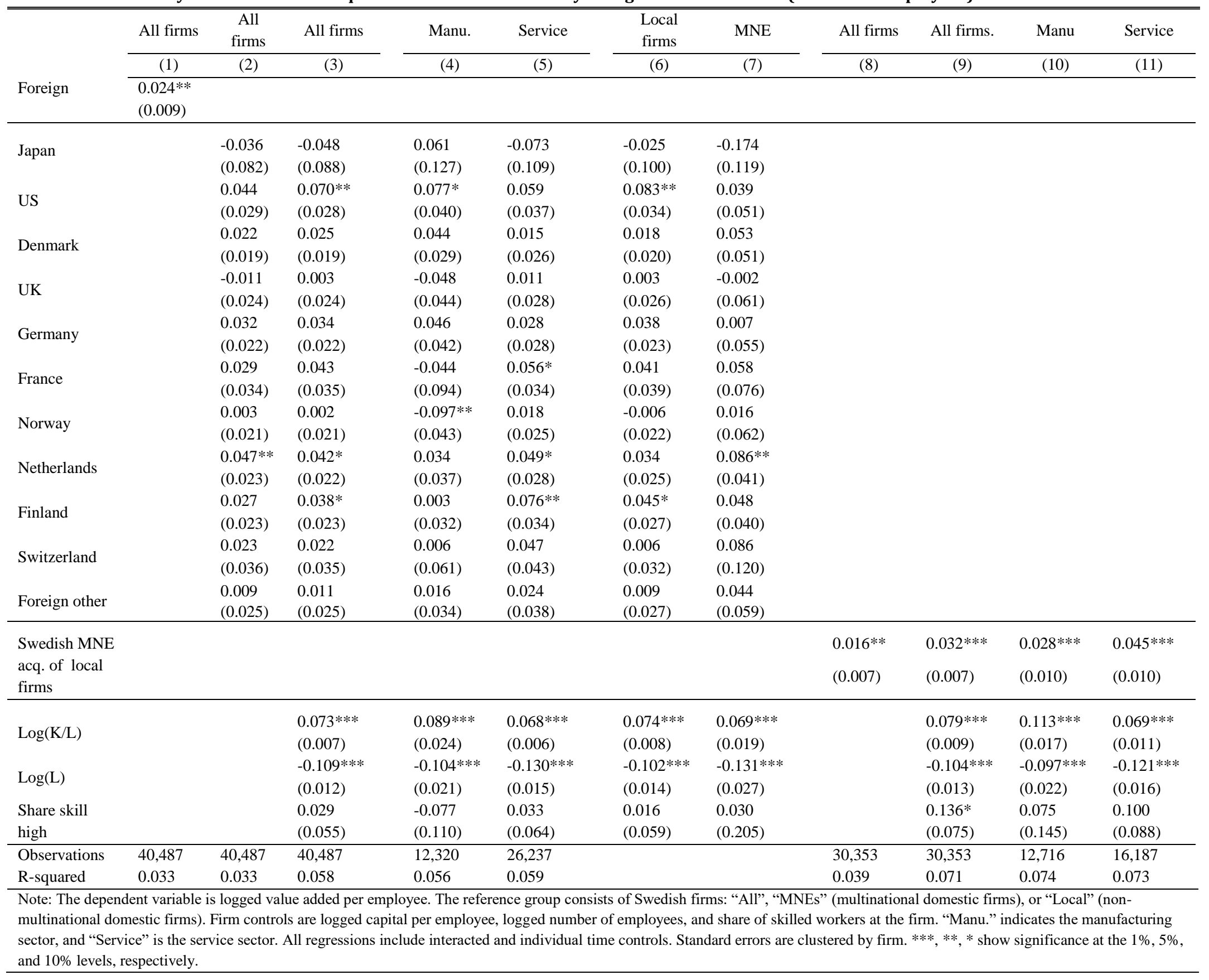


Table 6: WMS management index calculated in different ways, 2000-2009.

Management1 Management2 Management3 Management4 Management5 Management6

\begin{tabular}{|c|c|c|c|c|c|c|}
\hline Denmark & $\begin{array}{l}0.296 * * * \\
(0.100)\end{array}$ & $\begin{array}{l}0.283 * * * \\
(0.101)\end{array}$ & $\begin{array}{l}0.278 * * * \\
(0.100)\end{array}$ & $\begin{array}{l}0.284 * * * \\
(0.100)\end{array}$ & $\begin{array}{l}-0.007 \\
(0.105)\end{array}$ & $\begin{array}{l}0.013 \\
(0.100)\end{array}$ \\
\hline Finland & $\begin{array}{l}0.236 * * * \\
(0.088)\end{array}$ & $\begin{array}{l}0.283 * * * \\
(0.085)\end{array}$ & $\begin{array}{l}0.278 * * * \\
(0.084)\end{array}$ & $\begin{array}{l}0.201 * * \\
(0.088)\end{array}$ & $\begin{array}{l}-0.011 \\
(0.093)\end{array}$ & $\begin{array}{l}0.013 \\
(0.086)\end{array}$ \\
\hline France & $\begin{array}{l}0.474 * * * \\
(0.052)\end{array}$ & $\begin{array}{l}0.471 * * * \\
(0.053)\end{array}$ & $\begin{array}{l}0.361 * * * \\
(0.038)\end{array}$ & $\begin{array}{l}0.370 * * * \\
(0.040)\end{array}$ & $\begin{array}{l}0.145^{* *} \\
(0.065)\end{array}$ & $\begin{array}{l}0.201 \text { **** } \\
(0.062)\end{array}$ \\
\hline Japan & $\begin{array}{l}0.371 * * * \\
(0.049)\end{array}$ & $\begin{array}{l}0.412 * * * \\
(0.049)\end{array}$ & $\begin{array}{l}0.440 * * * \\
(0.043)\end{array}$ & $\begin{array}{l}0.342 * * * \\
(0.045)\end{array}$ & $\begin{array}{l}0.145 * * \\
(0.063)\end{array}$ & $\begin{array}{l}0.142 * * \\
(0.060)\end{array}$ \\
\hline Netherlands & $\begin{array}{l}0.453^{* * *} \\
(0.062)\end{array}$ & $\begin{array}{l}0.366^{* * *} \\
(0.065)\end{array}$ & $\begin{array}{l}0.361 \text { *** } \\
(0.064)\end{array}$ & $\begin{array}{l}0.418 * * * \\
(0.062)\end{array}$ & $\begin{array}{l}0.111 \\
(0.072)\end{array}$ & $\begin{array}{l}0.096 \\
(0.071)\end{array}$ \\
\hline Norway & $\begin{array}{l}0.163 \\
(0.102)\end{array}$ & $\begin{array}{l}0.184^{*} \\
(0.102)\end{array}$ & $\begin{array}{l}0.179 * \\
(0.101)\end{array}$ & $\begin{array}{l}0.133 \\
(0.102)\end{array}$ & $\begin{array}{l}-0.132 \\
(0.108)\end{array}$ & $\begin{array}{l}-0.086 \\
(0.101)\end{array}$ \\
\hline Switzerland & $\begin{array}{l}0.420 * * * \\
(0.060)\end{array}$ & $\begin{array}{l}0.430 * * * \\
(0.061)\end{array}$ & $\begin{array}{l}0.426 * * * \\
(0.060)\end{array}$ & $\begin{array}{l}0.405 * * * \\
(0.060)\end{array}$ & $\begin{array}{l}0.141 * * \\
(0.071)\end{array}$ & $\begin{array}{l}0.160 * * \\
(0.068)\end{array}$ \\
\hline UK & $\begin{array}{l}0.416^{* * * *} \\
(0.055)\end{array}$ & $\begin{array}{l}0.444 * * * \\
(0.055)\end{array}$ & $\begin{array}{l}0.165 * * * \\
(0.029)\end{array}$ & $\begin{array}{l}0.182 * * * \\
(0.035)\end{array}$ & $\begin{array}{l}0.163 * * \\
(0.067)\end{array}$ & $\begin{array}{l}0.174 * * * * \\
(0.064)\end{array}$ \\
\hline Germany & $\begin{array}{l}0.362 * * * \\
(0.040)\end{array}$ & $\begin{array}{l}0.382 * * * \\
(0.040)\end{array}$ & $\begin{array}{l}0.381 * * * \\
(0.031)\end{array}$ & $\begin{array}{l}0.292 * * * \\
(0.033)\end{array}$ & $\begin{array}{l}0.056 \\
(0.056)\end{array}$ & $\begin{array}{l}0.112 * * \\
(0.054)\end{array}$ \\
\hline US & $\begin{array}{l}0.513^{* * * *} \\
(0.029)\end{array}$ & $\begin{array}{l}0.497 * * * \\
(0.027)\end{array}$ & $\begin{array}{l}0.539 * * * \\
(0.022)\end{array}$ & $\begin{array}{l}0.423 * * * \\
(0.024)\end{array}$ & $\begin{array}{l}0.236^{* * *} \\
(0.049)\end{array}$ & $\begin{array}{l}0.226 * * * \\
(0.046)\end{array}$ \\
\hline Constant & $\begin{array}{l}3.782 * * \\
(1.619)\end{array}$ & $\begin{array}{l}2.847 * * * \\
(0.010)\end{array}$ & $\begin{array}{l}2.851 * * * \\
(0.009)\end{array}$ & $\begin{array}{l}2.866 * * * \\
(0.717)\end{array}$ & $\begin{array}{l}3.247 * * * \\
(0.728)\end{array}$ & $\begin{array}{l}3.116^{* * * *} \\
(0.040)\end{array}$ \\
\hline Sample in WMS & $\begin{array}{l}\text { Domestic } \\
\text { firms and } \\
\text { foreign MNEs }\end{array}$ & $\begin{array}{c}\text { Domestic } \\
\text { firms and } \\
\text { foreign MNEs }\end{array}$ & All firms & All firms & $\begin{array}{l}\text { Foreign } \\
\text { MNEs }\end{array}$ & $\begin{array}{l}\text { Foreign } \\
\text { MNEs }\end{array}$ \\
\hline $\begin{array}{l}\text { Pairwise } \\
\text { country and } \\
\text { year FE }\end{array}$ & Yes & No & No & Yes & Yes & No \\
\hline Industry FE & Yes & No & No & Yes & Yes & No \\
\hline Observations & 6,367 & 6,789 & 8,550 & 7,999 & 2,176 & 2,336 \\
\hline R-squared & 0.227 & 0.084 & 0.091 & 0.200 & 0.126 & 0.029 \\
\hline
\end{tabular}

Note: For expositional reasons we only display the estimates for the 10 largest source countries in Sweden corresponding to Tables 1-7. The estimates for the remaining 18 source countries with ownership in Sweden are suppressed. Management 1 - w/o domestic multinationals, controls for year and country fixed effect integrated and industry fixed effects. Management 2 - w/o domestic multinationals, also equal to average index by country across the entire period. Management 5 - on the sample of foreign MNEs, controls for year and country effect integrated and industry effects. Management6 - on the sample of foreign MNEs, also equal to average index by country across the entire period. ***,**, * show significance at the $1 \%$, $5 \%$, and $10 \%$ levels, respectively. 
Table 7: Management and productivity, 2000-2009 (at least 10 employees). Comparing management indices.

\begin{tabular}{|c|c|c|c|c|c|c|c|c|}
\hline \multirow[b]{3}{*}{ Management } & \multicolumn{3}{|c|}{ Management 1} & \multirow{2}{*}{$\begin{array}{c}\text { Management } 2 \\
(4)\end{array}$} & \multicolumn{3}{|c|}{ Management 5} & \multirow{2}{*}{$\begin{array}{c}\text { Management } 6 \\
(8)\end{array}$} \\
\hline & (1) & (2) & (3) & & (5) & (6) & (7) & \\
\hline & $\begin{array}{l}0.082^{* * *} \\
(0.030)\end{array}$ & $\begin{array}{l}0.056^{* * *} \\
(0.022)\end{array}$ & $\begin{array}{l}0.047 * \\
(0.023)\end{array}$ & $\begin{array}{c}0.063 * * \\
(0.025)\end{array}$ & $\begin{array}{c}0.092 * * * \\
(0.030)\end{array}$ & $\begin{array}{c}0.066^{* * * *} \\
(0.019)\end{array}$ & $\begin{array}{l}0.059 * * \\
(0.022)\end{array}$ & $\begin{array}{c}0.063 * * \\
(0.025)\end{array}$ \\
\hline $\log (\mathrm{K} / \mathrm{L})$ & & $\begin{array}{c}0.117 * * * \\
(0.011)\end{array}$ & $\begin{array}{c}0.117 * * * \\
(0.011)\end{array}$ & $\begin{array}{c}0.117 * * * \\
(0.011)\end{array}$ & & $\begin{array}{c}0.117 * * * \\
(0.011)\end{array}$ & $\begin{array}{c}0.117 * * * \\
(0.011)\end{array}$ & $\begin{array}{c}0.117 * * * \\
(0.011)\end{array}$ \\
\hline $\log (\mathrm{L})$ & & $\begin{array}{c}0.026^{* * *} \\
(0.012)\end{array}$ & $\begin{array}{c}0.025^{* *} \\
(0.012)\end{array}$ & $\begin{array}{c}0.025^{* *} \\
(0.012)\end{array}$ & & $\begin{array}{c}0.025^{* *} \\
(0.012)\end{array}$ & $\begin{array}{c}0.025^{* *} \\
(0.012)\end{array}$ & $\begin{array}{l}0.025^{* *} \\
(0.012)\end{array}$ \\
\hline $\begin{array}{l}\text { Share skill } \\
\text { high }\end{array}$ & & $\begin{array}{c}0.693 * * * * \\
(0.096)\end{array}$ & $\begin{array}{c}0.689^{* * * *} \\
(0.094)\end{array}$ & $\begin{array}{c}0.695 * * * \\
(0.093)\end{array}$ & & $\begin{array}{c}0.693^{* * *} \\
(0.096)\end{array}$ & $\begin{array}{c}0.692^{* * * *} \\
(0.093)\end{array}$ & $\begin{array}{c}0.695 * * * \\
(0.093)\end{array}$ \\
\hline GDP & & & $\begin{array}{c}0.00955 \\
(0.00693)\end{array}$ & $\begin{array}{c}0.00929 \\
(0.00713)\end{array}$ & & & $\begin{array}{c}0.00970 \\
(0.00710)\end{array}$ & $\begin{array}{c}0.00933 \\
(0.00713)\end{array}$ \\
\hline Distance & & & $\begin{array}{l}-0.0516 \\
(0.111)\end{array}$ & $\begin{array}{l}-0.0490 \\
(0.117)\end{array}$ & & & $\begin{array}{l}-0.0693 \\
(0.121)\end{array}$ & $\begin{array}{l}-0.0490 \\
(0.117)\end{array}$ \\
\hline Rule of law & & & $\begin{array}{l}0.045^{* *} \\
(0.020)\end{array}$ & $\begin{array}{l}0.044^{*} \\
(0.022)\end{array}$ & & & $\begin{array}{l}0.044 * \\
(0.022)\end{array}$ & $\begin{array}{l}0.044 * \\
(0.022)\end{array}$ \\
\hline $\begin{array}{l}\text { Business } \\
\text { freedom }\end{array}$ & & & $\begin{array}{l}-0.001 \\
(0.012)\end{array}$ & $\begin{array}{l}-0.003 \\
(0.011)\end{array}$ & & & $\begin{array}{l}-0.005 \\
(0.010)\end{array}$ & $\begin{array}{l}-0.003 \\
(0.011)\end{array}$ \\
\hline $\begin{array}{l}\text { Freedom to } \\
\text { trade }\end{array}$ & & & $\begin{array}{l}-0.050 \\
(0.043)\end{array}$ & $\begin{array}{l}-0.042 \\
(0.042)\end{array}$ & & & $\begin{array}{l}-0.043 \\
(0.040)\end{array}$ & $\begin{array}{l}-0.042 \\
(0.042)\end{array}$ \\
\hline $\begin{array}{l}\text { Observations } \\
\text { R-squared }\end{array}$ & $\begin{array}{l}8,813 \\
0.060\end{array}$ & $\begin{array}{l}8,813 \\
0164\end{array}$ & $\begin{array}{l}8,813 \\
0.166\end{array}$ & $\begin{array}{l}8,813 \\
0.059\end{array}$ & $\begin{array}{l}8,813 \\
0.061\end{array}$ & $\begin{array}{l}8,813 \\
0.165\end{array}$ & $\begin{array}{l}8,813 \\
0.167\end{array}$ & $\begin{array}{l}8,813 \\
0.167\end{array}$ \\
\hline $\begin{array}{l}\text { Note: The de } \\
\text { domestic mul } \\
\text { average index } \\
\text { effects. Mana } \\
\text { individual tin } \\
\text { respectively. }\end{array}$ & $\begin{array}{l}\text { ndent variabl } \\
\text { nationals, con } \\
\text { by country ac } \\
\text { ement6 - on } \\
\text { and industry }\end{array}$ & $\begin{array}{l}\text { logged value } \\
\text { for year and } \\
\text { the entire pe } \\
\text { sample of for } \\
\text { ed effects as }\end{array}$ & $\begin{array}{l}\text { led per emplo } \\
\text { untry fixed eff } \\
\text { d. Manageme } \\
\text { n MNEs, also } \\
11 \text { as clustered }\end{array}$ & $\begin{array}{l}\text { anagement indic } \\
\text { tegrated and ind } \\
\text { on the sample } \\
\text { to average ind } \\
\text { ard errors at the }\end{array}$ & $\begin{array}{l}\text { r different sc } \\
\text { fixed effects } \\
\text { eign MNEs, } \\
\text { country acr } \\
\text { try level. ** }\end{array}$ & $\begin{array}{l}\text { countries ar } \\
\text { anagement } 2 \\
\text { trols for year } \\
\text { the entire per } \\
* \text { * }{ }^{*} \text { show si }\end{array}$ & $\begin{array}{l}\text { ken from Tal } \\
\text { o domestic } n \\
\text { d country eff } \\
\text { All regressi } \\
\text { icance at the }\end{array}$ & $\begin{array}{l}\text { agement } 1-\text { w/o } \\
\text { als, also equal to } \\
\text { ited and industry } \\
\text { de interacted and } \\
\text { and } 10 \% \text { levels, }\end{array}$ \\
\hline
\end{tabular}


Table 8. Management and productivity (at least 10 employees). Results using merged WMS and Swedish firm level data

\begin{tabular}{|c|c|c|c|c|c|c|}
\hline \multirow{3}{*}{ Management } & (1) & (2) & (3) & (4) & (5) & (6) \\
\hline & $0.077 * *$ & $0.071 * *$ & $0.073 * *$ & $0.053 *$ & $0.053^{*}$ & $0.055^{*}$ \\
\hline & $(0.035)$ & $(0.033)$ & $(0.035)$ & $(0.031)$ & $(0.029)$ & $(0.030)$ \\
\hline \multirow[t]{2}{*}{$\log (\mathrm{K} / \mathrm{L})$} & & $0.200 * * *$ & $0.195 * * *$ & & $0.218 * * *$ & $0.210 * * *$ \\
\hline & & $(0.038)$ & $(0.040)$ & & $(0.037)$ & $(0.037)$ \\
\hline \multirow[t]{2}{*}{$\log (\mathrm{L})$} & & 0.016 & 0.012 & & 0.007 & 0.001 \\
\hline & & $(0.044)$ & $(0.046)$ & & $(0.036)$ & $(0.036)$ \\
\hline \multirow{2}{*}{$\begin{array}{l}\text { Share of skilled } \\
\text { managers }\end{array}$} & 0.000 & -0.000 & -0.001 & 0.000 & 0.000 & -0.000 \\
\hline & $(0.001)$ & $(0.001)$ & $(0.001)$ & $(0.001)$ & $(0.001)$ & $(0.001)$ \\
\hline \multirow{2}{*}{$\begin{array}{l}\text { Share of skilled } \\
\text { non-managers }\end{array}$} & 0.002 & $0.004 *$ & $0.004 * *$ & 0.004 & $0.006^{* *}$ & $0.006 * *$ \\
\hline & $(0.002)$ & $(0.002)$ & $(0.002)$ & $(0.002)$ & $(0.002)$ & $(0.002)$ \\
\hline \multirow[t]{2}{*}{ GDP } & & & 0.00587 & & & 0.00273 \\
\hline & & & $(0.0110)$ & & & $(0.0105)$ \\
\hline \multirow{2}{*}{ Distance } & & & -0.0753 & & & -0.13 \\
\hline & & & $(0.157)$ & & & $(0.114)$ \\
\hline \multirow[t]{2}{*}{ Rule of law } & & & 0.119 & & & 0.006 \\
\hline & & & (0.109) & & & $(0.074)$ \\
\hline Business & & & -0.050 & & & -0.040 \\
\hline freedom & & & $(0.088)$ & & & $(0.070)$ \\
\hline Freedom to & & & $-0.362 *$ & & & -0.089 \\
\hline trade & & & $(0.217)$ & & & $(0.125)$ \\
\hline Observations & 143 & 143 & 143 & 426 & 426 & 426 \\
\hline R-squared & 0.248 & 0.412 & 0.432 & 0.213 & 0.381 & 0.392 \\
\hline
\end{tabular}

Note: The dependent variable is logged value added per employee. The independent variable of interest is firm-level WMS management score (instead of aggregated country-level score). Columns (1)-(3) include observations and corresponding management scores for 2006 and 2010. Columns (4)-(6) include observations for 2004-2011, where the management score for each firm has been imputed using the closest available observation (2006 or 2010). Firm controls are logged capital per employee, logged number of employees (from the Swedish firm level data), and share of skilled managers and share of skilled non-managers at firm (from the WMS data). Country controls include GDP, CEPII population weighted distance measure, WGI level of legal institutions "Rule of Law", and Heritage Foundation measures of economic freedom. All regressions include interacted and individual time and industry fixed effects as well as clustered standard errors at the firm level. Robust standard errors in parentheses: $\quad * * * \mathrm{p}<0.01, * * \mathrm{p}<0.05, * \mathrm{p}<0.1$ 
Figure 1: Plotted estimates from regression models on productivity differences between foreign and Swedish firms in the manufacturing sector for 28 countries against the management index regressions.
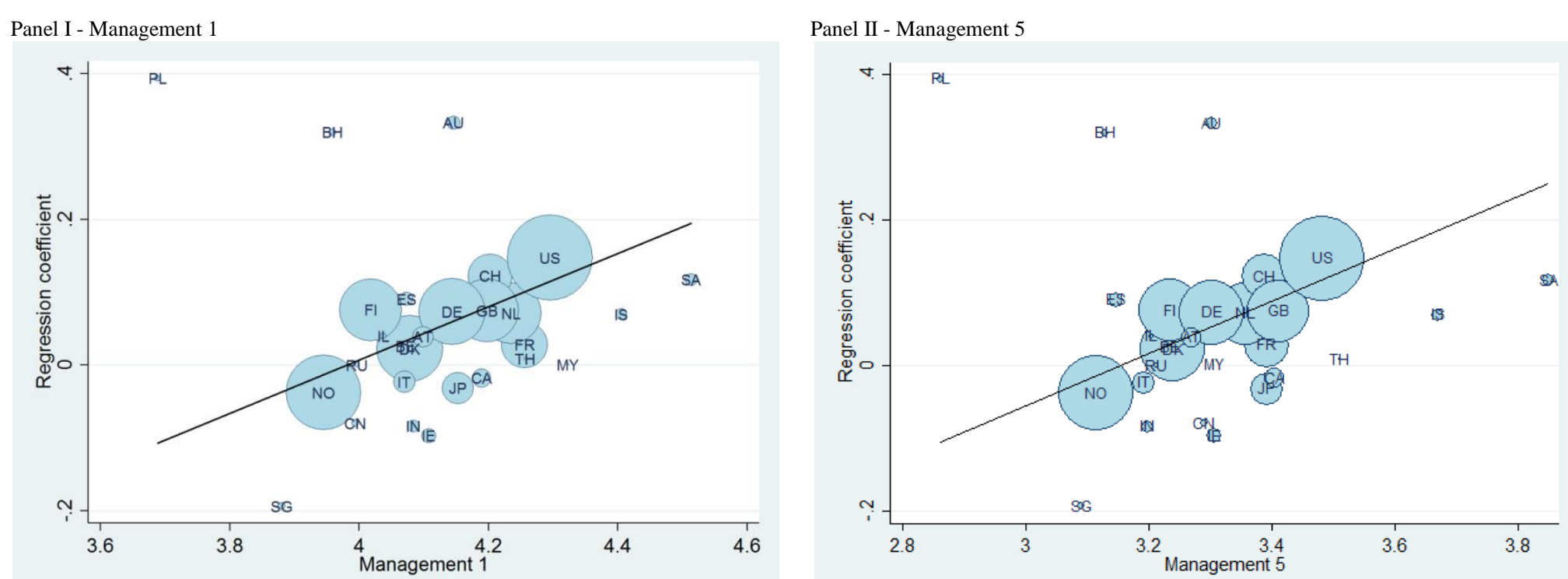

Note: Panel I and II plots the country productivity coefficients from table 3, column 4 against the management 1 (Table 6, column 1) and management 5 (Table 6, column 5) index regressions, respectively. The marker size and fitted line are weighted using average number of observations per year and country for each country. 


\section{Appendix}

\section{Tables}

Table A1a: Definitions and descriptive statistics (means and standard deviations). Firms with at least 10 employees, $1996-2009$.

\begin{tabular}{|c|c|c|c|c|c|c|c|c|c|}
\hline Firm variables: & Definition: & All firms & $\begin{array}{l}\text { All } \\
\text { Swedish } \\
\text { firms }\end{array}$ & $\begin{array}{l}\text { Local } \\
\text { Swedish } \\
\text { firms }\end{array}$ & $\begin{array}{l}\text { Swedish } \\
\text { MNEs }\end{array}$ & $\begin{array}{l}\text { Service } \\
\text { firms }\end{array}$ & $\begin{array}{l}\text { Manufacturing } \\
\text { firms }\end{array}$ & $\begin{array}{l}\text { Foreign firms } \\
\text { ( } 28 \text { countries) }\end{array}$ & Source: \\
\hline \multirow[t]{2}{*}{ Productivity } & Value added per employee (MSEK) & 0.47 & 0.46 & 0.45 & 0.61 & 0.48 & 0.46 & 0.61 & Swedish firm data (SCB) \\
\hline & & $(0.43)$ & $(0.41)$ & $(0.40)$ & $(0.58)$ & $(0.47)$ & $(0.31)$ & $(0.55)$ & \\
\hline \multirow[t]{2}{*}{ Capital intensity } & Capital divided by labor ratio & 0.47 & 0.48 & 0.49 & 0.37 & 0.54 & 0.28 & 0.32 & - \\
\hline & & $(2.81)$ & $(2.88)$ & $(2.91)$ & $(1.85)$ & $(3.38)$ & $(1.00)$ & $(1.88)$ & \\
\hline \multirow[t]{2}{*}{ Firm size } & Number of employees & 58.68 & 49.62 & 39.77 & 360.35 & 51.30 & 86.18 & 141.56 & - \\
\hline & & $(383.14)$ & $(365.27)$ & $(297.70)$ & $(1203.13)$ & $(367.30)$ & $(459.23)$ & $(505.22)$ & \\
\hline \multirow[t]{2}{*}{ Share skill high } & Percentage share of employees with a higher education & 0.22 & 0.21 & 0.21 & 0.30 & 0.28 & 0.15 & 0.34 & - \\
\hline & & $(0.24)$ & $(0.24)$ & $(0.24)$ & $(0.24)$ & $(0.27)$ & $(0.16)$ & $(0.25)$ & \\
\hline
\end{tabular}


Table A1b: Definitions and descriptive statistics (means and standard deviations). Firms with at least 10 employees $2000-2009$, selected countries, manufacturing sector.

\begin{tabular}{|c|c|c|c|c|c|c|}
\hline \multirow[b]{2}{*}{ Management variables: } & \multirow[b]{2}{*}{ Definition: } & \multicolumn{2}{|c|}{10 countries } & \multicolumn{2}{|c|}{28 countries } & \multirow[b]{2}{*}{ Source: } \\
\hline & & Mean: & SD: & Mean: & SD: & \\
\hline Management1 & Index w/o domestic multinationals, controls for year, country and industry effects & 4.11 & 0.13 & 4.14 & 0.12 & World Management Survey \\
\hline Management2 & Index w/o domestic multinationals & 3.20 & 0.11 & 3.21 & 0.12 & - \\
\hline Management 3 & Index on all firms & 3.19 & 0.12 & 3.19 & 0.13 & - \\
\hline Management5 & Index on foreign multinationals, controls for year, country and industry effects & 3.32 & 0.12 & 3.32 & 0.12 & - \\
\hline Management6 & Index on foreign multinationals & 3.21 & 0.10 & 3.21 & 0.12 & - \\
\hline Country variables: & Definition: & Mean: & SD: & Mean: & SD: & Source: \\
\hline Distance & Weighted distance (pop-wt. 10,000 km) & 2.2201 & 0.2692 & 0.2308 & 0.2734 & CEPII distance measure \\
\hline GDP & Gross domestic product (1000 billion ppp USD) & 2.62 & 4.01 & 2.44 & 3.89 & Penn World Table \\
\hline Rule of law & Rule of law estimate & 8.64 & 0.33 & 8.57 & 0.51 & Worldwide Governance Indicators \\
\hline Business freedom & Business freedom & 8.49 & 0.94 & 8.45 & 0.97 & Heritage Foundation \\
\hline Freedom to trade & Freedom of trade & 8.32 & 0.32 & 8.29 & 0.39 & - \\
\hline
\end{tabular}


Table A2: Productivity differences after US acquisitions of other foreign owned firms 1996-2009 (at least 10 employees).

\begin{tabular}{|c|c|c|c|c|c|}
\hline \multirow[b]{3}{*}{ Foreign } & All firms & All firms & All firms & \multirow{2}{*}{$\begin{array}{c}\text { Manu. } \\
(4)\end{array}$} & \multirow{2}{*}{$\begin{array}{c}\text { Service } \\
(5)\end{array}$} \\
\hline & (1) & (2) & (3) & & \\
\hline & $\begin{array}{l}0.066 \\
(0.060)\end{array}$ & & & & \\
\hline Denmark & & $\begin{array}{l}0.111 \\
(0.128)\end{array}$ & $\begin{array}{l}0.097 \\
(0.126)\end{array}$ & $\begin{array}{l}-0.045 \\
(0.166)\end{array}$ & $\begin{array}{l}0.170 \\
(0.176)\end{array}$ \\
\hline UK & & $\begin{array}{l}0.087 * \\
(0.052)\end{array}$ & $\begin{array}{l}0.079 \\
(0.052)\end{array}$ & $\begin{array}{l}0.023 \\
(0.068)\end{array}$ & $\begin{array}{l}0.097 \\
(0.066)\end{array}$ \\
\hline Germany & & $\begin{array}{l}0.037 \\
(0.069)\end{array}$ & $\begin{array}{l}0.015 \\
(0.070)\end{array}$ & $\begin{array}{l}-0.103 * * \\
(0.051)\end{array}$ & $\begin{array}{l}0.040 \\
(0.100)\end{array}$ \\
\hline France & & $\begin{array}{l}0.103 \\
(0.079)\end{array}$ & $\begin{array}{l}0.076 \\
(0.072)\end{array}$ & $\begin{array}{l}0.253 * * * \\
(0.084)\end{array}$ & $\begin{array}{l}-0.014 \\
(0.079)\end{array}$ \\
\hline Norway & & $\begin{array}{l}0.054 \\
(0.040)\end{array}$ & $\begin{array}{l}0.020 \\
(0.046)\end{array}$ & $\begin{array}{l}-0.091 \\
(0.179)\end{array}$ & $\begin{array}{l}0.032 \\
(0.052)\end{array}$ \\
\hline Netherlands & & $\begin{array}{l}0.069 \\
(0.077)\end{array}$ & $\begin{array}{l}0.035 \\
(0.076)\end{array}$ & $\begin{array}{l}0.069 \\
(0.058)\end{array}$ & $\begin{array}{l}0.036 \\
(0.096)\end{array}$ \\
\hline Finland & & $\begin{array}{l}-0.157 \\
(0.099)\end{array}$ & $\begin{array}{l}-0.192 * * \\
(0.094)\end{array}$ & $\begin{array}{l}-0.108 \\
(0.095)\end{array}$ & $\begin{array}{l}0.117 \\
(0.294)\end{array}$ \\
\hline Foreign other & & $\begin{array}{l}-0.048 \\
(0.046)\end{array}$ & $\begin{array}{l}-0.053 \\
(0.044)\end{array}$ & $\begin{array}{l}-0.084 \\
(0.054)\end{array}$ & $\begin{array}{l}0.049 \\
(0.088)\end{array}$ \\
\hline Firm controls & No & No & Yes & Yes & Yes \\
\hline Observations & 2,168 & 2,168 & 2,168 & 744 & 1,406 \\
\hline R-squared & 0.040 & 0.045 & 0.058 & 0.103 & 0.072 \\
\hline $\begin{array}{l}\text { Note: The de } \\
\text { capital per en } \\
\text { "Manu." indic } \\
\text { include intera } \\
\text { show significa }\end{array}$ & $\begin{array}{l}\text { e, variable } i \\
\text { e, logged nu } \\
\text { he manufact } \\
\text { the individua } \\
\text { the } 1 \%\end{array}$ & $\begin{array}{l}\text { ogged value } \\
\text { ber of emp } \\
\text { ng sector, ar } \\
\text { me controls } \\
\text { hd } 10 \% \text { leve }\end{array}$ & $\begin{array}{l}\text { dded per en } \\
\text { ees, and sh } \\
\text { "Service" is } \\
\text { tandard erro } \\
\text { respectively }\end{array}$ & $\begin{array}{l}\text { e. Firm con } \\
\text { skilled wor } \\
\text { rvice sector } \\
\text { clustered by }\end{array}$ & $\begin{array}{l}\text { ls are loggec } \\
\mathrm{s} \text { at the firm } \\
11 \text { regression } \\
\mathrm{m} . * * *, * *\end{array}$ \\
\hline
\end{tabular}


Table A3: Acquisitions of Swedish firms, only acquired firms. Before and after analysis (all available foreign-owned firms)

\begin{tabular}{|c|c|c|c|c|c|c|c|c|c|c|c|c|}
\hline & \multicolumn{6}{|c|}{ All firms } & \multicolumn{6}{|c|}{ Vs. Local firms } \\
\hline & $t-2$ & $t-1$ & $\mathrm{t}$ & $t+1$ & $t+2$ & $>t+2$ & $t-2$ & $t-1$ & $\mathrm{t}$ & $\mathrm{t}+1$ & $t+2$ & $>t+2$ \\
\hline Japan & $\begin{array}{l}-0.140 \\
(0.121)\end{array}$ & $\begin{array}{c}-0.173 * * \\
(0.085)\end{array}$ & $\begin{array}{l}-0.315^{*} \\
(0.181)\end{array}$ & $\begin{array}{l}-0.049 \\
(0.109)\end{array}$ & $\begin{array}{c}0.004 \\
(0.095)\end{array}$ & $\begin{array}{l}-0.159 \\
(0.103)\end{array}$ & $\begin{array}{l}-0.155 \\
(0.145)\end{array}$ & $\begin{array}{c}-0.181^{*} \\
(0.099)\end{array}$ & $\begin{array}{l}-0.310 \\
(0.205)\end{array}$ & $\begin{array}{l}-0.045 \\
(0.125)\end{array}$ & $\begin{array}{c}0.016 \\
(0.111)\end{array}$ & $\begin{array}{l}-0.153 \\
(0.123)\end{array}$ \\
\hline Denmark & $\begin{array}{l}-0.018 \\
(0.023)\end{array}$ & $\begin{array}{l}-0.046^{*} \\
(0.027)\end{array}$ & $\begin{array}{l}-0.001 \\
(0.024)\end{array}$ & $\begin{array}{c}0.018 \\
(0.026)\end{array}$ & $\begin{array}{l}-0.003 \\
(0.032)\end{array}$ & $\begin{array}{l}-0.056^{*} \\
(0.033)\end{array}$ & $\begin{array}{l}-0.033 \\
(0.024)\end{array}$ & $\begin{array}{l}-0.042 \\
(0.027)\end{array}$ & $\begin{array}{l}-0.011 \\
(0.026)\end{array}$ & $\begin{array}{c}0.009 \\
(0.027)\end{array}$ & $\begin{array}{l}-0.026 \\
(0.035)\end{array}$ & $\begin{array}{c}-0.078^{* *} \\
(0.037)\end{array}$ \\
\hline UK & $\begin{array}{c}0.002 \\
(0.031)\end{array}$ & $\begin{array}{c}0.021 \\
(0.028)\end{array}$ & $\begin{array}{l}-0.002 \\
(0.032)\end{array}$ & $\begin{array}{c}0.041 \\
(0.036)\end{array}$ & $\begin{array}{c}0.010 \\
(0.038)\end{array}$ & $\begin{array}{l}-0.023 \\
(0.039)\end{array}$ & $\begin{array}{l}-0.010 \\
(0.032)\end{array}$ & $\begin{array}{c}0.021 \\
(0.030)\end{array}$ & $\begin{array}{l}-0.015 \\
(0.035)\end{array}$ & $\begin{array}{c}0.040 \\
(0.036)\end{array}$ & $\begin{array}{l}-0.007 \\
(0.042)\end{array}$ & $\begin{array}{l}-0.035 \\
(0.041)\end{array}$ \\
\hline Germany & $\begin{array}{l}-0.030 \\
(0.030)\end{array}$ & $\begin{array}{l}-0.023 \\
(0.025)\end{array}$ & $\begin{array}{c}0.026 \\
(0.025)\end{array}$ & $\begin{array}{c}0.017 \\
(0.031)\end{array}$ & $\begin{array}{c}0.011 \\
(0.038)\end{array}$ & $\begin{array}{c}0.008 \\
(0.032)\end{array}$ & $\begin{array}{l}-0.037 \\
(0.034)\end{array}$ & $\begin{array}{l}-0.030 \\
(0.028)\end{array}$ & $\begin{array}{c}0.012 \\
(0.028)\end{array}$ & $\begin{array}{c}0.016 \\
(0.035)\end{array}$ & $\begin{array}{l}-0.005 \\
(0.043)\end{array}$ & $\begin{array}{c}0.001 \\
(0.036)\end{array}$ \\
\hline France & $\begin{array}{l}-0.022 \\
(0.055)\end{array}$ & $\begin{array}{c}0.084 * * \\
(0.041)\end{array}$ & $\begin{array}{c}0.041 \\
(0.048)\end{array}$ & $\begin{array}{c}0.047 \\
(0.052)\end{array}$ & $\begin{array}{c}0.064 \\
(0.083)\end{array}$ & $\begin{array}{c}0.040 \\
(0.059)\end{array}$ & $\begin{array}{l}-0.013 \\
(0.066)\end{array}$ & $\begin{array}{c}0.116 * * \\
(0.047)\end{array}$ & $\begin{array}{c}0.053 \\
(0.055)\end{array}$ & $\begin{array}{c}0.055 \\
(0.059)\end{array}$ & $\begin{array}{c}0.084 \\
(0.096)\end{array}$ & $\begin{array}{c}0.058 \\
(0.066)\end{array}$ \\
\hline Norway & $\begin{array}{l}-0.024 \\
(0.022)\end{array}$ & $\begin{array}{l}-0.040 \\
(0.025)\end{array}$ & $\begin{array}{l}-0.038 \\
(0.033)\end{array}$ & $\begin{array}{l}-0.006 \\
(0.031)\end{array}$ & $\begin{array}{c}0.000 \\
(0.032)\end{array}$ & $\begin{array}{c}0.010 \\
(0.037)\end{array}$ & $\begin{array}{l}-0.036 \\
(0.023)\end{array}$ & $\begin{array}{l}-0.049^{*} \\
(0.026)\end{array}$ & $\begin{array}{l}-0.053 \\
(0.034)\end{array}$ & $\begin{array}{l}-0.023 \\
(0.032)\end{array}$ & $\begin{array}{l}-0.019 \\
(0.034)\end{array}$ & $\begin{array}{l}-0.013 \\
(0.040)\end{array}$ \\
\hline Netherlands & $\begin{array}{l}-0.007 \\
(0.025)\end{array}$ & $\begin{array}{l}-0.056^{*} \\
(0.034)\end{array}$ & $\begin{array}{l}0.051^{*} \\
(0.029)\end{array}$ & $\begin{array}{c}0.022 \\
(0.033)\end{array}$ & $\begin{array}{c}0.021 \\
(0.034)\end{array}$ & $\begin{array}{l}-0.067 * \\
(0.036)\end{array}$ & $\begin{array}{l}-0.015 \\
(0.027)\end{array}$ & $\begin{array}{c}-0.077 * * \\
(0.037)\end{array}$ & $\begin{array}{c}0.036 \\
(0.032)\end{array}$ & $\begin{array}{c}0.011 \\
(0.035)\end{array}$ & $\begin{array}{l}-0.013 \\
(0.036)\end{array}$ & $\begin{array}{c}-0.102 * * \\
(0.040)\end{array}$ \\
\hline Finland & $\begin{array}{c}0.004 \\
(0.028)\end{array}$ & $\begin{array}{c}-0.045 \\
(0.030)\end{array}$ & $\begin{array}{l}-0.038 \\
(0.028)\end{array}$ & $\begin{array}{c}-0.004 \\
(0.033)\end{array}$ & $\begin{array}{c}0.024 \\
(0.039)\end{array}$ & $\begin{array}{c}0.050 \\
(0.038)\end{array}$ & $\begin{array}{c}0.010 \\
(0.032)\end{array}$ & $\begin{array}{l}-0.053 \\
(0.035)\end{array}$ & $\begin{array}{l}-0.034 \\
(0.031)\end{array}$ & $\begin{array}{c}-0.009 \\
(0.040)\end{array}$ & $\begin{array}{c}0.015 \\
(0.045)\end{array}$ & $\begin{array}{c}0.067 \\
(0.045)\end{array}$ \\
\hline Switzerland & $\begin{array}{l}-0.037 \\
(0.037)\end{array}$ & $\begin{array}{c}-0.142 * * * \\
(0.050)\end{array}$ & $\begin{array}{l}-0.058 \\
(0.038)\end{array}$ & $\begin{array}{c}-0.123^{* * *} \\
(0.044)\end{array}$ & $\begin{array}{c}-0.159 * * * \\
(0.049)\end{array}$ & $\begin{array}{c}-0.169 * * * \\
(0.060)\end{array}$ & $\begin{array}{l}-0.049 \\
(0.043)\end{array}$ & $\begin{array}{c}-0.138 * * * \\
(0.050)\end{array}$ & $\begin{array}{c}-0.074 * \\
(0.040)\end{array}$ & $\begin{array}{c}-0.158 * * * \\
(0.042)\end{array}$ & $\begin{array}{c}-0.193 * * * \\
(0.048)\end{array}$ & $\begin{array}{c}-0.200 * * * * \\
(0.063)\end{array}$ \\
\hline Foreign other & $\begin{array}{c}0.023 \\
(0.026) \\
\end{array}$ & $\begin{array}{l}-0.037 \\
(0.032) \\
\end{array}$ & $\begin{array}{l}-0.006 \\
(0.032) \\
\end{array}$ & $\begin{array}{c}-0.004 \\
(0.036) \\
\end{array}$ & $\begin{array}{c}-0.058 \\
(0.041) \\
\end{array}$ & $\begin{array}{l}-0.012 \\
(0.041) \\
\end{array}$ & $\begin{array}{c}0.013 \\
(0.029) \\
\end{array}$ & $\begin{array}{c}-0.059^{*} \\
(0.035) \\
\end{array}$ & $\begin{array}{c}-0.011 \\
(0.033) \\
\end{array}$ & $\begin{array}{l}-0.002 \\
(0.039)\end{array}$ & $\begin{array}{l}-0.072 \\
(0.045)\end{array}$ & $\begin{array}{l}-0.023 \\
(0.044)\end{array}$ \\
\hline Firm Controls & \multicolumn{6}{|c|}{ Yes } & \multicolumn{6}{|c|}{ Yes } \\
\hline $\begin{array}{l}\text { Observations } \\
\text { R-squared }\end{array}$ & \multicolumn{6}{|c|}{$\begin{array}{c}40,487 \\
0.062\end{array}$} & \multicolumn{6}{|c|}{$\begin{array}{c}32,454 \\
0.061\end{array}$} \\
\hline
\end{tabular}

Note: The dependent variable is logged value added per employee. The reference group consists of Swedish firms "All" in columns 1-6 and "Local" (non-multinational domestic firms) in columns 7-12. Firm controls are logged capital per employee, logged number of employees, and share of skilled workers at the firm. All regressions include interacted and individual time controls. The table shows estimated coefficients from regressions with specific time period dummies. Acquisition takes the value of 1 in the acquisition period and thereafter; 0 before. Acquisition $\mathrm{t}-2$ takes the value of 1 two years prior to the acquisition; 0 otherwise. The other acquisition $\mathrm{t}+/-$ variables are defined accordingly. Standard errors are clustered by firm. $* * *$, **, * show significance at the $1 \%, 5 \%$, and $10 \%$ levels, respectively 
Table A4: Management and productivity, 2000-2009 (at least 10 employees).

Impact of different sub-index.

\begin{tabular}{|c|c|c|c|c|c|c|}
\hline \multirow[b]{3}{*}{ Monitor } & \multicolumn{3}{|c|}{ Management 1} & \multicolumn{3}{|c|}{ Management 5} \\
\hline & $(1)$ & $(2)$ & (3) & (4) & (5) & (6) \\
\hline & $\begin{array}{l}0.045 \\
(0.033)\end{array}$ & & & $\begin{array}{l}0.073^{* *} \\
(0.033)\end{array}$ & & \\
\hline Incentives & & $\begin{array}{l}0.060^{*} \\
(0.033)\end{array}$ & & & $\begin{array}{l}0.069^{* *} \\
(0.032)\end{array}$ & \\
\hline Target & & & $\begin{array}{l}0.035 \\
(0.026) \\
\end{array}$ & & & $\begin{array}{l}0.040 \\
(0.024) \\
\end{array}$ \\
\hline $\log (\mathrm{K} / \mathrm{L})$ & $\begin{array}{l}0.116^{* * *} \\
(0.011)\end{array}$ & $\begin{array}{l}0.117 \text { *** } \\
(0.011)\end{array}$ & $\begin{array}{l}0.117 * * * \\
(0.011)\end{array}$ & $\begin{array}{l}0.117 * * * \\
(0.011)\end{array}$ & $\begin{array}{l}0.118 * * * \\
(0.011)\end{array}$ & $\begin{array}{l}0.117 \text { *** } \\
(0.011)\end{array}$ \\
\hline $\log (\mathrm{L})$ & $\begin{array}{l}0.026^{* *} \\
(0.012)\end{array}$ & $\begin{array}{l}0.025^{* *} \\
(0.012)\end{array}$ & $\begin{array}{l}0.026 * * \\
(0.012)\end{array}$ & $\begin{array}{l}0.025^{* *} \\
(0.012)\end{array}$ & $\begin{array}{l}0.025 * * \\
(0.012)\end{array}$ & $\begin{array}{l}0.025^{* *} \\
(0.012)\end{array}$ \\
\hline Share skill high & $\begin{array}{l}0.689 * * * \\
(0.096)\end{array}$ & $\begin{array}{l}0.696 \text { *** } \\
(0.093)\end{array}$ & $\begin{array}{l}0.695 \text { *** } \\
(0.093) \\
\end{array}$ & $\begin{array}{l}0.687 * * * \\
(0.095)\end{array}$ & $\begin{array}{l}0.697 * * * \\
(0.093) \\
\end{array}$ & $\begin{array}{l}0.697 * * * \\
(0.092) \\
\end{array}$ \\
\hline Country controls & Yes & Yes & Yes & Yes & Yes & Yes \\
\hline Observations & 8,813 & 8,813 & 8,813 & 8,813 & 8,813 & 8,813 \\
\hline R-squared & 0.166 & 0.166 & 0.165 & 0.167 & 0.166 & 0.165 \\
\hline $\begin{array}{l}\text { Note: The depen } \\
\text { Management } 1 \text { - w } \\
\text { industry fixed eff } \\
\text { country effect inte } \\
\text { number of employ } \\
\text { population weight } \\
\text { Foundation measu } \\
\text { industry controls a } \\
\text { at the } 1 \%, 5 \% \text {, and }\end{array}$ & $\begin{array}{l}\text { nt variable } \\
\text { domestic } m \\
\text { ts and Man } \\
\text { ated and in } \\
\text { es, and shar } \\
\text { distance } m \\
\text { s of econom } \\
\text { well as clus } \\
0 \% \text { levels, } 1\end{array}$ & $\begin{array}{l}\text { is logged } \\
\text { iltinationals } \\
\text { gement5 - } \\
\text { ustry effect } \\
\text { of skilled } \\
\text { easure, WG } \\
\text { c freedom. } \\
\text { ered standar }\end{array}$ & $\begin{array}{l}\text { value addec } \\
\text { controls for } \\
\text { n the samp } \\
\text { Firm contr } \\
\text { vorkers at f } \\
\text { level of leg } \\
\text { ll regression } \\
\text { errors at the }\end{array}$ & $\begin{array}{l}\text { omploye } \\
\text { and countr } \\
\text { f foreign } \mathrm{M} \\
\text { are logged c } \\
\text { Country co } \\
\text { stitutions " } \\
\text { clude intera } \\
\text { intry level. }\end{array}$ & $\begin{array}{l}\text { Sub-inde } \\
\text { fixed effec } \\
\text { NEs, contro } \\
\text { pital per en } \\
\text { ttrols inclu } \\
\text { ule of Law } \\
\text { ted and indi } \\
* *, * *, * \text { sh }\end{array}$ & $\begin{array}{l}\text { according to } \\
\text { integrated and } \\
\text { s for year an } \\
\text { ployee, loggec } \\
\text { GDP, CEPI } \\
\text { and Heritag } \\
\text { idual time and } \\
\text { w significance }\end{array}$ \\
\hline
\end{tabular}




\section{Figures}

Figure A1: Foreign ownership and foreign acquisitions compared to Swedish local firms and MNEs, 1996-2009. Dependent variable: logged value added per employee (at least 10 employees). Point estimates and 95\% confidence intervals.

Panel I - Productivity differences between foreign and Swedish firms (Visual display of Table 3, column 3).

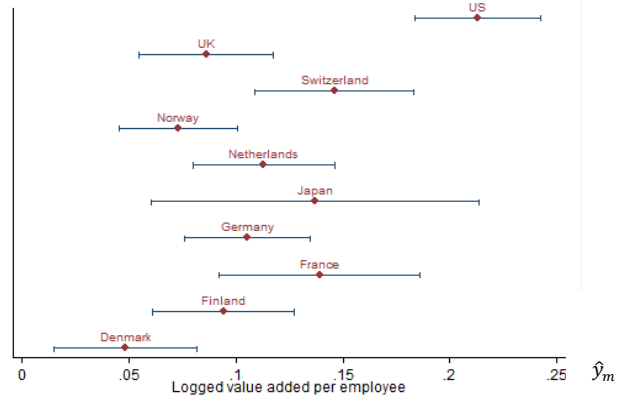

Panel IV - Productivity differences after acquisitions of Swedish firms by foreign firms (Visual display of Table 5 ,

column 3. Point estimates of Equation (2) with $95 \%$ confidence intervals).

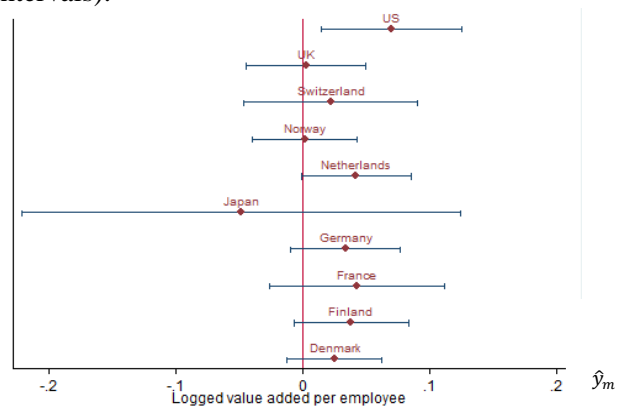

Panel VII - Productivity differences between foreig Greenfields and Swedish firms (Visual display of Table 4, column 3).

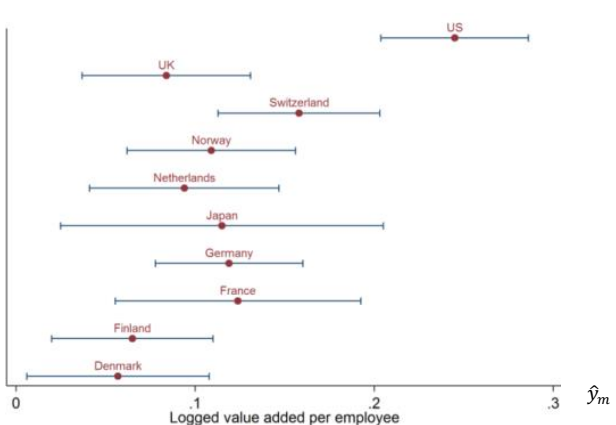

Panel II - Productivity differences between foreign firms and Swedish local firms (Visual display of Table 3, column 6 )

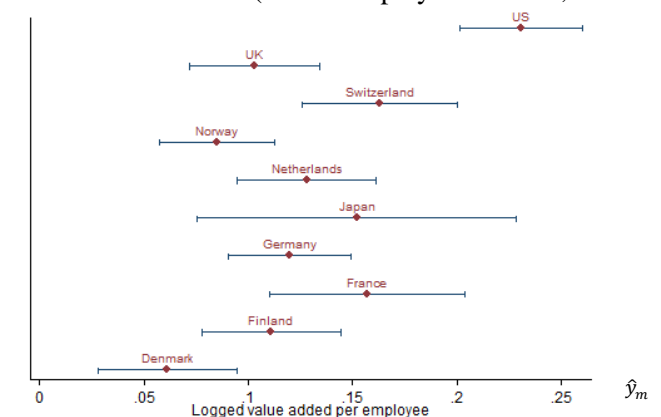

Panel V - Productivity differences after acquisitions of Swedish local firms by foreign firms (Visual display of Table 5, column

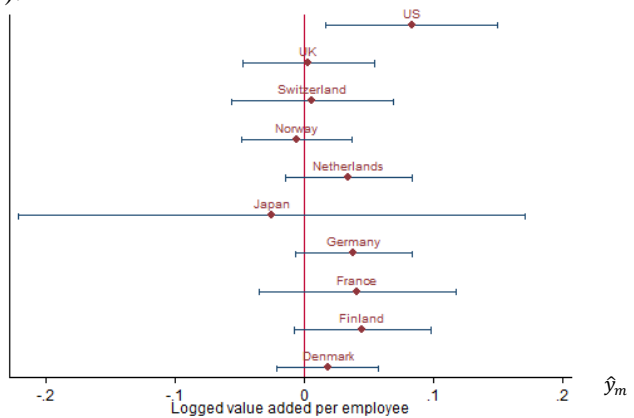

Panel VIII - Productivity differences between foreign Greenfields and Swedish local firms (Visual display of Table 4 , column 6)

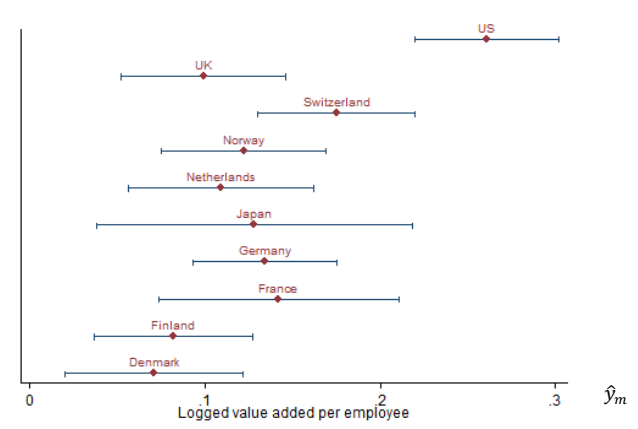

Panel III - Productivity differences between foreign firm and Swedish MNEs (Visual display of Table 3, column 7).

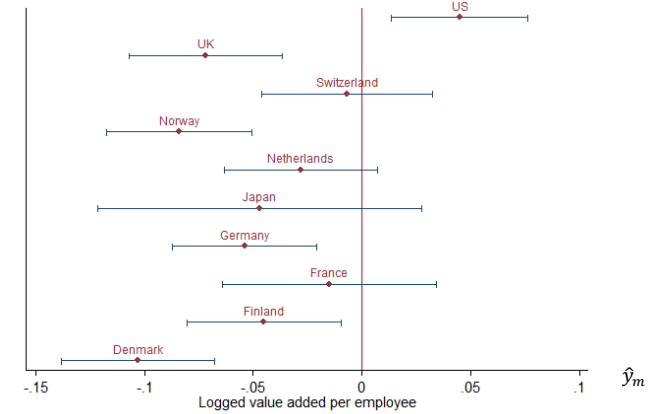

Panel VI - Productivity differences after acquisitions of Swedish MNEs by foreign firms (Visual display of Table 5 , column 7).

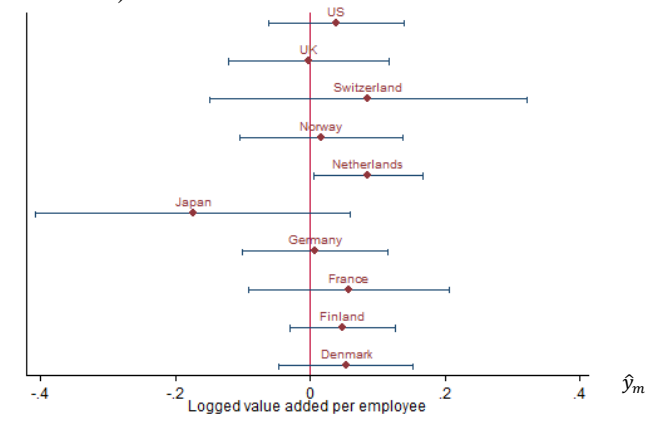

Panel IX - Productivity differences between foreign Greenfields and Swedish MNEs (Visual display of Table 4 column 7)

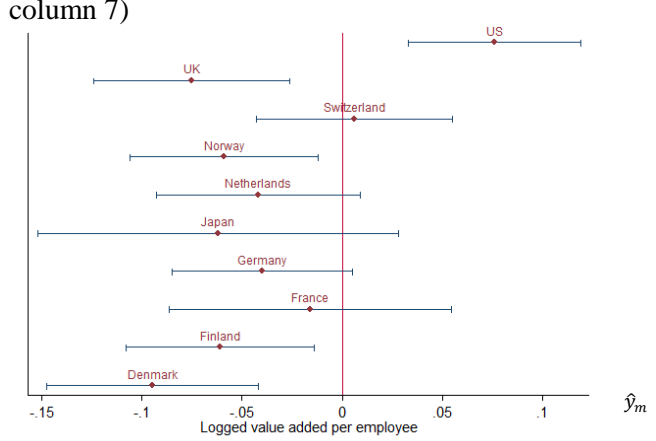




\section{Online Appendix}

\section{Tables}

Table OA1.1: Wald tests of the estimates from Table 3 - Reference group: Swedish firms; All, Manufacturing, Service, MNEs, Local.

\begin{tabular}{|c|c|c|c|c|c|c|c|c|c|}
\hline All firms & Japan & US & Denmark & UK & Germany & France & Norway & NL & Finland \\
\hline US & 0.06 & & & & & & & & \\
\hline Denmark & 0.03 & 0.00 & & & & & & & \\
\hline UK & 0.22 & 0.00 & 0.09 & & & & & & \\
\hline Germany & 0.44 & 0.00 & 0.01 & 0.37 & & & & & \\
\hline France & 0.96 & 0.01 & 0.00 & 0.06 & 0.23 & & & & \\
\hline Norway & 0.12 & 0.00 & 0.24 & 0.54 & 0.12 & 0.02 & & & \\
\hline NL & 0.57 & 0.00 & 0.01 & 0.22 & 0.71 & 0.37 & 0.06 & & \\
\hline Finland & 0.31 & 0.00 & 0.05 & 0.71 & 0.62 & 0.12 & 0.33 & 0.40 & \\
\hline Switzerland & 0.84 & 0.00 & 0.00 & 0.01 & 0.08 & 0.82 & 0.00 & 0.18 & 0.03 \\
\hline Manu. firms & Japan & US & Denmark & UK & Germany & France & Norway & NL & Finland \\
\hline US & 0.01 & & & & & & & & \\
\hline Denmark & 0.42 & 0.00 & & & & & & & \\
\hline UK & 0.12 & 0.05 & 0.16 & & & & & & \\
\hline Germany & 0.12 & 0.06 & 0.19 & 0.97 & & & & & \\
\hline France & 0.41 & 0.01 & 0.89 & 0.33 & 0.35 & & & & \\
\hline Norway & 0.93 & 0.00 & 0.07 & 0.00 & 0.00 & 0.13 & & & \\
\hline NL & 0.12 & 0.04 & 0.16 & 0.94 & 0.97 & 0.34 & 0.00 & & \\
\hline Finland & 0.10 & 0.04 & 0.11 & 0.97 & 0.94 & 0.28 & 0.00 & 0.89 & \\
\hline Switzerland & 0.02 & 0.53 & 0.01 & 0.22 & 0.23 & 0.05 & 0.00 & 0.16 & 0.20 \\
\hline Service firms & Japan & US & Denmark & UK & Germany & France & Norway & NL & Finland \\
\hline US & 0.20 & & & & & & & & \\
\hline Denmark & 0.01 & 0.00 & & & & & & & \\
\hline UK & 0.06 & 0.00 & 0.17 & & & & & & \\
\hline Germany & 0.17 & 0.00 & 0.02 & 0.34 & & & & & \\
\hline France & 0.82 & 0.17 & 0.00 & 0.00 & 0.03 & & & & \\
\hline Norway & 0.18 & 0.00 & 0.02 & 0.31 & 0.96 & 0.03 & & & \\
\hline NL & 0.28 & 0.00 & 0.01 & 0.20 & 0.67 & 0.08 & 0.70 & & \\
\hline Finland & 0.10 & 0.00 & 0.17 & 0.84 & 0.55 & 0.02 & 0.52 & 0.35 & \\
\hline Switzerland & 0.64 & 0.01 & 0.00 & 0.03 & 0.18 & 0.37 & 0.19 & 0.37 & 0.09 \\
\hline MNE firms & Japan & US & Denmark & UK & Germany & France & Norway & NL & Finland \\
\hline US & 0.05 & & & & & & & & \\
\hline Denmark & 0.03 & 0.00 & & & & & & & \\
\hline UK & 0.24 & 0.00 & 0.06 & & & & & & \\
\hline Germany & 0.45 & 0.00 & 0.01 & 0.41 & & & & & \\
\hline France & 0.90 & 0.01 & 0.00 & 0.06 & 0.19 & & & & \\
\hline Norway & 0.11 & 0.00 & 0.26 & 0.40 & 0.09 & 0.01 & & & \\
\hline NL & 0.58 & 0.00 & 0.00 & 0.25 & 0.71 & 0.32 & 0.05 & & \\
\hline Finland & 0.34 & 0.00 & 0.03 & 0.69 & 0.70 & 0.12 & 0.22 & 0.46 & \\
\hline Switzerland & 0.79 & 0.00 & 0.00 & 0.01 & 0.07 & 0.85 & 0.00 & 0.16 & 0.04 \\
\hline Local firms & Japan & US & Denmark & UK & Germany & France & Norway & NL & Finland \\
\hline US & 0.02 & & & & & & & & \\
\hline Denmark & 0.17 & 0.00 & & & & & & & \\
\hline UK & 0.53 & 0.00 & 0.17 & & & & & & \\
\hline Germany & 0.85 & 0.00 & 0.03 & 0.40 & & & & & \\
\hline France & 0.47 & 0.03 & 0.00 & 0.05 & 0.16 & & & & \\
\hline Norway & 0.35 & 0.00 & 0.37 & 0.57 & 0.15 & 0.01 & & & \\
\hline NL & 0.65 & 0.00 & 0.00 & 0.05 & 0.24 & 0.64 & 0.01 & & \\
\hline Finland & 0.96 & 0.00 & 0.01 & 0.22 & 0.67 & 0.31 & 0.07 & 0.47 & \\
\hline Switzerland & 0.34 & 0.03 & 0.00 & 0.01 & 0.05 & 0.80 & 0.00 & 0.39 & 0.13 \\
\hline
\end{tabular}

\section{Note:}

Numbers in red indicate significant values, i.e., that the coefficients are significantly different from another at the $10 \%$ level or lower. 
Table OA1.2: Wald tests of the estimates from Table 4 (greenfields) - Reference group: Swedish firms; All, Manufacturing, Service, MNEs, Local.

\begin{tabular}{|c|c|c|c|c|c|c|c|c|c|}
\hline All firms & Japan & US & Denmark & UK & Germany & France & Norway & NL & Finland \\
\hline US & 0.01 & & & & & & & & \\
\hline Denmark & 0.27 & 0.00 & & & & & & & \\
\hline UK & 0.55 & 0.00 & 0.45 & & & & & & \\
\hline Germany & 0.93 & 0.00 & 0.06 & 0.27 & & & & & \\
\hline France & 0.88 & 0.00 & 0.13 & 0.35 & 0.92 & & & & \\
\hline Norway & 0.90 & 0.00 & 0.15 & 0.47 & 0.74 & 0.73 & & & \\
\hline NL & 0.68 & 0.00 & 0.33 & 0.79 & 0.44 & 0.49 & 0.67 & & \\
\hline Finland & 0.32 & 0.00 & 0.84 & 0.55 & 0.08 & 0.15 & 0.18 & 0.40 & \\
\hline Switzerland & 0.40 & 0.00 & 0.00 & 0.02 & 0.20 & 0.40 & 0.13 & 0.06 & 0.00 \\
\hline Manu. firms & Japan & US & Denmark & UK & Germany & France & Norway & NL & Finland \\
\hline US & 0.04 & & & & & & & & \\
\hline Denmark & 0.85 & 0.02 & & & & & & & \\
\hline UK & 0.94 & 0.00 & 0.86 & & & & & & \\
\hline Germany & 0.79 & 0.02 & 0.92 & 0.77 & & & & & \\
\hline France & 0.81 & 0.01 & 0.61 & 0.67 & 0.54 & & & & \\
\hline Norway & 0.57 & 0.00 & 0.32 & 0.29 & 0.25 & 0.72 & & & \\
\hline NL & 0.72 & 0.01 & 0.85 & 0.66 & 0.93 & 0.45 & 0.14 & & \\
\hline Finland & 0.78 & 0.00 & 0.52 & 0.55 & 0.43 & 0.99 & 0.58 & 0.29 & \\
\hline Switzerland & 0.30 & 0.09 & 0.30 & 0.12 & 0.34 & 0.11 & 0.01 & 0.31 & 0.02 \\
\hline Service firms & Japan & US & Denmark & UK & Germany & France & Norway & NL & Finland \\
\hline US & 0.03 & & & & & & & & \\
\hline Denmark & 0.17 & 0.00 & & & & & & & \\
\hline UK & 0.52 & 0.00 & 0.32 & & & & & & \\
\hline Germany & 0.98 & 0.00 & 0.03 & 0.30 & & & & & \\
\hline France & 0.43 & 0.14 & 0.01 & 0.08 & 0.31 & & & & \\
\hline Norway & 0.57 & 0.03 & 0.01 & 0.10 & 0.43 & 0.74 & & & \\
\hline NL & 0.59 & 0.00 & 0.30 & 0.90 & 0.42 & 0.12 & 0.16 & & \\
\hline Finland & 0.43 & 0.00 & 0.55 & 0.80 & 0.26 & 0.08 & 0.10 & 0.73 & \\
\hline Switzerland & 0.45 & 0.04 & 0.00 & 0.05 & 0.28 & 0.89 & 0.82 & 0.09 & 0.06 \\
\hline MNE firms & Japan & US & Denmark & UK & Germany & France & Norway & NL & Finland \\
\hline US & 0.01 & & & & & & & & \\
\hline Denmark & 0.28 & 0.00 & & & & & & & \\
\hline UK & 0.57 & 0.00 & 0.43 & & & & & & \\
\hline Germany & 0.91 & 0.00 & 0.06 & 0.27 & & & & & \\
\hline France & 0.82 & 0.00 & 0.10 & 0.31 & 0.85 & & & & \\
\hline Norway & 0.89 & 0.00 & 0.16 & 0.52 & 0.69 & 0.63 & & & \\
\hline NL & 0.71 & 0.00 & 0.31 & 0.77 & 0.46 & 0.46 & 0.74 & & \\
\hline Finland & 0.36 & 0.00 & 0.76 & 0.60 & 0.09 & 0.15 & 0.23 & 0.43 & \\
\hline Switzerland & 0.36 & 0.00 & 0.00 & 0.02 & 0.18 & 0.41 & 0.10 & 0.06 & 0.00 \\
\hline Local firms & Japan & US & Denmark & UK & Germany & France & Norway & NL & Finland \\
\hline US & 0.00 & & & & & & & & \\
\hline Denmark & 0.52 & 0.00 & & & & & & & \\
\hline UK & 0.78 & 0.00 & 0.60 & & & & & & \\
\hline Germany & 0.67 & 0.00 & 0.10 & 0.27 & & & & & \\
\hline France & 0.43 & 0.02 & 0.07 & 0.16 & 0.56 & & & & \\
\hline Norway & 0.99 & 0.00 & 0.32 & 0.66 & 0.52 & 0.30 & & & \\
\hline NL & 0.74 & 0.00 & 0.17 & 0.37 & 0.91 & 0.53 & 0.63 & & \\
\hline Finland & 1.00 & 0.00 & 0.34 & 0.67 & 0.50 & 0.29 & 0.98 & 0.62 & \\
\hline Switzerland & 0.17 & 0.02 & 0.00 & 0.01 & 0.12 & 0.57 & 0.04 & 0.14 & 0.04 \\
\hline
\end{tabular}


Table A1.3: Wald tests of the estimates from Table 5 (acquisitions) - Reference group: Swedish firms; All, Manufacturing, Service, MNEs, Local.

\begin{tabular}{|c|c|c|c|c|c|c|c|c|c|}
\hline All firms & Japan & US & Denmark & UK & Germany & France & Norway & NL & Finland \\
\hline US & 0.20 & & & & & & & & \\
\hline Denmark & 0.42 & 0.19 & & & & & & & \\
\hline UK & 0.57 & 0.08 & 0.48 & & & & & & \\
\hline Germany & 0.37 & 0.31 & 0.76 & 0.35 & & & & & \\
\hline France & 0.34 & 0.55 & 0.65 & 0.35 & 0.82 & & & & \\
\hline Norway & 0.58 & 0.05 & 0.42 & 0.97 & 0.29 & 0.32 & & & \\
\hline NL & 0.32 & 0.45 & 0.54 & 0.23 & 0.77 & 0.99 & 0.18 & & \\
\hline Finland & 0.35 & 0.38 & 0.66 & 0.30 & 0.90 & 0.90 & 0.25 & 0.88 & \\
\hline Switzerland & 0.46 & 0.29 & 0.93 & 0.67 & 0.77 & 0.67 & 0.64 & 0.61 & 0.70 \\
\hline Manu. firms & Japan & US & Denmark & UK & Germany & France & Norway & NL & Finland \\
\hline US & 0.91 & & & & & & & & \\
\hline Denmark & 0.90 & 0.52 & & & & & & & \\
\hline UK & 0.42 & 0.04 & 0.08 & & & & & & \\
\hline Germany & 0.91 & 0.61 & 0.97 & 0.12 & & & & & \\
\hline France & 0.51 & 0.24 & 0.37 & 0.97 & 0.38 & & & & \\
\hline Norway & 0.24 & 0.00 & 0.01 & 0.42 & 0.02 & 0.61 & & & \\
\hline NL & 0.84 & 0.44 & 0.82 & 0.16 & 0.82 & 0.44 & 0.02 & & \\
\hline Finland & 0.66 & 0.16 & 0.34 & 0.35 & 0.41 & 0.64 & 0.06 & 0.54 & \\
\hline Switzerland & 0.70 & 0.34 & 0.57 & 0.48 & 0.58 & 0.66 & 0.16 & 0.70 & 0.96 \\
\hline Service firms & Japan & US & Denmark & UK & Germany & France & Norway & NL & Finland \\
\hline US & 0.25 & & & & & & & & \\
\hline Denmark & 0.43 & 0.32 & & & & & & & \\
\hline UK & 0.46 & 0.30 & 0.92 & & & & & & \\
\hline Germany & 0.37 & 0.50 & 0.73 & 0.67 & & & & & \\
\hline France & 0.26 & 0.95 & 0.33 & 0.31 & 0.52 & & & & \\
\hline Norway & 0.42 & 0.35 & 0.94 & 0.86 & 0.78 & 0.36 & & & \\
\hline NL & 0.28 & 0.83 & 0.36 & 0.33 & 0.58 & 0.88 & 0.40 & & \\
\hline Finland & 0.19 & 0.74 & 0.15 & 0.14 & 0.27 & 0.68 & 0.17 & 0.54 & \\
\hline Switzerland & 0.31 & 0.83 & 0.52 & 0.48 & 0.70 & 0.87 & 0.55 & 0.96 & 0.59 \\
\hline MNE firms & Japan & US & Denmark & UK & Germany & France & Norway & NL & Finland \\
\hline US & 0.31 & & & & & & & & \\
\hline Denmark & 0.67 & 0.10 & & & & & & & \\
\hline UK & 0.78 & 0.06 & 0.66 & & & & & & \\
\hline Germany & 0.54 & 0.28 & 0.51 & 0.32 & & & & & \\
\hline France & 0.54 & 0.43 & 0.59 & 0.42 & 0.94 & & & & \\
\hline Norway & 0.85 & 0.03 & 0.43 & 0.79 & 0.17 & 0.29 & & & \\
\hline NL & 0.56 & 0.25 & 0.61 & 0.39 & 0.92 & 0.88 & 0.22 & & \\
\hline Finland & 0.50 & 0.39 & 0.43 & 0.27 & 0.84 & 0.94 & 0.15 & 0.78 & \\
\hline Switzerland & 0.76 & 0.10 & 0.75 & 0.94 & 0.42 & 0.48 & 0.75 & 0.48 & 0.35 \\
\hline Local firms & Japan & US & Denmark & UK & Germany & France & Norway & NL & Finland \\
\hline US & 0.09 & & & & & & & & \\
\hline Denmark & 0.08 & 0.88 & & & & & & & \\
\hline UK & 0.20 & 0.57 & 0.49 & & & & & & \\
\hline Germany & 0.16 & 0.63 & 0.52 & 0.91 & & & & & \\
\hline France & 0.10 & 0.87 & 0.96 & 0.54 & 0.58 & & & & \\
\hline Norway & 0.15 & 0.75 & 0.66 & 0.83 & 0.91 & 0.68 & & & \\
\hline NL & 0.04 & 0.52 & 0.61 & 0.23 & 0.24 & 0.74 & 0.35 & & \\
\hline Finland & 0.07 & 0.94 & 0.93 & 0.49 & 0.53 & 0.91 & 0.67 & 0.51 & \\
\hline Switzerland & 0.12 & 0.74 & 0.80 & 0.51 & 0.54 & 0.84 & 0.61 & 1.00 & 0.76 \\
\hline
\end{tabular}

Note:

Numbers in red indicate significant values, i.e., that the coefficients are significantly different from another at the $10 \%$ level or lower. 
Table 3 with alternative restrictions and number of countries

Table 0A3.1: Productivity differences between foreign and Swedish firms, 1996-2009 (at least 10 employees). No restrictions on switchers.

\begin{tabular}{|c|c|c|c|c|c|c|c|c|c|c|}
\hline & $\begin{array}{c}\text { All firms } \\
\text { (1) }\end{array}$ & $\begin{array}{c}\text { All firms } \\
\text { (2) }\end{array}$ & $\begin{array}{c}\text { All firms } \\
\text { (3) }\end{array}$ & $\begin{array}{l}\text { Manu. } \\
(4)\end{array}$ & $\begin{array}{c}\text { Service } \\
(5)\end{array}$ & $\begin{array}{c}\text { Local firms } \\
(6)\end{array}$ & $\begin{array}{c}\text { MNE } \\
(7)\end{array}$ & $\begin{array}{c}\text { All firms } \\
(8)\end{array}$ & $\begin{array}{c}\text { Manu. } \\
(9)\end{array}$ & $\begin{array}{c}\text { Service } \\
(10)\end{array}$ \\
\hline Foreign & $\begin{array}{l}0.177^{* * * *} \\
(0.006) \\
\end{array}$ & & & & & & & & & \\
\hline Japan & & $\begin{array}{c}0.215 * * * \\
(0.044)\end{array}$ & $\begin{array}{c}0.136^{* * * *} \\
(0.039)\end{array}$ & $\begin{array}{l}-0.018 \\
(0.063)\end{array}$ & $\begin{array}{c}0.177 * * * \\
(0.044)\end{array}$ & $\begin{array}{c}0.151 * * * \\
(0.039)\end{array}$ & $\begin{array}{l}-0.047 \\
(0.038)\end{array}$ & $\begin{array}{c}0.150 * * * \\
(0.039)\end{array}$ & $\begin{array}{c}0.012 \\
(0.064)\end{array}$ & $\begin{array}{c}0.188 * * * \\
(0.044)\end{array}$ \\
\hline US & & $\begin{array}{c}0.304 * * * \\
(0.016)\end{array}$ & $\begin{array}{c}0.213 * * * \\
(0.014)\end{array}$ & $\begin{array}{c}0.163 * * * \\
(0.028)\end{array}$ & $\begin{array}{c}0.237 * * * \\
(0.017)\end{array}$ & $\begin{array}{c}0.231 * * * \\
(0.014)\end{array}$ & $\begin{array}{c}0.044 * * * \\
(0.016)\end{array}$ & $\begin{array}{c}0.230 * * * \\
(0.014)\end{array}$ & $\begin{array}{c}0.197 * * * \\
(0.028)\end{array}$ & $\begin{array}{c}0.249 * * * \\
(0.017)\end{array}$ \\
\hline Denmark & & $\begin{array}{c}0.081 * * * \\
(0.018)\end{array}$ & $\begin{array}{c}0.044 * * * \\
(0.017)\end{array}$ & $\begin{array}{c}0.038 \\
(0.025)\end{array}$ & $\begin{array}{c}0.045^{* *} \\
(0.021)\end{array}$ & $\begin{array}{c}0.057 * * * \\
(0.017)\end{array}$ & $\begin{array}{c}-0.108 * * * \\
(0.018)\end{array}$ & $\begin{array}{c}0.056 * * * \\
(0.017)\end{array}$ & $\begin{array}{c}0.061 * * \\
(0.025)\end{array}$ & $\begin{array}{c}0.055^{* * * *} \\
(0.021)\end{array}$ \\
\hline UK & & $\begin{array}{c}0.158 * * * \\
(0.017)\end{array}$ & $\begin{array}{c}0.084 * * * \\
(0.015)\end{array}$ & $\begin{array}{c}0.087 * * * \\
(0.027)\end{array}$ & $\begin{array}{c}0.087 * * * \\
(0.019)\end{array}$ & $\begin{array}{c}0.101 * * * \\
(0.015)\end{array}$ & $\begin{array}{c}-0.075 * * * \\
(0.018)\end{array}$ & $\begin{array}{c}0.100 * * * \\
(0.015)\end{array}$ & $\begin{array}{c}0.120 * * * \\
(0.027)\end{array}$ & $\begin{array}{c}0.099 * * * \\
(0.019)\end{array}$ \\
\hline Germany & & $\begin{array}{c}0.191 * * * \\
(0.016)\end{array}$ & $\begin{array}{c}0.105 * * * \\
(0.015)\end{array}$ & $\begin{array}{c}0.089 * * * \\
(0.029)\end{array}$ & $\begin{array}{c}0.110 * * * \\
(0.019)\end{array}$ & $\begin{array}{c}0.120 * * * \\
(0.015)\end{array}$ & $\begin{array}{c}-0.056 * * * \\
(0.017)\end{array}$ & $\begin{array}{c}0.119 * * * \\
(0.015)\end{array}$ & $\begin{array}{c}0.115^{* * *} \\
(0.029)\end{array}$ & $\begin{array}{c}0.122 * * * \\
(0.019)\end{array}$ \\
\hline France & & $\begin{array}{c}0.207 * * * \\
(0.026)\end{array}$ & $\begin{array}{c}0.144 * * * \\
(0.025)\end{array}$ & $\begin{array}{c}0.064 \\
(0.043)\end{array}$ & $\begin{array}{c}0.190 * * * \\
(0.031)\end{array}$ & $\begin{array}{c}0.162 * * * \\
(0.025)\end{array}$ & $\begin{array}{l}-0.010 \\
(0.026)\end{array}$ & $\begin{array}{c}0.161 * * * \\
(0.025)\end{array}$ & $\begin{array}{c}0.098 * * \\
(0.043)\end{array}$ & $\begin{array}{c}0.203 * * * \\
(0.031)\end{array}$ \\
\hline Norway & & $\begin{array}{c}0.101 * * * \\
(0.015)\end{array}$ & $\begin{array}{c}0.070 * * * \\
(0.014)\end{array}$ & $\begin{array}{l}-0.022 \\
(0.022)\end{array}$ & $\begin{array}{c}0.109 * * * \\
(0.018)\end{array}$ & $\begin{array}{c}0.082 * * * \\
(0.014)\end{array}$ & $\begin{array}{c}-0.087 * * * \\
(0.016)\end{array}$ & $\begin{array}{c}0.082 * * * \\
(0.014)\end{array}$ & $\begin{array}{c}0.001 \\
(0.023)\end{array}$ & $\begin{array}{c}0.118 * * * \\
(0.018)\end{array}$ \\
\hline Netherlands & & $\begin{array}{c}0.179 * * * \\
(0.019)\end{array}$ & $\begin{array}{c}0.108 * * * \\
(0.016)\end{array}$ & $\begin{array}{c}0.091 * * * \\
(0.025)\end{array}$ & $\begin{array}{c}0.116^{* * * *} \\
(0.021)\end{array}$ & $\begin{array}{c}0.123 * * * \\
(0.017)\end{array}$ & $\begin{array}{l}-0.029 \\
(0.018)\end{array}$ & $\begin{array}{c}0.122 * * * \\
(0.017)\end{array}$ & $\begin{array}{c}0.120 * * * \\
(0.026)\end{array}$ & $\begin{array}{c}0.126 * * * \\
(0.021)\end{array}$ \\
\hline Finland & & $\begin{array}{c}0.142 * * * \\
(0.018)\end{array}$ & $\begin{array}{c}0.095 * * * \\
(0.016)\end{array}$ & $\begin{array}{c}0.091 * * * \\
(0.022)\end{array}$ & $\begin{array}{c}0.094 * * * \\
(0.025)\end{array}$ & $\begin{array}{c}0.113 * * * \\
(0.016)\end{array}$ & $\begin{array}{c}-0.045^{* *} \\
(0.018)\end{array}$ & $\begin{array}{c}0.113 * * * \\
(0.016)\end{array}$ & $\begin{array}{c}0.123 * * * \\
(0.023)\end{array}$ & $\begin{array}{c}0.105^{* * *} \\
(0.025)\end{array}$ \\
\hline Switzerland & & $\begin{array}{c}0.222 * * * \\
(0.022)\end{array}$ & $\begin{array}{c}0.144 * * * \\
(0.018)\end{array}$ & $\begin{array}{c}0.136 * * * \\
(0.029)\end{array}$ & $\begin{array}{c}0.153 * * * \\
(0.025)\end{array}$ & $\begin{array}{c}0.161 * * * \\
(0.018)\end{array}$ & $\begin{array}{l}-0.010 \\
(0.020)\end{array}$ & $\begin{array}{c}0.161 * * * \\
(0.018)\end{array}$ & $\begin{array}{c}0.170 * * * \\
(0.029)\end{array}$ & $\begin{array}{c}0.164 * * * \\
(0.025)\end{array}$ \\
\hline $\begin{array}{l}\text { Foreign } \\
\text { other }\end{array}$ & & $\begin{array}{c}0.143 * * * \\
(0.019)\end{array}$ & $\begin{array}{c}0.074 * * * \\
(0.017)\end{array}$ & $\begin{array}{l}0.042 * \\
(0.026)\end{array}$ & $\begin{array}{c}0.088 * * * \\
(0.024)\end{array}$ & $\begin{array}{c}0.089 * * * \\
(0.017)\end{array}$ & $\begin{array}{c}-0.086^{* * *} \\
(0.019)\end{array}$ & $\begin{array}{c}0.088 * * * \\
(0.017)\end{array}$ & $\begin{array}{c}0.070 * * * \\
(0.026)\end{array}$ & $\begin{array}{c}0.099 * * * \\
(0.024)\end{array}$ \\
\hline $\begin{array}{l}\text { Swedish } \\
\text { MNE }\end{array}$ & & & & & & & & $\begin{array}{c}0.151 * * * \\
(0.008) \\
\end{array}$ & $\begin{array}{c}0.139 * * * \\
(0.012) \\
\end{array}$ & $\begin{array}{c}0.184 * * * \\
(0.014) \\
\end{array}$ \\
\hline $\log (\mathrm{K} / \mathrm{L})$ & & & $\begin{array}{c}0.114 * * * \\
(0.001)\end{array}$ & $\begin{array}{c}0.111 \text { *** } \\
(0.003)\end{array}$ & $\begin{array}{c}0.124 * * * \\
(0.002)\end{array}$ & $\begin{array}{c}0.114 * * * \\
(0.001)\end{array}$ & $\begin{array}{c}0.108 * * * \\
(0.004)\end{array}$ & $\begin{array}{c}0.114 * * * \\
(0.001)\end{array}$ & $\begin{array}{c}0.111^{* * *} \\
(0.003)\end{array}$ & $\begin{array}{c}0.124 * * * \\
(0.002)\end{array}$ \\
\hline $\log (\mathrm{L})$ & & & $\begin{array}{c}0.017 * * * \\
(0.002)\end{array}$ & $\begin{array}{c}0.022 * * * \\
(0.004)\end{array}$ & $\begin{array}{c}0.012 * * * \\
(0.003)\end{array}$ & $\begin{array}{c}0.009 * * * \\
(0.002)\end{array}$ & $\begin{array}{c}0.000 \\
(0.004)\end{array}$ & $\begin{array}{c}0.008 * * * \\
(0.002)\end{array}$ & $\begin{array}{c}0.006 \\
(0.004)\end{array}$ & $\begin{array}{l}0.005^{*} \\
(0.003)\end{array}$ \\
\hline $\begin{array}{l}\text { Share skill } \\
\text { high }\end{array}$ & & & $\begin{array}{c}0.581 * * * \\
(0.009) \\
\end{array}$ & $\begin{array}{c}0.452 * * * \\
(0.027) \\
\end{array}$ & $\begin{array}{c}0.608 * * * \\
(0.010)\end{array}$ & $\begin{array}{c}0.565 * * * \\
(0.009) \\
\end{array}$ & $\begin{array}{c}0.702 * * * \\
(0.027) \\
\end{array}$ & $\begin{array}{c}0.573 * * * \\
(0.009) \\
\end{array}$ & $\begin{array}{c}0.438 * * * \\
(0.027) \\
\end{array}$ & $\begin{array}{c}0.600 * * * \\
(0.010)\end{array}$ \\
\hline Observations & 384,830 & 384,830 & 384,830 & 95,492 & 239,533 & 374,162 & 49,652 & 384,830 & 95,492 & 239,533 \\
\hline R-squared & 0.179 & 0.181 & 0.303 & 0.204 & 0.317 & 0.303 & 0.222 & 0.305 & 0.208 & 0.318 \\
\hline
\end{tabular}


Table 0A3.2: Productivity differences between foreign and Swedish firms, 1996-2009. Only firms with at least 100 employees.

\begin{tabular}{|c|c|c|c|c|c|c|c|c|c|c|}
\hline & All firms & All firms & All firms & Manu. & Service & Local firms & MNE & All firms & Manu. & Service \\
\hline & (1) & (2) & (3) & (4) & (5) & (6) & (7) & (8) & (9) & $(10)$ \\
\hline Foreign & $\begin{array}{c}0.063 * * * \\
(0.014) \\
\end{array}$ & & & & & & & & & \\
\hline Japan & & $\begin{array}{l}-0.017 \\
(0.073)\end{array}$ & $\begin{array}{c}0.033 \\
(0.073)\end{array}$ & $\begin{array}{c}0.120 \\
(0.075)\end{array}$ & $\begin{array}{l}-0.041 \\
(0.107)\end{array}$ & $\begin{array}{c}0.086 \\
(0.074)\end{array}$ & $\begin{array}{l}-0.041 \\
(0.073)\end{array}$ & $\begin{array}{c}0.083 \\
(0.074)\end{array}$ & $\begin{array}{c}0.216 * * * \\
(0.078)\end{array}$ & $\begin{array}{l}-0.014 \\
(0.107)\end{array}$ \\
\hline US & & $\begin{array}{c}0.147 * * * \\
(0.031)\end{array}$ & $\begin{array}{c}0.106 * * * \\
(0.025)\end{array}$ & $\begin{array}{c}0.112 * * * \\
(0.035)\end{array}$ & $\begin{array}{c}0.098 * * * \\
(0.036)\end{array}$ & $\begin{array}{c}0.158^{* * * *} \\
(0.026)\end{array}$ & $\begin{array}{c}0.024 \\
(0.027)\end{array}$ & $\begin{array}{c}0.157 * * * \\
(0.026)\end{array}$ & $\begin{array}{c}0.208 * * * \\
(0.037)\end{array}$ & $\begin{array}{c}0.128 * * * \\
(0.037)\end{array}$ \\
\hline Denmark & & $\begin{array}{c}0.007 \\
(0.037)\end{array}$ & $\begin{array}{c}0.008 \\
(0.028)\end{array}$ & $\begin{array}{c}0.028 \\
(0.036)\end{array}$ & $\begin{array}{l}-0.003 \\
(0.041)\end{array}$ & $\begin{array}{l}0.047 * \\
(0.028)\end{array}$ & $\begin{array}{c}-0.065^{* *} \\
(0.030)\end{array}$ & $\begin{array}{c}0.044 \\
(0.028)\end{array}$ & $\begin{array}{c}0.102 * * * \\
(0.037)\end{array}$ & $\begin{array}{c}0.016 \\
(0.041)\end{array}$ \\
\hline UK & & $\begin{array}{c}0.083 * * \\
(0.033)\end{array}$ & $\begin{array}{l}0.069 * * \\
(0.027)\end{array}$ & $\begin{array}{c}0.103 * * * \\
(0.039)\end{array}$ & $\begin{array}{c}0.048 \\
(0.039)\end{array}$ & $\begin{array}{c}0.115^{* * * *} \\
(0.028)\end{array}$ & $\begin{array}{l}-0.004 \\
(0.028)\end{array}$ & $\begin{array}{c}0.114 * * * \\
(0.028)\end{array}$ & $\begin{array}{c}0.200 * * * \\
(0.041)\end{array}$ & $\begin{array}{l}0.070^{*} \\
(0.040)\end{array}$ \\
\hline Germany & & $\begin{array}{l}0.073 * * \\
(0.035)\end{array}$ & $\begin{array}{c}0.024 \\
(0.029)\end{array}$ & $\begin{array}{c}0.035 \\
(0.047)\end{array}$ & $\begin{array}{c}0.003 \\
(0.038)\end{array}$ & $\begin{array}{c}0.066^{* *} \\
(0.030)\end{array}$ & $\begin{array}{l}-0.055^{*} \\
(0.031)\end{array}$ & $\begin{array}{c}0.066^{* *} \\
(0.029)\end{array}$ & $\begin{array}{c}0.131 * * * \\
(0.048)\end{array}$ & $\begin{array}{c}0.027 \\
(0.039)\end{array}$ \\
\hline France & & $\begin{array}{c}0.032 \\
(0.036)\end{array}$ & $\begin{array}{l}0.060 \text { ** } \\
(0.029)\end{array}$ & $\begin{array}{l}0.077 * \\
(0.044)\end{array}$ & $\begin{array}{l}0.065^{*} \\
(0.036)\end{array}$ & $\begin{array}{c}0.103 * * * \\
(0.030)\end{array}$ & $\begin{array}{l}-0.008 \\
(0.030)\end{array}$ & $\begin{array}{c}0.104 * * * \\
(0.029)\end{array}$ & $\begin{array}{c}0.171 * * * \\
(0.046)\end{array}$ & $\begin{array}{l}0.089 * * \\
(0.037)\end{array}$ \\
\hline Norway & & $\begin{array}{c}0.006 \\
(0.030)\end{array}$ & $\begin{array}{c}0.006 \\
(0.026)\end{array}$ & $\begin{array}{l}-0.022 \\
(0.038)\end{array}$ & $\begin{array}{c}0.007 \\
(0.038)\end{array}$ & $\begin{array}{c}0.051 * * \\
(0.026)\end{array}$ & $\begin{array}{c}-0.064 * * \\
(0.028)\end{array}$ & $\begin{array}{l}0.046^{*} \\
(0.026)\end{array}$ & $\begin{array}{c}0.059 \\
(0.039)\end{array}$ & $\begin{array}{c}0.027 \\
(0.038)\end{array}$ \\
\hline Netherlands & & $\begin{array}{c}0.125^{* * *} * \\
(0.035)\end{array}$ & $\begin{array}{c}0.096^{* * * *} \\
(0.029)\end{array}$ & $\begin{array}{c}0.034 \\
(0.033)\end{array}$ & $\begin{array}{c}0.170 * * * \\
(0.049)\end{array}$ & $\begin{array}{c}0.144 * * * \\
(0.030)\end{array}$ & $\begin{array}{c}0.012 \\
(0.030)\end{array}$ & $\begin{array}{c}0.143 * * * \\
(0.029)\end{array}$ & $\begin{array}{c}0.124 * * * \\
(0.035)\end{array}$ & $\begin{array}{c}0.195^{* * *} \\
(0.049)\end{array}$ \\
\hline Finland & & $\begin{array}{c}0.015 \\
(0.028)\end{array}$ & $\begin{array}{l}0.038^{*} \\
(0.023)\end{array}$ & $\begin{array}{c}0.041 \\
(0.030)\end{array}$ & $\begin{array}{l}-0.000 \\
(0.033)\end{array}$ & $\begin{array}{c}0.092 * * * \\
(0.024)\end{array}$ & $\begin{array}{l}-0.040^{*} \\
(0.024)\end{array}$ & $\begin{array}{c}0.087 * * * \\
(0.024)\end{array}$ & $\begin{array}{c}0.134 * * * \\
(0.032)\end{array}$ & $\begin{array}{c}0.026 \\
(0.033)\end{array}$ \\
\hline Switzerland & & $\begin{array}{c}0.106 * * * \\
(0.037)\end{array}$ & $\begin{array}{c}0.109 * * * * \\
(0.031)\end{array}$ & $\begin{array}{c}0.129 * * * \\
(0.044)\end{array}$ & $\begin{array}{c}0.068 \\
(0.048)\end{array}$ & $\begin{array}{c}0.162 * * * \\
(0.032)\end{array}$ & $\begin{array}{c}0.021 \\
(0.032)\end{array}$ & $\begin{array}{c}0.163 * * * * \\
(0.032)\end{array}$ & $\begin{array}{c}0.231 * * * \\
(0.046)\end{array}$ & $\begin{array}{l}0.095^{*} \\
(0.049)\end{array}$ \\
\hline $\begin{array}{l}\text { Foreign } \\
\text { other }\end{array}$ & & $\begin{array}{l}-0.016 \\
(0.038)\end{array}$ & $\begin{array}{l}-0.015 \\
(0.033) \\
\end{array}$ & $\begin{array}{c}0.020 \\
(0.036)\end{array}$ & $\begin{array}{l}-0.072 \\
(0.070) \\
\end{array}$ & $\begin{array}{c}0.036 \\
(0.034) \\
\end{array}$ & $\begin{array}{c}-0.083 * * \\
(0.034)\end{array}$ & $\begin{array}{c}0.033 \\
(0.034) \\
\end{array}$ & $\begin{array}{c}0.107 * * * \\
(0.037)\end{array}$ & $\begin{array}{l}-0.047 \\
(0.071) \\
\end{array}$ \\
\hline $\begin{array}{l}\text { Swedish } \\
\text { MNE }\end{array}$ & & & & & & & & $\begin{array}{c}0.131 * * * \\
(0.014) \\
\end{array}$ & $\begin{array}{c}0.179 * * * \\
(0.020) \\
\end{array}$ & $\begin{array}{c}0.107 * * * \\
(0.022) \\
\end{array}$ \\
\hline $\log (\mathrm{K} / \mathrm{L})$ & & & $\begin{array}{c}0.140 * * * \\
(0.006)\end{array}$ & $\begin{array}{c}0.164 * * * \\
(0.014)\end{array}$ & $\begin{array}{c}0.138 * * * \\
(0.007)\end{array}$ & $\begin{array}{c}0.143 * * * \\
(0.006)\end{array}$ & $\begin{array}{c}0.117 * * * \\
(0.007)\end{array}$ & $\begin{array}{c}0.140 * * * \\
(0.006)\end{array}$ & $\begin{array}{c}0.161 * * * \\
(0.013)\end{array}$ & $\begin{array}{c}0.138 * * * \\
(0.007)\end{array}$ \\
\hline $\log (\mathrm{L})$ & & & $\begin{array}{l}0.013^{*} \\
(0.008)\end{array}$ & $\begin{array}{c}0.013 \\
(0.015)\end{array}$ & $\begin{array}{c}0.005 \\
(0.009)\end{array}$ & $\begin{array}{l}-0.001 \\
(0.008)\end{array}$ & $\begin{array}{c}0.020^{* *} \\
(0.008)\end{array}$ & $\begin{array}{c}0.005 \\
(0.008)\end{array}$ & $\begin{array}{l}-0.002 \\
(0.015)\end{array}$ & $\begin{array}{c}0.000 \\
(0.009)\end{array}$ \\
\hline $\begin{array}{l}\text { Share skill } \\
\text { high }\end{array}$ & & & $\begin{array}{c}0.798 * * * \\
(0.040) \\
\end{array}$ & $\begin{array}{c}0.720 * * * \\
(0.100) \\
\end{array}$ & $\begin{array}{c}0.814 * * * \\
(0.045) \\
\end{array}$ & $\begin{array}{c}0.769 * * * \\
(0.043) \\
\end{array}$ & $\begin{array}{c}0.834 * * * \\
(0.048) \\
\end{array}$ & $\begin{array}{c}0.771 * * * \\
(0.040) \\
\end{array}$ & $\begin{array}{c}0.686 * * * \\
(0.096) \\
\end{array}$ & $\begin{array}{c}0.796 * * * \\
(0.045) \\
\end{array}$ \\
\hline Observations & 30,641 & 30,641 & 30,641 & 12,576 & 15,743 & 25,161 & 15,471 & 30,641 & 12,576 & 15,743 \\
\hline R-squared & 0.219 & 0.222 & 0.387 & 0.286 & 0.400 & 0.413 & 0.346 & 0.392 & 0.302 & 0.402 \\
\hline
\end{tabular}


Table 0A3.3: Productivity differences between foreign and Swedish firms, 1996-2009 (at least 10 employees). Only including 10 largest source countries.

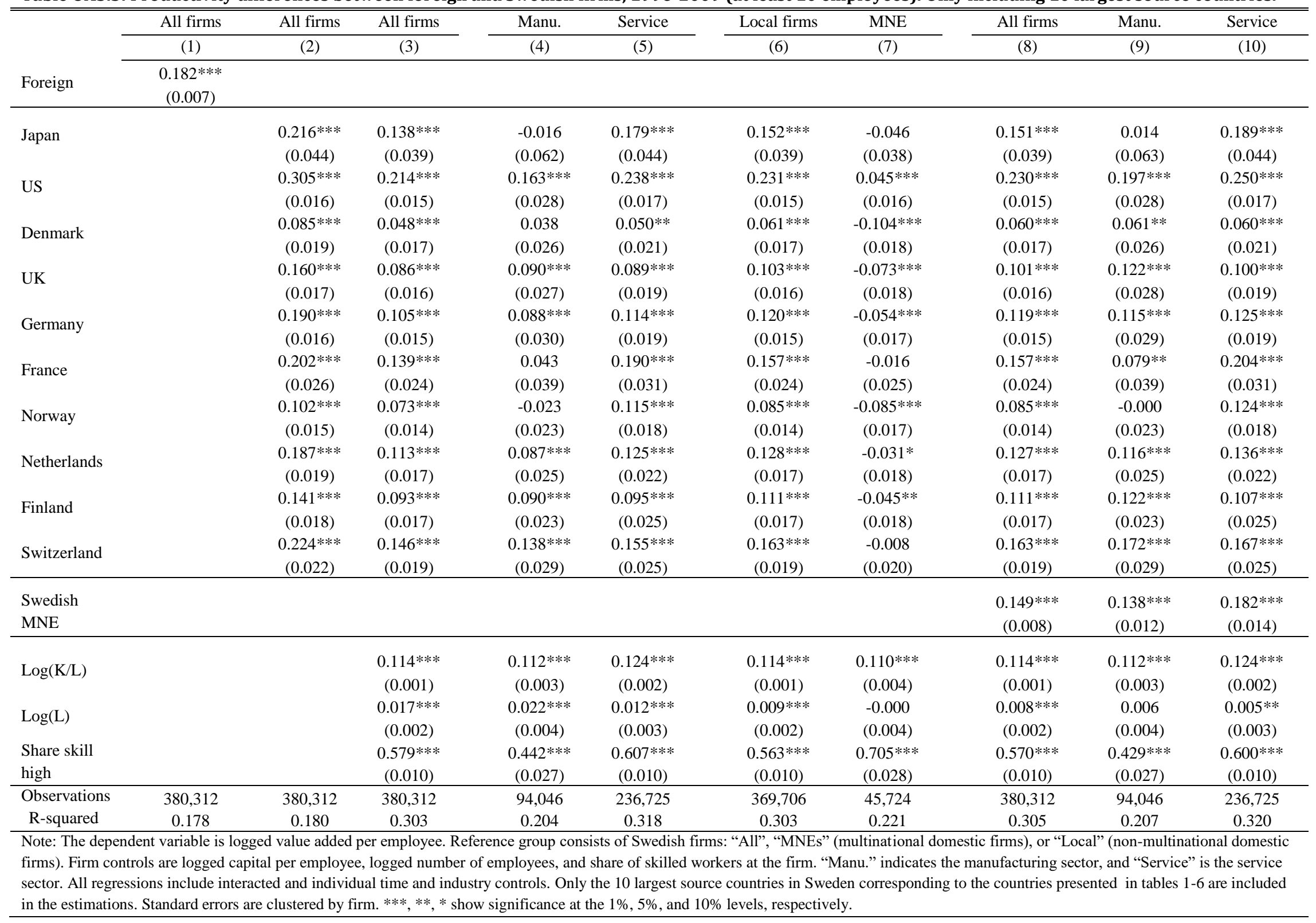


Table 5 with alternative restrictions and number of countries

Table 0A5.1: Productivity differences after acquisitions of Swedish firms by foreign firms 1996-2009 (at least 10 employees). No restrictions on switchers.

\begin{tabular}{|c|c|c|c|c|c|c|c|c|c|c|c|}
\hline \multirow[b]{3}{*}{ Foreign } & All firms & All firms & All firms & Manu. & Service & Local firms & MNE & Local Manu. & MNE Manu. & Local Serv. & MNE Serv. \\
\hline & (1) & (2) & (3) & (4) & (5) & (6) & $(7)$ & $(8)$ & (9) & (10) & $(11)$ \\
\hline & $\begin{array}{l}0.025 * * * \\
(0.009) \\
\end{array}$ & & & & & & & & & & \\
\hline \multirow[t]{2}{*}{ Japan } & & -0.036 & -0.048 & 0.060 & -0.073 & -0.026 & -0.179 & 0.252 & -0.157 & -0.070 & $-0.158 * *$ \\
\hline & & $(0.082)$ & $(0.088)$ & $(0.127)$ & $(0.110)$ & $(0.100)$ & $(0.119)$ & $(0.175)$ & $(0.159)$ & $(0.115)$ & $(0.064)$ \\
\hline \multirow{2}{*}{ US } & & 0.044 & $0.069 * *$ & $0.076^{*}$ & 0.059 & $0.082 * *$ & 0.036 & 0.089 & 0.094 & $0.077 *$ & -0.065 \\
\hline & & (0.028) & $(0.028)$ & $(0.040)$ & $(0.037)$ & $(0.033)$ & $(0.051)$ & $(0.055)$ & $(0.065)$ & $(0.041)$ & (0.086) \\
\hline \multirow{2}{*}{ Denmark } & & 0.021 & 0.024 & 0.041 & 0.015 & 0.017 & 0.051 & 0.039 & 0.046 & 0.006 & 0.113 \\
\hline & & $(0.019)$ & $(0.019)$ & $(0.029)$ & $(0.025)$ & $(0.020)$ & $(0.051)$ & (0.033) & $(0.060)$ & $(0.026)$ & $(0.088)$ \\
\hline \multirow{2}{*}{ UK } & & -0.008 & 0.006 & -0.043 & 0.013 & 0.006 & 0.002 & -0.076 & 0.013 & 0.023 & -0.098 \\
\hline & & $(0.024)$ & $(0.024)$ & $(0.042)$ & $(0.028)$ & $(0.025)$ & $(0.057)$ & $(0.060)$ & (0.049) & $(0.029)$ & $(0.084)$ \\
\hline \multirow{2}{*}{ Germany } & & 0.035 & $0.037 *$ & 0.053 & 0.030 & $0.040^{*}$ & 0.018 & 0.064 & 0.031 & 0.031 & -0.001 \\
\hline & & $(0.021)$ & $(0.021)$ & $(0.041)$ & $(0.028)$ & $(0.023)$ & $(0.052)$ & $(0.044)$ & $(0.076)$ & $(0.031)$ & $(0.055)$ \\
\hline \multirow{2}{*}{ France } & & 0.028 & 0.042 & -0.045 & $0.056^{*}$ & 0.040 & 0.056 & -0.123 & 0.067 & $0.060 *$ & 0.045 \\
\hline & & $(0.034)$ & $(0.035)$ & (0.094) & (0.034) & $(0.039)$ & $(0.076)$ & $(0.142)$ & $(0.081)$ & (0.036) & (0.098) \\
\hline \multirow{2}{*}{ Norway } & & 0.003 & 0.002 & $-0.094 * *$ & 0.016 & -0.006 & 0.014 & $-0.136^{* * *}$ & 0.034 & 0.018 & -0.033 \\
\hline & & $(0.020)$ & $(0.020)$ & $(0.043)$ & $(0.024)$ & $(0.021)$ & $(0.059)$ & $(0.050)$ & $(0.072)$ & $(0.024)$ & $(0.107)$ \\
\hline \multirow{2}{*}{ Netherlands } & & $0.051 * *$ & $0.047 * *$ & 0.033 & $0.052 *$ & 0.039 & $0.093 * *$ & 0.007 & 0.082 & 0.046 & $0.123 * *$ \\
\hline & & $(0.023)$ & $(0.022)$ & $(0.037)$ & $(0.028)$ & $(0.025)$ & $(0.041)$ & $(0.044)$ & $(0.060)$ & $(0.030)$ & $(0.050)$ \\
\hline \multirow{2}{*}{ Finland } & & 0.031 & $0.041^{*}$ & 0.003 & $0.082 * *$ & $0.048^{*}$ & 0.044 & 0.000 & 0.031 & $0.087^{* *}$ & 0.090 \\
\hline & & $(0.023)$ & $(0.023)$ & $(0.031)$ & $(0.034)$ & $(0.027)$ & $(0.039)$ & $(0.040)$ & $(0.043)$ & $(0.039)$ & $(0.078)$ \\
\hline \multirow{2}{*}{ Switzerland } & & 0.022 & 0.021 & 0.005 & 0.047 & 0.006 & 0.081 & -0.071 & 0.141 & 0.055 & -0.051 \\
\hline & & $(0.036)$ & $(0.035)$ & $(0.059)$ & $(0.043)$ & $(0.031)$ & $(0.115)$ & $(0.046)$ & $(0.123)$ & $(0.039)$ & $(0.248)$ \\
\hline \multirow{2}{*}{ Foreign Other } & & 0.009 & 0.010 & 0.016 & 0.023 & 0.008 & 0.041 & -0.003 & 0.092 & 0.029 & -0.033 \\
\hline & & $(0.025)$ & $(0.025)$ & $(0.033)$ & $(0.038)$ & $(0.027)$ & $(0.059)$ & $(0.036)$ & $(0.067)$ & $(0.040)$ & $(0.113)$ \\
\hline \multirow{2}{*}{$\log (\mathrm{K} / \mathrm{L})$} & & & $0.073 * * *$ & $0.087 * * *$ & $0.068 * * *$ & $0.074 * * *$ & $0.065^{* * *}$ & $0.080^{* *}$ & $0.105^{* * *}$ & $0.070 * * *$ & $0.030 *$ \\
\hline & & & $(0.007)$ & $(0.024)$ & $(0.006)$ & $(0.008)$ & $(0.019)$ & $(0.032)$ & $(0.037)$ & $(0.007)$ & $(0.017)$ \\
\hline \multirow{2}{*}{$\log (\mathrm{L})$} & & & $-0.109 * * *$ & $-0.100 * * *$ & $-0.132 * * *$ & $-0.102 * * *$ & $-0.128 * * *$ & $-0.072 * * *$ & $-0.121 * * *$ & $-0.136 * * *$ & $-0.116^{* * *}$ \\
\hline & & & $(0.012)$ & $(0.021)$ & $(0.015)$ & $(0.013)$ & $(0.027)$ & $(0.027)$ & $(0.039)$ & $(0.016)$ & $(0.039)$ \\
\hline \multirow{2}{*}{ Share skill high } & & & 0.049 & -0.064 & 0.056 & 0.041 & 0.067 & -0.008 & -0.352 & 0.044 & 0.289 \\
\hline & & & $(0.055)$ & $(0.110)$ & $(0.064)$ & $(0.059)$ & $(0.199)$ & $(0.126)$ & $(0.269)$ & $(0.066)$ & $(0.276)$ \\
\hline Observations & 40,858 & 40,858 & 40,858 & 12,465 & 26,431 & 32,775 & 6,194 & 8,163 & 3,735 & 22,803 & 2,387 \\
\hline R-squared & 0.033 & 0.034 & 0.059 & 0.056 & 0.060 & 0.057 & 0.072 & 0.048 & 0.076 & 0.061 & 0.075 \\
\hline
\end{tabular}


Table 0A5.2: Productivity differences after acquisitions of Swedish firms by foreign firms 1996-2009 (at least 10 employees).0nly firms with at least 100 employees.

\begin{tabular}{|c|c|c|c|c|c|c|c|c|c|c|c|}
\hline & $\begin{array}{c}\text { All firms } \\
(1)\end{array}$ & $\frac{\text { All firms }}{(2)}$ & $\begin{array}{c}\text { All firms } \\
(3)\end{array}$ & $\begin{array}{c}\text { Manu. } \\
(4)\end{array}$ & $\begin{array}{c}\text { Service } \\
(5)\end{array}$ & $\begin{array}{c}\text { Local firms } \\
(6)\end{array}$ & $\begin{array}{c}\text { MNE } \\
(7)\end{array}$ & $\begin{array}{c}\text { Local Manu. } \\
(8)\end{array}$ & $\frac{\text { MNE Manu. }}{(9)}$ & $\frac{\text { Local Serv. }}{(10)}$ & $\frac{\text { MNE Serv. }}{(11)}$ \\
\hline Foreign & $\begin{array}{c}0.021 \\
(0.017)\end{array}$ & & & & & & & & & & \\
\hline Japan & & $\begin{array}{l}-0.142^{*} \\
(0.078)\end{array}$ & $\begin{array}{l}-0.157^{*} \\
(0.082)\end{array}$ & $\begin{array}{l}-0.103 \\
(0.115)\end{array}$ & $\begin{array}{c}-0.220^{* *} \\
(0.111)\end{array}$ & $\begin{array}{l}-0.150 \\
(0.114)\end{array}$ & $\begin{array}{l}-0.143 \\
(0.121)\end{array}$ & $\begin{array}{c}0.037 \\
(0.040)\end{array}$ & $\begin{array}{l}-0.157 \\
(0.157)\end{array}$ & $\begin{array}{l}-0.230 \\
(0.154)\end{array}$ & $\begin{array}{l}-0.108 \\
(0.133)\end{array}$ \\
\hline US & & $\begin{array}{l}-0.047 \\
(0.047)\end{array}$ & $\begin{array}{l}-0.030 \\
(0.047)\end{array}$ & $\begin{array}{l}-0.003 \\
(0.048)\end{array}$ & $\begin{array}{c}0.005 \\
(0.084)\end{array}$ & $\begin{array}{l}-0.051 \\
(0.081)\end{array}$ & $\begin{array}{c}0.012 \\
(0.052)\end{array}$ & $\begin{array}{c}0.001 \\
(0.081)\end{array}$ & $\begin{array}{c}0.025 \\
(0.061)\end{array}$ & $\begin{array}{l}-0.004 \\
(0.121)\end{array}$ & $\begin{array}{c}0.048 \\
(0.103)\end{array}$ \\
\hline Denmark & & $\begin{array}{c}0.029 \\
(0.034)\end{array}$ & $\begin{array}{c}0.018 \\
(0.033)\end{array}$ & $\begin{array}{l}-0.034 \\
(0.051)\end{array}$ & $\begin{array}{c}0.044 \\
(0.042)\end{array}$ & $\begin{array}{c}0.008 \\
(0.041)\end{array}$ & $\begin{array}{c}0.018 \\
(0.059)\end{array}$ & $\begin{array}{l}-0.090 \\
(0.085)\end{array}$ & $\begin{array}{l}-0.007 \\
(0.062)\end{array}$ & $\begin{array}{c}0.025 \\
(0.045)\end{array}$ & $\begin{array}{c}0.230^{* * *} \\
(0.099)\end{array}$ \\
\hline UK & & $\begin{array}{c}0.000 \\
(0.049)\end{array}$ & $\begin{array}{c}0.006 \\
(0.047)\end{array}$ & $\begin{array}{l}-0.054 \\
(0.055)\end{array}$ & $\begin{array}{c}0.024 \\
(0.069)\end{array}$ & $\begin{array}{c}0.059 \\
(0.068)\end{array}$ & $\begin{array}{l}-0.047 \\
(0.055)\end{array}$ & $\begin{array}{l}-0.114 \\
(0.103)\end{array}$ & $\begin{array}{l}-0.007 \\
(0.059)\end{array}$ & $\begin{array}{c}0.108 \\
(0.081)\end{array}$ & $\begin{array}{l}-0.153 \\
(0.098)\end{array}$ \\
\hline Germany & & $\begin{array}{c}0.049 \\
(0.031)\end{array}$ & $\begin{array}{l}0.052 * \\
(0.030)\end{array}$ & $\begin{array}{c}0.128 * * * \\
(0.044)\end{array}$ & $\begin{array}{l}-0.075^{*} \\
(0.045)\end{array}$ & $\begin{array}{c}0.023 \\
(0.032)\end{array}$ & $\begin{array}{c}0.059 \\
(0.056)\end{array}$ & $\begin{array}{c}0.027 \\
(0.066)\end{array}$ & $\begin{array}{c}0.139 * * * \\
(0.051)\end{array}$ & $\begin{array}{c}-0.078^{* *} \\
(0.035)\end{array}$ & $\begin{array}{l}-0.077 \\
(0.125)\end{array}$ \\
\hline France & & $\begin{array}{c}0.045 \\
(0.048)\end{array}$ & $\begin{array}{c}0.050 \\
(0.049)\end{array}$ & $\begin{array}{c}0.099 \\
(0.081)\end{array}$ & $\begin{array}{c}0.014 \\
(0.054)\end{array}$ & $\begin{array}{c}0.030 \\
(0.062)\end{array}$ & $\begin{array}{c}0.065 \\
(0.074)\end{array}$ & $\begin{array}{c}0.030 \\
(0.166)\end{array}$ & $\begin{array}{c}0.072 \\
(0.089)\end{array}$ & $\begin{array}{c}0.006 \\
(0.071)\end{array}$ & $\begin{array}{c}0.076 \\
(0.083)\end{array}$ \\
\hline Norway & & $\begin{array}{l}-0.053 \\
(0.058)\end{array}$ & $\begin{array}{l}-0.054 \\
(0.057)\end{array}$ & $\begin{array}{l}-0.055 \\
(0.118)\end{array}$ & $\begin{array}{l}-0.062 \\
(0.074)\end{array}$ & $\begin{array}{c}-0.135 * * \\
(0.065)\end{array}$ & $\begin{array}{c}0.072 \\
(0.088)\end{array}$ & $\begin{array}{l}-0.301 \\
(0.186)\end{array}$ & $\begin{array}{l}0.149 * \\
(0.076)\end{array}$ & $\begin{array}{l}-0.066 \\
(0.051)\end{array}$ & $\begin{array}{l}-0.020 \\
(0.186)\end{array}$ \\
\hline Netherlands & & $\begin{array}{c}0.083 * * \\
(0.034)\end{array}$ & $\begin{array}{c}0.076 \text { ** } \\
(0.036)\end{array}$ & $\begin{array}{l}0.112 * * \\
(0.043)\end{array}$ & $\begin{array}{c}0.049 \\
(0.067)\end{array}$ & $\begin{array}{l}0.080^{*} \\
(0.047)\end{array}$ & $\begin{array}{c}0.098 * * \\
(0.049)\end{array}$ & $\begin{array}{c}0.143 * * \\
(0.069)\end{array}$ & $\begin{array}{l}0.099 * \\
(0.056)\end{array}$ & $\begin{array}{c}0.038 \\
(0.067)\end{array}$ & $\begin{array}{c}0.135 \\
(0.114)\end{array}$ \\
\hline Finland & & $\begin{array}{c}0.045 \\
(0.030)\end{array}$ & $\begin{array}{l}0.054^{*} \\
(0.029)\end{array}$ & $\begin{array}{c}0.072 \\
(0.050)\end{array}$ & $\begin{array}{c}0.031 \\
(0.034)\end{array}$ & $\begin{array}{c}0.089 * * \\
(0.039)\end{array}$ & $\begin{array}{c}0.030 \\
(0.040)\end{array}$ & $\begin{array}{c}0.189 * * \\
(0.095)\end{array}$ & $\begin{array}{c}0.025 \\
(0.055)\end{array}$ & $\begin{array}{c}0.014 \\
(0.031)\end{array}$ & $\begin{array}{c}0.061 \\
(0.061)\end{array}$ \\
\hline Switzerland & & $\begin{array}{c}0.072 \\
(0.109)\end{array}$ & $\begin{array}{c}0.066 \\
(0.102)\end{array}$ & $\begin{array}{c}0.136 \\
(0.123)\end{array}$ & $\begin{array}{l}-0.052 \\
(0.169)\end{array}$ & $\begin{array}{c}0.058 \\
(0.077)\end{array}$ & $\begin{array}{c}0.076 \\
(0.162)\end{array}$ & $\begin{array}{c}0.019 \\
(0.041)\end{array}$ & $\begin{array}{c}0.163 \\
(0.159)\end{array}$ & $\begin{array}{c}0.113 \\
(0.129)\end{array}$ & $\begin{array}{c}-0.556^{* * * *} \\
(0.044)\end{array}$ \\
\hline Foreign Other & & $\begin{array}{c}-0.125^{* *} \\
(0.049)\end{array}$ & $\begin{array}{c}-0.126^{* * * *} \\
(0.049)\end{array}$ & $\begin{array}{l}-0.078 \\
(0.052)\end{array}$ & $\begin{array}{l}-0.238^{*} \\
(0.132)\end{array}$ & $\begin{array}{l}-0.096^{*} \\
(0.057)\end{array}$ & $\begin{array}{l}-0.151^{*} \\
(0.078)\end{array}$ & $\begin{array}{l}-0.078 \\
(0.088)\end{array}$ & $\begin{array}{l}-0.081 \\
(0.055)\end{array}$ & $\begin{array}{l}-0.154^{*} \\
(0.091)\end{array}$ & $\begin{array}{l}-0.335 \\
(0.265)\end{array}$ \\
\hline $\log (\mathrm{K} / \mathrm{L})$ & & & $\begin{array}{c}0.062 * * * \\
(0.017)\end{array}$ & $\begin{array}{c}0.054 * * \\
(0.022)\end{array}$ & $\begin{array}{c}0.066 * * * \\
(0.022)\end{array}$ & $\begin{array}{c}0.064 * * * \\
(0.021)\end{array}$ & $\begin{array}{l}0.067 * \\
(0.035)\end{array}$ & $\begin{array}{c}0.005 \\
(0.030)\end{array}$ & $\begin{array}{l}0.075^{*} \\
(0.043)\end{array}$ & $\begin{array}{c}0.086 * * * \\
(0.028)\end{array}$ & $\begin{array}{c}0.030 \\
(0.031)\end{array}$ \\
\hline $\log (\mathrm{L})$ & & & $\begin{array}{c}-0.108^{* * * *} \\
(0.023)\end{array}$ & $\begin{array}{l}-0.050 \\
(0.048)\end{array}$ & $\begin{array}{c}-0.160 * * * \\
(0.028)\end{array}$ & $\begin{array}{c}-0.122 * * * \\
(0.029)\end{array}$ & $\begin{array}{c}-0.076^{* *} \\
(0.038)\end{array}$ & $\begin{array}{l}-0.099 \\
(0.084)\end{array}$ & $\begin{array}{c}0.016 \\
(0.061)\end{array}$ & $\begin{array}{c}-0.153 * * * \\
(0.031)\end{array}$ & $\begin{array}{c}-0.136^{* *} \\
(0.052)\end{array}$ \\
\hline Share skill high & & & $\begin{array}{c}0.281 \\
(0.221) \\
\end{array}$ & $\begin{array}{l}-0.200 \\
(0.371)\end{array}$ & $\begin{array}{c}0.443 \\
(0.298) \\
\end{array}$ & $\begin{array}{c}0.505 \\
(0.311) \\
\end{array}$ & $\begin{array}{l}-0.098 \\
(0.354)\end{array}$ & $\begin{array}{c}0.120 \\
(0.720)\end{array}$ & $\begin{array}{l}-0.697 \\
(0.440)\end{array}$ & $\begin{array}{c}0.646 * * \\
(0.266) \\
\end{array}$ & $\begin{array}{c}0.163 \\
(0.643)\end{array}$ \\
\hline Observations & 8,166 & 8,166 & 8,166 & 3,959 & 3,689 & 4,221 & 3,517 & 1,375 & 2,404 & 2,385 & 1,054 \\
\hline R-squared & 0.035 & 0.039 & 0.060 & 0.051 & 0.087 & 0.074 & 0.062 & 0.065 & 0.073 & 0.113 & 0.098 \\
\hline
\end{tabular}


Table 0A5.3: Productivity differences after acquisitions of Swedish firms by foreign firms 1996-2009 (at least 10 employees). Only including 10 largest source countries.

\begin{tabular}{|c|c|c|c|c|c|c|c|c|c|c|c|}
\hline & $\begin{array}{c}\text { All firms } \\
(1)\end{array}$ & $\begin{array}{c}\text { All firms } \\
(2)\end{array}$ & $\begin{array}{c}\text { All firms } \\
(3)\end{array}$ & $\begin{array}{c}\text { Manu. } \\
(4)\end{array}$ & $\begin{array}{c}\text { Service } \\
(5)\end{array}$ & $\begin{array}{c}\text { Local firms } \\
(6)\end{array}$ & $\begin{array}{c}\text { MNE } \\
(7)\end{array}$ & $\begin{array}{c}\text { Local Manu. } \\
(8)\end{array}$ & $\begin{array}{c}\text { MNE Manu. } \\
(9)\end{array}$ & $\begin{array}{c}\text { Local Serv. } \\
(10)\end{array}$ & $\frac{\text { MNE Serv. }}{(11)}$ \\
\hline Foreign & $\begin{array}{c}0.027 * * * \\
(0.010) \\
\end{array}$ & & & & & & & & & & \\
\hline Japan & & $\begin{array}{l}-0.038 \\
(0.083)\end{array}$ & $\begin{array}{l}-0.051 \\
(0.089)\end{array}$ & $\begin{array}{c}0.051 \\
(0.129)\end{array}$ & $\begin{array}{l}-0.071 \\
(0.109)\end{array}$ & $\begin{array}{l}-0.029 \\
(0.101)\end{array}$ & $\begin{array}{l}-0.177 \\
(0.120)\end{array}$ & $\begin{array}{c}0.243 \\
(0.181)\end{array}$ & $\begin{array}{l}-0.157 \\
(0.161)\end{array}$ & $\begin{array}{l}-0.069 \\
(0.115)\end{array}$ & $\begin{array}{c}-0.150 * * \\
(0.069)\end{array}$ \\
\hline US & & $\begin{array}{l}0.049 * \\
(0.029)\end{array}$ & $\begin{array}{c}0.074 * * \\
(0.029)\end{array}$ & $\begin{array}{l}0.075^{*} \\
(0.040)\end{array}$ & $\begin{array}{l}0.064 * \\
(0.038)\end{array}$ & $\begin{array}{c}0.086^{* * *} \\
(0.034)\end{array}$ & $\begin{array}{c}0.049 \\
(0.053)\end{array}$ & $\begin{array}{c}0.090 \\
(0.056)\end{array}$ & $\begin{array}{c}0.101 \\
(0.065)\end{array}$ & $\begin{array}{l}0.080^{*} \\
(0.041)\end{array}$ & $\begin{array}{l}-0.050 \\
(0.093)\end{array}$ \\
\hline Denmark & & $\begin{array}{c}0.024 \\
(0.019)\end{array}$ & $\begin{array}{c}0.026 \\
(0.019)\end{array}$ & $\begin{array}{c}0.043 \\
(0.029)\end{array}$ & $\begin{array}{c}0.018 \\
(0.026)\end{array}$ & $\begin{array}{c}0.019 \\
(0.020)\end{array}$ & $\begin{array}{c}0.053 \\
(0.051)\end{array}$ & $\begin{array}{c}0.042 \\
(0.034)\end{array}$ & $\begin{array}{c}0.046 \\
(0.060)\end{array}$ & $\begin{array}{c}0.009 \\
(0.026)\end{array}$ & $\begin{array}{c}0.121 \\
(0.088)\end{array}$ \\
\hline UK & & $\begin{array}{l}-0.012 \\
(0.024)\end{array}$ & $\begin{array}{c}0.003 \\
(0.024)\end{array}$ & $\begin{array}{l}-0.049 \\
(0.044)\end{array}$ & $\begin{array}{c}0.012 \\
(0.028)\end{array}$ & $\begin{array}{c}0.003 \\
(0.026)\end{array}$ & $\begin{array}{l}-0.003 \\
(0.062)\end{array}$ & $\begin{array}{l}-0.086 \\
(0.063)\end{array}$ & $\begin{array}{c}0.010 \\
(0.054)\end{array}$ & $\begin{array}{c}0.022 \\
(0.029)\end{array}$ & $\begin{array}{l}-0.114 \\
(0.089)\end{array}$ \\
\hline Germany & & $\begin{array}{c}0.030 \\
(0.022)\end{array}$ & $\begin{array}{c}0.030 \\
(0.022)\end{array}$ & $\begin{array}{c}0.042 \\
(0.042)\end{array}$ & $\begin{array}{c}0.025 \\
(0.028)\end{array}$ & $\begin{array}{c}0.036 \\
(0.024)\end{array}$ & $\begin{array}{l}-0.004 \\
(0.056)\end{array}$ & $\begin{array}{c}0.054 \\
(0.045)\end{array}$ & $\begin{array}{c}0.012 \\
(0.084)\end{array}$ & $\begin{array}{c}0.028 \\
(0.031)\end{array}$ & $\begin{array}{l}-0.012 \\
(0.054)\end{array}$ \\
\hline France & & $\begin{array}{c}0.031 \\
(0.035)\end{array}$ & $\begin{array}{c}0.045 \\
(0.035)\end{array}$ & $\begin{array}{l}-0.041 \\
(0.095)\end{array}$ & $\begin{array}{l}0.059^{*} \\
(0.034)\end{array}$ & $\begin{array}{c}0.044 \\
(0.039)\end{array}$ & $\begin{array}{c}0.059 \\
(0.076)\end{array}$ & $\begin{array}{l}-0.116 \\
(0.144)\end{array}$ & $\begin{array}{c}0.072 \\
(0.079)\end{array}$ & $\begin{array}{l}0.062 * \\
(0.036)\end{array}$ & $\begin{array}{c}0.049 \\
(0.099)\end{array}$ \\
\hline Norway & & $\begin{array}{c}0.003 \\
(0.021)\end{array}$ & $\begin{array}{c}0.002 \\
(0.021)\end{array}$ & $\begin{array}{c}-0.099 * * \\
(0.043)\end{array}$ & $\begin{array}{c}0.019 \\
(0.025)\end{array}$ & $\begin{array}{l}-0.006 \\
(0.022)\end{array}$ & $\begin{array}{c}0.016 \\
(0.062)\end{array}$ & $\begin{array}{c}-0.141 * * * \\
(0.050)\end{array}$ & $\begin{array}{c}0.019 \\
(0.072)\end{array}$ & $\begin{array}{c}0.020 \\
(0.025)\end{array}$ & $\begin{array}{l}-0.015 \\
(0.119)\end{array}$ \\
\hline Netherlands & & $\begin{array}{c}0.049 * * \\
(0.023)\end{array}$ & $\begin{array}{c}0.045^{* * *} \\
(0.022)\end{array}$ & $\begin{array}{c}0.032 \\
(0.037)\end{array}$ & $\begin{array}{l}0.054 * \\
(0.028)\end{array}$ & $\begin{array}{c}0.036 \\
(0.025)\end{array}$ & $\begin{array}{c}0.089 * * \\
(0.041)\end{array}$ & $\begin{array}{c}0.006 \\
(0.044)\end{array}$ & $\begin{array}{c}0.084 \\
(0.062)\end{array}$ & $\begin{array}{c}0.047 \\
(0.030)\end{array}$ & $\begin{array}{c}0.130^{* * *} \\
(0.051)\end{array}$ \\
\hline Finland & & $\begin{array}{c}0.026 \\
(0.023)\end{array}$ & $\begin{array}{c}0.036 \\
(0.023)\end{array}$ & $\begin{array}{c}0.002 \\
(0.032)\end{array}$ & $\begin{array}{c}0.075^{* * *} \\
(0.034)\end{array}$ & $\begin{array}{c}0.044 \\
(0.027)\end{array}$ & $\begin{array}{c}0.044 \\
(0.040)\end{array}$ & $\begin{array}{l}-0.001 \\
(0.042)\end{array}$ & $\begin{array}{c}0.032 \\
(0.043)\end{array}$ & $\begin{array}{c}0.080^{* * *} \\
(0.039)\end{array}$ & $\begin{array}{c}0.094 \\
(0.082)\end{array}$ \\
\hline Switzerland & & $\begin{array}{c}0.014 \\
(0.037)\end{array}$ & $\begin{array}{c}0.011 \\
(0.036)\end{array}$ & $\begin{array}{l}-0.019 \\
(0.064)\end{array}$ & $\begin{array}{c}0.048 \\
(0.043)\end{array}$ & $\begin{array}{l}-0.006 \\
(0.033)\end{array}$ & $\begin{array}{c}0.083 \\
(0.121)\end{array}$ & $\begin{array}{c}-0.116^{* *} \\
(0.049)\end{array}$ & $\begin{array}{c}0.140 \\
(0.130)\end{array}$ & $\begin{array}{c}0.057 \\
(0.039)\end{array}$ & $\begin{array}{l}-0.046 \\
(0.247)\end{array}$ \\
\hline $\log (\mathrm{K} / \mathrm{L})$ & & & $\begin{array}{c}0.074 * * * \\
(0.008)\end{array}$ & $\begin{array}{c}0.091 * * * \\
(0.025)\end{array}$ & $\begin{array}{c}0.067 * * * \\
(0.006)\end{array}$ & $\begin{array}{c}0.075 * * * \\
(0.008)\end{array}$ & $\begin{array}{c}0.071 * * * \\
(0.020)\end{array}$ & $\begin{array}{c}0.084 * * \\
(0.034)\end{array}$ & $\begin{array}{c}0.123 * * * \\
(0.038)\end{array}$ & $\begin{array}{c}0.069 * * * \\
(0.007)\end{array}$ & $\begin{array}{l}0.031^{*} \\
(0.017)\end{array}$ \\
\hline $\log (\mathrm{L})$ & & & $\begin{array}{c}-0.107 * * * \\
(0.012)\end{array}$ & $\begin{array}{c}-0.105^{* * * *} \\
(0.021)\end{array}$ & $\begin{array}{c}-0.123^{* * * *} \\
(0.015)\end{array}$ & $\begin{array}{c}-0.098 * * * \\
(0.014)\end{array}$ & $\begin{array}{c}-0.131 * * * \\
(0.028)\end{array}$ & $\begin{array}{c}-0.075^{* * * *} \\
(0.028)\end{array}$ & $\begin{array}{c}-0.141 * * * \\
(0.036)\end{array}$ & $\begin{array}{c}-0.128 * * * \\
(0.017)\end{array}$ & $\begin{array}{c}-0.105^{* * *} * \\
(0.040)\end{array}$ \\
\hline Share skill high & & & $\begin{array}{c}0.055 \\
(0.057) \\
\end{array}$ & $\begin{array}{l}-0.028 \\
(0.113) \\
\end{array}$ & $\begin{array}{c}0.049 \\
(0.066) \\
\end{array}$ & $\begin{array}{c}0.038 \\
(0.060) \\
\end{array}$ & $\begin{array}{c}0.082 \\
(0.207) \\
\end{array}$ & $\begin{array}{c}0.028 \\
(0.129) \\
\end{array}$ & $\begin{array}{l}-0.382 \\
(0.259) \\
\end{array}$ & $\begin{array}{c}0.031 \\
(0.069) \\
\end{array}$ & $\begin{array}{c}0.296 \\
(0.296) \\
\end{array}$ \\
\hline Observations & 38,581 & 38,581 & 38,581 & 11,675 & 25,052 & 30,859 & 5,831 & 7,564 & 3,511 & 21,589 & 2,248 \\
\hline R-squared & 0.033 & 0.033 & 0.059 & 0.058 & 0.058 & 0.057 & 0.072 & 0.051 & 0.082 & 0.059 & 0.071 \\
\hline
\end{tabular}




\section{Table 6 with different weights}

Table 0A6.1: WMS management index calculated in different ways. Regressions weighted by the number of observations per country in the WMS data, 2000-2009.

\begin{tabular}{|c|c|c|c|c|c|c|}
\hline Variables & Management 1 & Management 2 & Management 3 & Management 4 & Management 5 & Management 6 \\
\hline Denmark & $\begin{array}{c}0.287 \\
(0.862)\end{array}$ & $\begin{array}{c}0.290 \\
(0.909)\end{array}$ & $\begin{array}{c}0.291 \\
(0.821)\end{array}$ & $\begin{array}{c}0.280 \\
(0.781)\end{array}$ & $\begin{array}{l}-0.015 \\
(0.337)\end{array}$ & $\begin{array}{l}-0.001 \\
(0.341)\end{array}$ \\
\hline Finland & $\begin{array}{c}0.200 \\
(0.603)\end{array}$ & $\begin{array}{c}0.290 \\
(0.636)\end{array}$ & $\begin{array}{c}0.291 \\
(0.574)\end{array}$ & $\begin{array}{c}0.141 \\
(0.546)\end{array}$ & $\begin{array}{c}0.046 \\
(0.236)\end{array}$ & $\begin{array}{l}-0.001 \\
(0.239)\end{array}$ \\
\hline France & $\begin{array}{c}0.487 * * * \\
(0.163)\end{array}$ & $\begin{array}{c}0.478 * * * \\
(0.173)\end{array}$ & $\begin{array}{c}0.374 * * * \\
(0.113)\end{array}$ & $\begin{array}{c}0.369 * * * \\
(0.107)\end{array}$ & $\begin{array}{c}0.169 * * \\
(0.071)\end{array}$ & $\begin{array}{c}0.187 * * * \\
(0.069)\end{array}$ \\
\hline Japan & $\begin{array}{c}0.356 * * \\
(0.174)\end{array}$ & $\begin{array}{c}0.420 * * \\
(0.184)\end{array}$ & $\begin{array}{c}0.453 * * * \\
(0.146)\end{array}$ & $\begin{array}{c}0.332 * * \\
(0.139)\end{array}$ & $\begin{array}{c}0.190 * * \\
(0.077)\end{array}$ & $\begin{array}{l}0.128^{*} \\
(0.073)\end{array}$ \\
\hline Netherlands & $\begin{array}{c}0.461 \\
(0.339)\end{array}$ & $\begin{array}{c}0.374 \\
(0.371)\end{array}$ & $\begin{array}{c}0.374 \\
(0.335)\end{array}$ & $\begin{array}{c}0.443 \\
(0.307)\end{array}$ & $\begin{array}{c}0.167 \\
(0.135)\end{array}$ & $\begin{array}{c}0.082 \\
(0.141)\end{array}$ \\
\hline Norway & $\begin{array}{c}0.140 \\
(0.867)\end{array}$ & $\begin{array}{c}0.191 \\
(0.931)\end{array}$ & $\begin{array}{c}0.192 \\
(0.841)\end{array}$ & $\begin{array}{c}0.091 \\
(0.785)\end{array}$ & $\begin{array}{l}-0.117 \\
(0.347)\end{array}$ & $\begin{array}{l}-0.100 \\
(0.350)\end{array}$ \\
\hline Switzerland & $\begin{array}{c}0.418 \\
(0.302)\end{array}$ & $\begin{array}{c}0.438 \\
(0.321)\end{array}$ & $\begin{array}{c}0.438 \\
(0.290)\end{array}$ & $\begin{array}{c}0.413 \\
(0.273)\end{array}$ & $\begin{array}{c}0.170 \\
(0.123)\end{array}$ & $\begin{array}{c}0.147 \\
(0.123)\end{array}$ \\
\hline UK & $\begin{array}{c}0.401 * * * \\
(0.129)\end{array}$ & $\begin{array}{c}0.452 * * * \\
(0.136)\end{array}$ & $\begin{array}{c}0.177 * * * \\
(0.062)\end{array}$ & $\begin{array}{l}0.126^{*} \\
(0.065)\end{array}$ & $\begin{array}{c}0.211 * * * \\
(0.059)\end{array}$ & $\begin{array}{c}0.160 * * * \\
(0.056)\end{array}$ \\
\hline Germany & $\begin{array}{c}0.366 * * * \\
(0.100)\end{array}$ & $\begin{array}{c}0.390 * * * \\
(0.106)\end{array}$ & $\begin{array}{c}0.393 * * * \\
(0.075)\end{array}$ & $\begin{array}{c}0.281 * * * \\
(0.071)\end{array}$ & $\begin{array}{c}0.071 \\
(0.049)\end{array}$ & $\begin{array}{c}0.098 * * \\
(0.046)\end{array}$ \\
\hline US & $\begin{array}{c}0.505 * * * \\
(0.048)\end{array}$ & $\begin{array}{c}0.505 * * * \\
(0.048)\end{array}$ & $\begin{array}{c}0.552 * * * \\
(0.036)\end{array}$ & $\begin{array}{c}0.407 * * * \\
(0.036)\end{array}$ & $\begin{array}{c}0.288 * * * \\
(0.034)\end{array}$ & $\begin{array}{c}0.213 * * * \\
(0.030)\end{array}$ \\
\hline Constant & $\begin{array}{r}3.071 * * \\
(1.427) \\
\end{array}$ & $\begin{array}{c}2.839 * * * \\
(0.008) \\
\end{array}$ & $\begin{array}{c}2.839 * * * \\
(0.008) \\
\end{array}$ & 2.917 & $\begin{array}{c}2.845 \\
(2.153) \\
\end{array}$ & $\begin{array}{c}3.130 * * * \\
(0.024) \\
\end{array}$ \\
\hline Sample in WMS & $\begin{array}{l}\text { Domestic firms } \\
\text { and foreign } \\
\text { MNEs }\end{array}$ & $\begin{array}{l}\text { Domestic firms } \\
\text { and foreign } \\
\text { MNEs }\end{array}$ & All firms & All firms & Foreign MNEs & Foreign MNEs \\
\hline $\begin{array}{l}\text { Pairwise } \\
\text { country and } \\
\text { year FE }\end{array}$ & Yes & No & No & Yes & Yes & No \\
\hline Industry FE & Yes & No & No & Yes & Yes & No \\
\hline Observations & 6,367 & 6,789 & 8,550 & 7,999 & 2,176 & 2,336 \\
\hline R-squared & 0.217 & 0.022 & 0.033 & 0.218 & 0.182 & 0.024 \\
\hline $\begin{array}{l}\text { Note: For exposit } \\
1-7 \text {. The estimate } \\
\text { multinationals, } \\
\text { multinationals, al } \\
\text { controls for year } \\
\text { average index by }\end{array}$ & $\begin{array}{l}\text { onal reasons we or } \\
\text { for the remaining } \\
\text { ntrols for year an } \\
\text { o equal to average } \\
\text { nd country effect }\end{array}$ & $\begin{array}{l}\text { ly display the esti } \\
18 \text { source countri } \\
\text { country fixed } \\
\text { index by country } \\
\text { ntegrated and ind } \\
\text { tire period. } * * *\end{array}$ & $\begin{array}{l}\text { ates for the } 10 \text { la } \\
\text { with ownership } \\
\text { ect integrated an } \\
\text { cross the entire } \\
\text { try effects. Mana }\end{array}$ & $\begin{array}{l}\text { st source countri } \\
\text { Sweden are suppr } \\
\text { ndustry fixed eff } \\
\text { od. Management } \\
\text { ment6 - on the sa }\end{array}$ & $\begin{array}{l}\text { in Sweden corres } \\
\text { ssed. Managemen } \\
\text { cts. Management } \\
\text { - on the sample } \\
\text { aple of foreign M }\end{array}$ & $\begin{array}{l}\text { onding to Tables } \\
1 \text { - w/o domestic } \\
2 \text { - w/o domestic } \\
\text { of foreign MNEs, } \\
\text { JEs, also equal to } \\
\text { ectively. }\end{array}$ \\
\hline
\end{tabular}


Table 0A6.2: WMS management index calculated in different ways. Regressions weighted by the number of employees per country in the WMS data, 2000-2009.

\begin{tabular}{|c|c|c|c|c|c|c|}
\hline Variables & Management 1 & Management 2 & Management 3 & Management 4 & Management 5 & Management 6 \\
\hline Denmark & $\begin{array}{c}0.287 * * * \\
(0.100)\end{array}$ & $\begin{array}{c}0.278 * * * \\
(0.100)\end{array}$ & $\begin{array}{c}0.274 * * * \\
(0.100)\end{array}$ & $\begin{array}{c}0.273 * * * \\
(0.101)\end{array}$ & $\begin{array}{l}-0.039 \\
(0.115)\end{array}$ & $\begin{array}{c}0.009 \\
(0.109)\end{array}$ \\
\hline Finland & $\begin{array}{c}0.237 * * * \\
(0.086)\end{array}$ & $\begin{array}{c}0.278 * * * \\
(0.083)\end{array}$ & $\begin{array}{c}0.274 * * * \\
(0.083)\end{array}$ & $\begin{array}{c}0.196 * * \\
(0.087)\end{array}$ & $\begin{array}{l}-0.026 \\
(0.100)\end{array}$ & $\begin{array}{c}0.009 \\
(0.093)\end{array}$ \\
\hline France & $\begin{array}{c}0.468 \text { *** } \\
(0.048)\end{array}$ & $\begin{array}{c}0.466 * * * \\
(0.048)\end{array}$ & $\begin{array}{c}0.357 * * * \\
(0.035)\end{array}$ & $\begin{array}{c}0.363 * * * \\
(0.037)\end{array}$ & $\begin{array}{l}0.128^{*} \\
(0.066)\end{array}$ & $\begin{array}{c}0.197 * * * \\
(0.063)\end{array}$ \\
\hline Japan & $\begin{array}{c}0.368 * * * \\
(0.045)\end{array}$ & $\begin{array}{c}0.408 * * * \\
(0.044)\end{array}$ & $\begin{array}{c}0.436 * * * \\
(0.039)\end{array}$ & $\begin{array}{c}0.337 * * * \\
(0.041)\end{array}$ & $\begin{array}{l}0.124 * * \\
(0.063)\end{array}$ & $\begin{array}{c}0.138 * * \\
(0.060)\end{array}$ \\
\hline Netherlands & $\begin{array}{c}0.444 * * * \\
(0.063)\end{array}$ & $\begin{array}{c}0.362 * * * \\
(0.065)\end{array}$ & $\begin{array}{c}0.358 * * * \\
(0.065)\end{array}$ & $\begin{array}{c}0.402 * * * \\
(0.064)\end{array}$ & $\begin{array}{c}0.091 \\
(0.079)\end{array}$ & $\begin{array}{c}0.092 \\
(0.077)\end{array}$ \\
\hline Norway & $\begin{array}{c}0.160 \\
(0.115)\end{array}$ & $\begin{array}{c}0.179 \\
(0.116)\end{array}$ & $\begin{array}{c}0.175 \\
(0.116)\end{array}$ & $\begin{array}{c}0.123 \\
(0.117)\end{array}$ & $\begin{array}{l}-0.150 \\
(0.131)\end{array}$ & $\begin{array}{l}-0.090 \\
(0.124)\end{array}$ \\
\hline Switzerland & $\begin{array}{c}0.419 * * * \\
(0.051)\end{array}$ & $\begin{array}{c}0.426 * * * \\
(0.051)\end{array}$ & $\begin{array}{c}0.422 * * * \\
(0.051)\end{array}$ & $\begin{array}{c}0.400 * * * \\
(0.051)\end{array}$ & $\begin{array}{l}0.131^{*} \\
(0.069)\end{array}$ & $\begin{array}{c}0.156^{* *} \\
(0.065)\end{array}$ \\
\hline UK & $\begin{array}{c}0.414 * * * \\
(0.059)\end{array}$ & $\begin{array}{c}0.440 * * * \\
(0.060)\end{array}$ & $\begin{array}{c}0.161 * * * \\
(0.032)\end{array}$ & $\begin{array}{c}0.169 * * * \\
(0.037)\end{array}$ & $\begin{array}{l}0.144^{*} \\
(0.076)\end{array}$ & $\begin{array}{l}0.170^{* *} \\
(0.073)\end{array}$ \\
\hline Germany & $\begin{array}{c}0.356 * * * \\
(0.036)\end{array}$ & $\begin{array}{c}0.378 * * * \\
(0.035)\end{array}$ & $\begin{array}{c}0.377 * * * \\
(0.028)\end{array}$ & $\begin{array}{c}0.290 * * * \\
(0.030)\end{array}$ & $\begin{array}{l}0.038 \\
(0.057)\end{array}$ & $\begin{array}{c}0.108^{* *} \\
(0.054)\end{array}$ \\
\hline US & $\begin{array}{c}0.510 * * * \\
(0.026)\end{array}$ & $\begin{array}{c}0.493 * * * \\
(0.024)\end{array}$ & $\begin{array}{c}0.536 \text { *** } \\
(0.020)\end{array}$ & $\begin{array}{c}0.422 * * * \\
(0.022)\end{array}$ & $\begin{array}{c}0.217 * * * \\
(0.050)\end{array}$ & $\begin{array}{c}0.222 * * * \\
(0.047)\end{array}$ \\
\hline Constant & $\begin{array}{c}2.866 * * * \\
(0.758) \\
\end{array}$ & $\begin{array}{c}2.851 * * * \\
(0.010)\end{array}$ & $\begin{array}{c}2.855 * * * \\
(0.010)\end{array}$ & $\begin{array}{c}4.561 * * * \\
(1.492)\end{array}$ & $\begin{array}{c}3.210 * * * \\
(0.856)\end{array}$ & $\begin{array}{c}3.120 * * * \\
(0.041)\end{array}$ \\
\hline Sample in WMS & $\begin{array}{l}\text { Domestic firms } \\
\text { and foreign } \\
\text { MNEs }\end{array}$ & $\begin{array}{l}\text { Domestic firms } \\
\text { and foreign } \\
\text { MNEs }\end{array}$ & All firms & All firms & Foreign MNEs & Foreign MNEs \\
\hline $\begin{array}{l}\text { Pairwise } \\
\text { country and } \\
\text { year FE }\end{array}$ & Yes & No & No & Yes & Yes & No \\
\hline Industry FE & Yes & No & No & Yes & Yes & No \\
\hline Observations & 6,367 & 6,789 & 8,550 & 7,999 & 2,176 & 2,336 \\
\hline R-squared & 0.226 & 0.095 & 0.103 & 0.198 & 0.125 & 0.027 \\
\hline $\begin{array}{l}\text { Note: For exposit } \\
1-7 \text {. The estimate } \\
\text { multinationals, co } \\
\text { multinationals, al } \\
\text { controls for year } \\
\text { average index by }\end{array}$ & $\begin{array}{l}\text { onal reasons we on } \\
\text { for the remaining } \\
\text { trols for year and } \\
\text { o equal to average } \\
\text { nd country effect in } \\
\text { ountry across the }\end{array}$ & $\begin{array}{l}\text { y display the estin } \\
8 \text { source countries } \\
\text { ountry fixed effec } \\
\text { adex by country a } \\
\text { egrated and indus } \\
\text { tire period. } * * *\end{array}$ & $\begin{array}{l}\text { tes for the } 10 \text { larg } \\
\text { vith ownership in } \\
\text { ithegrated and ind } \\
\text { oss the entire peri } \\
\text { y effects. Manage } \\
\text { * show significa }\end{array}$ & $\begin{array}{l}\text { t source countries } \\
\text { weden are suppre } \\
\text { try fixed effects. } \\
\text { 1. Management } 5 \\
\text { ent6 - on the sam } \\
\text { e at the } 1 \%, 5 \% \text {, }\end{array}$ & $\begin{array}{l}\text { Sweden correspo } \\
\text { ed. Management } 1 \\
\text { anagement } 2-\text { w/o } \\
\text { on the sample of } \\
\text { e of foreign MNEs } \\
\text { d } 10 \% \text { levels, res }\end{array}$ & $\begin{array}{l}\text { ding to Tables } \\
\text { w/o domestic } \\
\text { domestic } \\
\text { reign MNEs, } \\
\text { also equal to } \\
\text { ectively. }\end{array}$ \\
\hline
\end{tabular}


Table 7 with different management index and regression weights

Table 0A7.1: Management and productivity, 2000-2009 (at least 10 employees). Comparing management indices weighted by the number of observations per country.

\begin{tabular}{|c|c|c|c|c|c|c|c|c|}
\hline \multirow[b]{3}{*}{ Management } & \multicolumn{3}{|c|}{ Management 1} & \multirow{2}{*}{$\frac{\text { Management } 2}{(4)}$} & \multicolumn{3}{|c|}{ Management 5} & \multirow{2}{*}{$\frac{\text { Management } 6}{(8)}$} \\
\hline & (1) & (2) & (3) & & (5) & (6) & (7) & \\
\hline & $\begin{array}{c}0.071 * * \\
(0.030) \\
\end{array}$ & $\begin{array}{l}0.047 * * \\
(0.022) \\
\end{array}$ & $\begin{array}{l}0.039 * \\
(0.023) \\
\end{array}$ & $\begin{array}{c}0.063^{* *} \\
(0.025) \\
\end{array}$ & $\begin{array}{c}0.107 * * * \\
(0.033) \\
\end{array}$ & $\begin{array}{c}0.077 * * * \\
(0.019) \\
\end{array}$ & $\begin{array}{c}0.071 * * * \\
(0.024)\end{array}$ & $\begin{array}{c}0.063 * * \\
(0.025) \\
\end{array}$ \\
\hline $\log (\mathrm{K} / \mathrm{L})$ & & $\begin{array}{c}0.117 * * * \\
(0.011)\end{array}$ & $\begin{array}{c}0.117 * * * \\
(0.011)\end{array}$ & $\begin{array}{c}0.117 * * * \\
(0.011)\end{array}$ & & $\begin{array}{c}0.117 * * * \\
(0.011)\end{array}$ & $\begin{array}{c}0.117 * * * \\
(0.011)\end{array}$ & $\begin{array}{c}0.117 * * * \\
(0.011)\end{array}$ \\
\hline $\log (\mathrm{L})$ & & $\begin{array}{c}0.026^{* *} \\
(0.012)\end{array}$ & $\begin{array}{c}0.025 * * \\
(0.012)\end{array}$ & $\begin{array}{c}0.025^{* *} \\
(0.012)\end{array}$ & & $\begin{array}{l}0.024 * \\
(0.012)\end{array}$ & $\begin{array}{l}0.024 * \\
(0.012)\end{array}$ & $\begin{array}{c}0.025^{* *} \\
(0.012)\end{array}$ \\
\hline $\begin{array}{l}\text { Share skill } \\
\text { high }\end{array}$ & & $\begin{array}{c}0.695 * * * \\
(0.097) \\
\end{array}$ & $\begin{array}{c}0.689 * * * \\
(0.095) \\
\end{array}$ & $\begin{array}{c}0.695 * * * \\
(0.093) \\
\end{array}$ & & $\begin{array}{c}0.694 * * * \\
(0.096) \\
\end{array}$ & $\begin{array}{c}0.692 * * * \\
(0.093) \\
\end{array}$ & $\begin{array}{c}0.695 * * * \\
(0.093) \\
\end{array}$ \\
\hline GDP & & & $\begin{array}{c}0.0101 \\
(0.00693)\end{array}$ & $\begin{array}{c}0.00929 \\
(0.00713)\end{array}$ & & & $\begin{array}{c}0.00989 \\
(0.00706)\end{array}$ & $\begin{array}{c}0.00933 \\
(0.00713)\end{array}$ \\
\hline Weighted & & & -0.0489 & -0.0490 & & & -0.0788 & -0.0490 \\
\hline distance & & & $(0.110)$ & $(0.117)$ & & & $(0.121)$ & $(0.117)$ \\
\hline Rule of law & & & $\begin{array}{c}0.047 * * \\
(0.019)\end{array}$ & $\begin{array}{l}0.044 * \\
(0.022)\end{array}$ & & & $\begin{array}{l}0.043 * \\
(0.022)\end{array}$ & $\begin{array}{l}0.044 * \\
(0.022)\end{array}$ \\
\hline $\begin{array}{l}\text { Business } \\
\text { freedom } \\
\text { Freedom to } \\
\text { trade }\end{array}$ & & & $\begin{array}{l}-0.000 \\
(0.013) \\
-0.054 \\
(0.044) \\
\end{array}$ & $\begin{array}{l}-0.003 \\
(0.011) \\
-0.042 \\
(0.042) \\
\end{array}$ & & & $\begin{array}{l}-0.004 \\
(0.008) \\
-0.043 \\
(0.038) \\
\end{array}$ & $\begin{array}{l}-0.003 \\
(0.011) \\
-0.042 \\
(0.042) \\
\end{array}$ \\
\hline Observations & 8,813 & 8,813 & 8,813 & & 8,813 & 8,813 & 8,813 & 8,813 \\
\hline R-squared & 0.059 & 0.164 & 0.166 & & 0.062 & 0.166 & 0.167 & 0.167 \\
\hline $\begin{array}{l}\text { Note: The depen } \\
\text { domestic multin } \\
\text { average index by } \\
\text { Management6 - } \\
\text { observations (fir } \\
* * *, * *, * \text { show }\end{array}$ & $\begin{array}{l}\text { it variable } \\
\text { nals, contr } \\
\text { untry acro } \\
\text { the sample } \\
\text { per count } \\
\text { nificance a }\end{array}$ & $\begin{array}{l}\text { ged value ac } \\
\text { or year and c } \\
\text { entire perio } \\
\text { oreign MNE } \\
11 \text { regression } \\
1 \%, 5 \%, \text { and }\end{array}$ & $\begin{array}{l}\text { per employee } \\
\text { ry fixed effec } \\
\text { anagement } 5 \\
\text { o equal to av } \\
\text { lude interacte } \\
6 \text { levels, respe }\end{array}$ & $\begin{array}{l}\text { gement indices fo } \\
\text { rated and industry } \\
\text { e sample of forei } \\
\text { ndex by country a } \\
\text { ndividual time an } \\
\text {. }\end{array}$ & $\begin{array}{l}\text { ent source c } \\
\text { effects. Man } \\
\text { Es, controls } \\
\text { e entire peri } \\
\text { ry fixed effe }\end{array}$ & $\begin{array}{l}\text { ies are take } \\
\text { lent } 2-\text { w/o } \\
\text { ear and cour } \\
\text { he manage } \\
\text { s well as cl }\end{array}$ & $\begin{array}{l}\mathrm{m} \text { Table OA } \\
\text { estic multin } \\
\text { ffect integra } \\
\text { indices are } \\
\text { ed standard }\end{array}$ & $\begin{array}{l}\text { agement } 1 \text { - w/o } \\
\text { also equal to } \\
\text { ndustry effects. } \\
\text { using number of } \\
\text { he country level. }\end{array}$ \\
\hline
\end{tabular}


Table 0A7.2: Management and productivity, 2000-2009 (at least 10 employees). Comparing management indices weighted by number of firms per country in the WMS data. Productivity regressions weighted by number of observations (firms) per country in the Swedish firm data.

\begin{tabular}{|c|c|c|c|c|c|c|c|c|}
\hline \multirow[b]{3}{*}{ Management } & \multicolumn{3}{|c|}{ Management 1} & \multirow{2}{*}{$\begin{array}{c}\text { Management } 2 \\
\text { (4) }\end{array}$} & \multicolumn{3}{|c|}{ Management 5} & \multirow{2}{*}{$\begin{array}{c}\text { Management } 6 \\
(8)\end{array}$} \\
\hline & (1) & (2) & (3) & & (5) & (6) & (7) & \\
\hline & $\begin{array}{c}0.087 * * * \\
(0.028)\end{array}$ & $\begin{array}{l}0.054 * * \\
(0.022)\end{array}$ & $\begin{array}{c}0.038 \\
(0.025)\end{array}$ & $\begin{array}{c}0.106 * * * \\
(0.030)\end{array}$ & $\begin{array}{c}0.150 * * * \\
(0.020)\end{array}$ & $\begin{array}{c}0.100 * * * \\
(0.015)\end{array}$ & $\begin{array}{c}0.108 * * * \\
(0.028)\end{array}$ & $\begin{array}{c}0.106 * * * \\
(0.030)\end{array}$ \\
\hline $\log (\mathrm{K} / \mathrm{L})$ & & $\begin{array}{c}0.125 * * * \\
(0.011)\end{array}$ & $\begin{array}{c}0.125 * * * \\
(0.011)\end{array}$ & $\begin{array}{c}0.126 * * * \\
(0.011)\end{array}$ & & $\begin{array}{c}0.125 * * * \\
(0.011)\end{array}$ & $\begin{array}{c}0.125 * * * \\
(0.011)\end{array}$ & $\begin{array}{c}0.126 * * * \\
(0.011)\end{array}$ \\
\hline $\log (\mathrm{L})$ & & $\begin{array}{c}0.018 \\
(0.013)\end{array}$ & $\begin{array}{c}0.017 \\
(0.014)\end{array}$ & $\begin{array}{c}0.015 \\
(0.013)\end{array}$ & & $\begin{array}{c}0.015 \\
(0.013)\end{array}$ & $\begin{array}{c}0.015 \\
(0.013)\end{array}$ & $\begin{array}{c}0.015 \\
(0.013)\end{array}$ \\
\hline $\begin{array}{l}\text { Share skill } \\
\text { high }\end{array}$ & & $\begin{array}{c}0.723 * * * \\
(0.107)\end{array}$ & $\begin{array}{c}0.719 * * * \\
(0.108)\end{array}$ & $\begin{array}{c}0.715^{* * * *} \\
(0.109)\end{array}$ & & $\begin{array}{c}0.710 * * * \\
(0.109)\end{array}$ & $\begin{array}{c}0.713 * * * \\
(0.109)\end{array}$ & $\begin{array}{c}0.715 * * * \\
(0.109)\end{array}$ \\
\hline GDP & & & $\begin{array}{c}0.0175 * * * \\
(0.00611)\end{array}$ & $\begin{array}{c}0.0152 * * * \\
(0.00444)\end{array}$ & & & $\begin{array}{c}0.0199 * * * \\
(0.00578)\end{array}$ & $\begin{array}{c}0.0153 * * * \\
(0.00444)\end{array}$ \\
\hline Weighted & & & -0.117 & $-0.134 *$ & & & $-0.241 * *$ & $-0.134 *$ \\
\hline distance & & & $(0.102)$ & $(0.0729)$ & & & $(0.101)$ & $(0.0729)$ \\
\hline Rule of law & & & $\begin{array}{c}0.104 * * * \\
(0.034)\end{array}$ & $\begin{array}{c}0.125^{* *} \\
(0.048)\end{array}$ & & & $\begin{array}{c}0.102 * * \\
(0.040)\end{array}$ & $\begin{array}{c}0.125^{* *} \\
(0.048)\end{array}$ \\
\hline $\begin{array}{l}\text { Business } \\
\text { freedom } \\
\text { Freedom to } \\
\text { trade }\end{array}$ & & & $\begin{array}{c}0.002 \\
(0.017) \\
-0.188^{* *} \\
(0.088)\end{array}$ & $\begin{array}{c}-0.003 \\
(0.013) \\
-0.146^{* *} \\
(0.064)\end{array}$ & & & $\begin{array}{c}-0.002 \\
(0.010) \\
-0.114^{* *} \\
(0.055)\end{array}$ & $\begin{array}{c}-0.003 \\
(0.013) \\
-0.146^{* *} \\
(0.064)\end{array}$ \\
\hline $\begin{array}{l}\text { Observations } \\
\text { R-squared }\end{array}$ & 8,813 & 8,813 & 8,813 & $\begin{array}{l}8,813 \\
0183\end{array}$ & 8,813 & 8,813 & 8,813 & $\begin{array}{l}8,813 \\
0183\end{array}$ \\
\hline $\begin{array}{l}\text { Note: The deper } \\
\text { w/o domestic m } \\
\text { to average index } \\
\text { effects. Manage } \\
\text { are weighted usi } \\
\text { standard errors a }\end{array}$ & $\begin{array}{l}\text { nt variable i } \\
\text { inationals, ce } \\
y \text { country act } \\
\text { nt } 6 \text { - on the } \\
\text { number of } \\
\text { he country le }\end{array}$ & $\begin{array}{l}\text { ogged value a } \\
\text { trols for year } \\
\text { s the entire } \mathrm{p} \\
\text { ample of forei } \\
\text { ervations (fir } \\
\text { e. } * * *, * *, *\end{array}$ & $\begin{array}{l}\text { ded per emplc } \\
\text { d country fix } \\
\text { iod. Managen } \\
\text { MNEs, also } \\
\text { s) per country } \\
\text { ow significan }\end{array}$ & $\begin{array}{l}\text { Management indice } \\
\text { ects integrated and } \\
\text { - on the sample of } \\
\text { to average index b } \\
\text { regressions include } \\
\text { the } 1 \%, 5 \% \text {, and } 10\end{array}$ & $\begin{array}{l}\text { ferent sourc } \\
\text { fixed effec } \\
\text { MNEs, con } \\
\text { y across the } \\
\text { ted and indi } \\
\text { s, respective }\end{array}$ & $\begin{array}{l}\text { Managemen } \\
\text { s for year a } \\
\text { ire period. } \\
\text { al time and }\end{array}$ & $\begin{array}{l}\text { n from Table } \\
\text { w/o domesti } \\
\text { ountry effect } \\
\text { management } \\
\text { ustry fixed ef }\end{array}$ & $\begin{array}{l}\text { Management } 1 \text { - } \\
\text { ationals, also equal } \\
\text { d and industry } \\
\text { and the regressions } \\
\text { well as clustered }\end{array}$ \\
\hline
\end{tabular}


Table 0A7.3: Management and productivity, 2000-2009 (at least 10 employees). Comparing management indices weighted by number of employees per country in the WMS data.

\begin{tabular}{|c|c|c|c|c|c|c|c|c|}
\hline \multirow[b]{3}{*}{ Management } & \multicolumn{3}{|c|}{ Management 1} & \multirow{2}{*}{$\frac{\text { Management } 2}{(4)}$} & \multicolumn{3}{|c|}{ Management 5} & \multirow{2}{*}{$\frac{\text { Management } 6}{(8)}$} \\
\hline & (1) & (2) & (3) & & (5) & (6) & (7) & \\
\hline & $\begin{array}{c}0.083 * * * \\
(0.029) \\
\end{array}$ & $\begin{array}{l}0.057 * * \\
(0.021) \\
\end{array}$ & $\begin{array}{l}0.049 * * \\
(0.023) \\
\end{array}$ & $\begin{array}{c}0.063 * * \\
(0.025) \\
\end{array}$ & $\begin{array}{l}0.091 * * * \\
(0.030) \\
\end{array}$ & $\begin{array}{c}0.066 * * * \\
(0.018) \\
\end{array}$ & $\begin{array}{c}0.060 * * * \\
(0.021) \\
\end{array}$ & $\begin{array}{c}0.063 * * \\
(0.025) \\
\end{array}$ \\
\hline $\log (\mathrm{K} / \mathrm{L})$ & & $\begin{array}{c}0.117 * * * \\
(0.011)\end{array}$ & $\begin{array}{c}0.117 * * * \\
(0.011)\end{array}$ & $\begin{array}{c}0.117 * * * \\
(0.011)\end{array}$ & & $\begin{array}{c}0.117 * * * \\
(0.011)\end{array}$ & $\begin{array}{c}0.117 * * * \\
(0.011)\end{array}$ & $\begin{array}{c}0.117 * * * \\
(0.011)\end{array}$ \\
\hline $\log (\mathrm{L})$ & & $\begin{array}{c}0.025^{* *} \\
(0.012)\end{array}$ & $\begin{array}{c}0.025 * * \\
(0.012)\end{array}$ & $\begin{array}{c}0.025 * * \\
(0.012)\end{array}$ & & $\begin{array}{c}0.025 * * \\
(0.012)\end{array}$ & $\begin{array}{c}0.025^{* *} \\
(0.012)\end{array}$ & $\begin{array}{c}0.025 * * \\
(0.012)\end{array}$ \\
\hline $\begin{array}{l}\text { Share skill } \\
\text { high }\end{array}$ & & $\begin{array}{c}0.692 * * * \\
(0.096) \\
\end{array}$ & $\begin{array}{c}0.689 * * * * \\
(0.094) \\
\end{array}$ & $\begin{array}{c}0.695 * * * \\
(0.093) \\
\end{array}$ & & $\begin{array}{c}0.694 * * * \\
(0.096) \\
\end{array}$ & $\begin{array}{c}0.692 * * * \\
(0.093) \\
\end{array}$ & $\begin{array}{c}0.695 * * * \\
(0.093) \\
\end{array}$ \\
\hline GDP & & & $\begin{array}{c}0.00942 \\
(0.00692)\end{array}$ & $\begin{array}{c}0.00929 \\
(0.00713)\end{array}$ & & & $\begin{array}{c}0.00962 \\
(0.00711)\end{array}$ & $\begin{array}{c}0.00933 \\
(0.00713)\end{array}$ \\
\hline Weighted & & & -0.0529 & -0.0490 & & & -0.0705 & -0.0490 \\
\hline distance & & & $(0.111)$ & (0.117) & & & $(0.122)$ & $(0.117)$ \\
\hline Rule of law & & & $\begin{array}{l}0.045 * * \\
(0.020)\end{array}$ & $\begin{array}{l}0.044 * \\
(0.022)\end{array}$ & & & $\begin{array}{l}0.044 * \\
(0.022)\end{array}$ & $\begin{array}{l}0.044^{*} \\
(0.022)\end{array}$ \\
\hline $\begin{array}{l}\text { Business } \\
\text { freedom }\end{array}$ & & & $\begin{array}{l}-0.001 \\
(0.012)\end{array}$ & $\begin{array}{l}-0.003 \\
(0.011)\end{array}$ & & & $\begin{array}{l}-0.004 \\
(0.010)\end{array}$ & $\begin{array}{l}-0.003 \\
(0.011)\end{array}$ \\
\hline $\begin{array}{l}\text { Freedom to } \\
\text { trade }\end{array}$ & & & $\begin{array}{l}-0.049 \\
(0.043) \\
\end{array}$ & $\begin{array}{c}-0.042 \\
(0.042) \\
\end{array}$ & & & $\begin{array}{c}-0.044 \\
(0.040) \\
\end{array}$ & $\begin{array}{c}-0.042 \\
(0.042) \\
\end{array}$ \\
\hline Observations & 8,813 & 8,813 & 8,813 & 8,813 & 8,813 & 8,813 & 8,813 & 8,813 \\
\hline R-squared & 0.060 & 0.165 & 0.166 & 0.167 & 0.061 & 0.165 & 0.167 & 0.167 \\
\hline $\begin{array}{l}\text { Note: The depe } \\
\text { domestic multi } \\
\text { average index } \\
\text { Management6 } \\
\text { number of emp } \\
* * *, * *, * \text { shov }\end{array}$ & $\begin{array}{l}\text { country acr } \\
\mathrm{n} \text { the sample } \\
\text { yees per cou } \\
\text { gnificance }\end{array}$ & $\begin{array}{l}\text { oll regressi } \\
1 \%, 5 \% \text {, an }\end{array}$ & $\begin{array}{l}\text { lanagement } \\
\text { o equal to a } \\
\text { clude intera } \\
\% \text { levels, res }\end{array}$ & $\begin{array}{l}\text { individual time } \\
\text { ind by country }\end{array}$ & $\begin{array}{l}\text { s, controls f } \\
\text { entire perio } \\
\text { stry fixed eff }\end{array}$ & $\begin{array}{l}\text { es are taken } \\
\text { nt } 2 \text { - w/o d } \\
\text { ond countr } \\
\text { manageme } \\
\text { s well as clu }\end{array}$ & $\begin{array}{l}\text { Table OA6.2 } \\
\text { tic multinatic } \\
\text { ect integratec } \\
\text { dices are wei } \\
\text { d standard er }\end{array}$ & $\begin{array}{l}\text { gement } 1 \text { - w/o } \\
\text { o equal to } \\
\text { lustry effects. } \\
\text { ing average } \\
\text { he country level. }\end{array}$ \\
\hline
\end{tabular}


Table 0A7.4: Management and productivity, 2000-2009 (at least 10 employees). Comparing management indices weighted by number of employees per country in the WMS data. Productivity regressions weighted by number of employees per country in the Swedish firm data.

\begin{tabular}{|c|c|c|c|c|c|c|c|c|}
\hline \multirow[b]{3}{*}{ Management } & \multicolumn{3}{|c|}{ Management 1} & \multirow{2}{*}{$\begin{array}{c}\text { Management } 2 \\
(4)\end{array}$} & \multicolumn{3}{|c|}{ Management 5} & \multirow{2}{*}{$\frac{\text { Management } 6}{(8)}$} \\
\hline & (1) & (2) & (3) & & (5) & (6) & (7) & \\
\hline & $\begin{array}{c}0.087 * * * \\
(0.027) \\
\end{array}$ & $\begin{array}{l}0.064^{* *} \\
(0.024) \\
\end{array}$ & $\begin{array}{l}0.045^{*} \\
(0.025) \\
\end{array}$ & $\begin{array}{l}0.064 * * \\
(0.026) \\
\end{array}$ & $\begin{array}{c}0.100^{* * * *} \\
(0.024) \\
\end{array}$ & $\begin{array}{c}0.075^{* * *} * \\
(0.020) \\
\end{array}$ & $\begin{array}{l}0.058^{* *} \\
(0.024) \\
\end{array}$ & $\begin{array}{l}0.064 * * \\
(0.026) \\
\end{array}$ \\
\hline $\log (\mathrm{K} / \mathrm{L})$ & & $\begin{array}{c}0.117 * * * \\
(0.010)\end{array}$ & $\begin{array}{c}0.117 * * * \\
(0.010)\end{array}$ & $\begin{array}{c}0.118 * * * \\
(0.010)\end{array}$ & & $\begin{array}{c}0.117 * * * \\
(0.010)\end{array}$ & $\begin{array}{c}0.117 * * * \\
(0.010)\end{array}$ & $\begin{array}{c}0.118 * * * \\
(0.010)\end{array}$ \\
\hline $\log (\mathrm{L})$ & & $\begin{array}{c}0.019 \\
(0.014)\end{array}$ & $\begin{array}{c}0.020 \\
(0.014)\end{array}$ & $\begin{array}{c}0.020 \\
(0.014)\end{array}$ & & $\begin{array}{c}0.018 \\
(0.014)\end{array}$ & $\begin{array}{c}0.020 \\
(0.014)\end{array}$ & $\begin{array}{c}0.020 \\
(0.014)\end{array}$ \\
\hline $\begin{array}{l}\text { Share skill } \\
\text { high }\end{array}$ & & $\begin{array}{c}0.748 * * * \\
(0.097) \\
\end{array}$ & $\begin{array}{c}0.753 * * * \\
(0.093) \\
\end{array}$ & $\begin{array}{c}0.755 * * * \\
(0.092) \\
\end{array}$ & & $\begin{array}{c}0.747 * * * \\
(0.097) \\
\end{array}$ & $\begin{array}{c}0.753 * * * \\
(0.093) \\
\end{array}$ & $\begin{array}{c}0.755^{* * * *} \\
(0.092) \\
\end{array}$ \\
\hline GDP & & & $\begin{array}{l}0.0146 * * \\
(0.00683)\end{array}$ & $\begin{array}{c}0.0130^{*} \\
(0.00657)\end{array}$ & & & $\begin{array}{l}0.0141^{* *} \\
(0.00649)\end{array}$ & $\begin{array}{c}0.0131^{*} \\
(0.00657)\end{array}$ \\
\hline Weighted & & & -0.107 & -0.0868 & & & -0.116 & -0.0868 \\
\hline distance & & & $(0.106)$ & $(0.103)$ & & & $(0.109)$ & $(0.104)$ \\
\hline Rule of law & & & $\begin{array}{c}0.076 \text { ** } \\
(0.031)\end{array}$ & $\begin{array}{c}0.074 * * \\
(0.033)\end{array}$ & & & $\begin{array}{l}0.074 * * \\
(0.033)\end{array}$ & $\begin{array}{l}0.074 * * \\
(0.033)\end{array}$ \\
\hline $\begin{array}{l}\text { Business } \\
\text { freedom }\end{array}$ & & & $\begin{array}{l}-0.009 \\
(0.013)\end{array}$ & $\begin{array}{l}-0.011 \\
(0.011)\end{array}$ & & & $\begin{array}{l}-0.012 \\
(0.011)\end{array}$ & $\begin{array}{l}-0.011 \\
(0.011)\end{array}$ \\
\hline $\begin{array}{l}\text { Freedom to } \\
\text { trade }\end{array}$ & & & $\begin{array}{l}-0.080 \\
(0.049) \\
\end{array}$ & $\begin{array}{l}-0.070 \\
(0.046) \\
\end{array}$ & & & $\begin{array}{l}-0.075 \\
(0.047) \\
\end{array}$ & $\begin{array}{l}-0.070 \\
(0.046) \\
\end{array}$ \\
\hline Observations & 8,813 & 8,813 & 8,813 & 8,813 & 8,813 & 8,813 & 8,813 & 8,813 \\
\hline R-squared & 0.062 & 0.169 & 0.172 & 0.173 & 0.063 & 0.169 & 0.173 & 0.173 \\
\hline $\begin{array}{l}\text { Note: The dep } \\
\text { w/o domestic } \\
\text { equal to avera } \\
\text { industry effec } \\
\text { regressions ar } \\
\text { as clustered st }\end{array}$ & $\begin{array}{l}\text { nt variable } \mathrm{i} \\
\text { inationals, } \mathrm{c} \\
\text { dex by coun } \\
\text { anagement6 } \\
\text { ighted using } \\
\text { rd errors at } \mathrm{ag}\end{array}$ & $\begin{array}{l}\text { gged value } \\
\text { rols for yea } \\
\text { across the } \\
\text { n the samp } \\
\text { erage numb } \\
\text { country lev }\end{array}$ & $\begin{array}{l}\text { ded per empl } \\
\mathrm{d} \text { country fi } \\
\text { re period. M } \\
\mathrm{f} \text { foreign } \mathrm{MI} \\
\mathrm{f} \text { employees } \\
* * *, * *, * \text { sh }\end{array}$ & $\begin{array}{l}\text { Management ind } \\
\text { ects integrated a } \\
\text { nent } 5 \text { - on the s } \\
\text { so equal to avera } \\
\text { untry. All regre } \\
\text { nificance at the }\end{array}$ & $\begin{array}{l}\mathrm{r} \text { different } \mathrm{so} \\
\text { istry fixed ef } \\
\text { of foreign } \mathrm{M} \\
\text { ex by countr } \\
\text { nclude inter } \\
\text {, and } 10 \% \mathrm{l}\end{array}$ & $\begin{array}{l}\text { e countries } \\
\text { ts. Managem } \\
\text { s, controls f } \\
\text { ross the ent } \\
d \text { and indivi } \\
\text { s, respective }\end{array}$ & $\begin{array}{l}\text { ken from } T \\
2 \text { - w/o dom } \\
\text { ar and coun } \\
\text { eriod. The } n \\
\text { time and in }\end{array}$ & $\begin{array}{l}\text { Management } 1 \\
\text { tionals, also } \\
\text { egrated and } \\
\text { indices and } \\
\text { effects as well }\end{array}$ \\
\hline
\end{tabular}


Table 7 including different number of countries

Table 0A7.5: Management and productivity, 2000-2009 (at least 10 employees). Comparing management indices only including 10 most important countries.

\begin{tabular}{|c|c|c|c|c|c|c|c|c|}
\hline & \multicolumn{3}{|c|}{ Management 1} & \multirow{2}{*}{$\frac{\text { Management } 2}{(4)}$} & \multicolumn{3}{|c|}{ Management 5} & \multirow{2}{*}{$\frac{\text { Management } 6}{(8)}$} \\
\hline & (1) & (2) & (3) & & (5) & (6) & (7) & \\
\hline Management & $\begin{array}{r}0.062 * * \\
(0.021) \\
\end{array}$ & $\begin{array}{l}0.039 * \\
(0.017) \\
\end{array}$ & $\begin{array}{c}0.043 * * \\
(0.018) \\
\end{array}$ & $\begin{array}{c}0.062 * * * \\
(0.014) \\
\end{array}$ & $\begin{array}{c}0.069 * * * \\
(0.013) \\
\end{array}$ & $\begin{array}{c}0.045^{* * * *} \\
(0.012) \\
\end{array}$ & $\begin{array}{c}0.057 * * * \\
(0.013) \\
\end{array}$ & $\begin{array}{c}0.062^{* * *} \\
(0.014) \\
\end{array}$ \\
\hline $\log (\mathrm{K} / \mathrm{L})$ & & $0.122 * * *$ & $0.122 * * *$ & $0.123 * * *$ & & $0.122 * * *$ & $0.123 * * *$ & $0.123^{* * *}$ \\
\hline $\log (\mathrm{L})$ & & $\begin{array}{l}(0.011) \\
0.025^{*} \\
(0.013)\end{array}$ & $\begin{array}{l}(0.011) \\
0.025^{*} \\
(0.013)\end{array}$ & $\begin{array}{c}(0.011) \\
0.023 \\
(0.013)\end{array}$ & & $\begin{array}{c}(0.011) \\
0.024 \\
(0.013)\end{array}$ & $\begin{array}{c}(0.011) \\
0.023 \\
(0.013)\end{array}$ & $\begin{array}{c}(0.011) \\
0.023 \\
(0.013)\end{array}$ \\
\hline $\begin{array}{l}\text { Share skill } \\
\text { high }\end{array}$ & & $\begin{array}{c}0.660 * * * \\
(0.109) \\
\end{array}$ & $\begin{array}{c}0.664 * * * \\
(0.107) \\
\end{array}$ & $\begin{array}{c}0.663 * * * \\
(0.107) \\
\end{array}$ & & $\begin{array}{c}0.653 * * * \\
(0.109) \\
\end{array}$ & $\begin{array}{c}0.661 * * * \\
(0.107) \\
\end{array}$ & $\begin{array}{c}0.663 * * * \\
(0.107) \\
\end{array}$ \\
\hline GDP & & & $\begin{array}{c}0.0212 * * * \\
(0.00427)\end{array}$ & $\begin{array}{c}0.0193 * * * \\
(0.00285)\end{array}$ & & & $\begin{array}{c}0.0221 * * * \\
(0.00336)\end{array}$ & $\begin{array}{c}0.0194 * * * \\
(0.00284)\end{array}$ \\
\hline $\begin{array}{l}\text { Weighted } \\
\text { distance }\end{array}$ & & & $\begin{array}{r}-0.197 * * * \\
(0.0488)\end{array}$ & $\begin{array}{c}-0.193 * * * \\
(0.0361)\end{array}$ & & & $\begin{array}{c}-0.257 * * * \\
(0.0499)\end{array}$ & $\begin{array}{c}-0.193 * * * \\
(0.0360)\end{array}$ \\
\hline Rule of law & & & $\begin{array}{c}0.126^{* *} \\
(0.041)\end{array}$ & $\begin{array}{c}0.158 * * * \\
(0.048)\end{array}$ & & & $\begin{array}{c}0.128 * * \\
(0.043)\end{array}$ & $\begin{array}{c}0.158 * * * \\
(0.048)\end{array}$ \\
\hline $\begin{array}{l}\text { Business } \\
\text { freedom }\end{array}$ & & & $\begin{array}{l}-0.001 \\
(0.016)\end{array}$ & $\begin{array}{l}-0.006 \\
(0.013)\end{array}$ & & & $\begin{array}{l}-0.007 \\
(0.012)\end{array}$ & $\begin{array}{l}-0.006 \\
(0.013)\end{array}$ \\
\hline $\begin{array}{l}\text { Freedom to } \\
\text { trade }\end{array}$ & & & $\begin{array}{l}-0.090 \\
(0.098) \\
\end{array}$ & $\begin{array}{r}-0.087 \\
(0.083) \\
\end{array}$ & & & $\begin{array}{r}-0.079 \\
(0.084) \\
\end{array}$ & $\begin{array}{l}-0.087 \\
(0.083) \\
\end{array}$ \\
\hline Observations & 8,082 & 8,082 & 8,082 & 8,082 & 8,082 & 8,082 & 8,082 & 8,082 \\
\hline R-squared & 0.063 & 0.169 & 0.173 & 0.174 & 0.066 & 0.171 & 0.174 & 0.174 \\
\hline $\begin{array}{l}\text { Note: The depc } \\
\text { domestic multi } \\
\text { average index } \\
\text { effects. Manag } \\
\text { Sweden corres } \\
\text { clustered stand }\end{array}$ & $\begin{array}{l}\text { untry acro } \\
\text { nt6 - on the } \\
\text { ling to tabl } \\
\text { errors at the }\end{array}$ & $\begin{array}{l}\text { gged value } \\
\text { for year and } \\
\text { he entire pe } \\
\text { nple of fore } \\
-6 \text { are inclu } \\
\text { intry level. }\end{array}$ & $\begin{array}{l}\text { ded per employ } \\
\text { ountry fixed effe } \\
\text { d. Management } \\
\text { MNEs, also eq } \\
\text { in the estimati } \\
*, * *, * \text { show si }\end{array}$ & $\begin{array}{l}\text { Management indi } \\
\text { integrated and in } \\
\text { on the sample of } \\
\text { to average index } \\
\text { All regressions i } \\
\text { icance at the } 1 \% \text {, }\end{array}$ & $\begin{array}{l}\text { different so } \\
\text { fixed effects } \\
\mathrm{n} \text { MNEs, cor } \\
\text { intry across t } \\
\text { interacted a } \\
\text { nd } 10 \% \text { leve }\end{array}$ & $\begin{array}{l}\text { countries a } \\
\text { anagement } \\
\text { s for year at } \\
\text { ntire period } \\
\text { adividual tir } \\
\text { espectively. }\end{array}$ & $\begin{array}{l}\text { ken from Ta } \\
\text { /o domestic } \\
\text { ountry effect } \\
\text { ly the } 10 \text { lar } \\
\text { nd industry f }\end{array}$ & $\begin{array}{l}\text { gement } 1 \text { - w/o } \\
\text { als, also equal to } \\
\text { and industry } \\
\text { countries in } \\
\text { as well as }\end{array}$ \\
\hline
\end{tabular}


Table 0A7.6: Management and productivity, 2000-2009 (at least 10 employees). Comparing management indices only for 23 countries (removing potential outliers).

\begin{tabular}{|c|c|c|c|c|c|c|c|c|}
\hline & \multicolumn{3}{|c|}{ "Management 1} & \multirow{2}{*}{$\begin{array}{c}\text { Management } 2 \\
(4)\end{array}$} & \multicolumn{3}{|c|}{ Management 5} & \multirow{2}{*}{$\begin{array}{c}\text { Management } 6 \\
(8)\end{array}$} \\
\hline & $(1)$ & $(2)$ & (3) & & (5) & (6) & (7) & \\
\hline Management & $\begin{array}{c}0.064 * * * \\
(0.020) \\
\end{array}$ & $\begin{array}{l}0.040 * * \\
(0.016) \\
\end{array}$ & $\begin{array}{l}0.033^{*} \\
(0.018) \\
\end{array}$ & $\begin{array}{l}0.047 * \\
(0.023) \\
\end{array}$ & $\begin{array}{c}0.075 * * * \\
(0.017) \\
\end{array}$ & $\begin{array}{c}0.049 * * * \\
(0.013) \\
\end{array}$ & $\begin{array}{l}0.046 * * \\
(0.019) \\
\end{array}$ & $\begin{array}{l}0.047 * \\
(0.023) \\
\end{array}$ \\
\hline \multirow[t]{2}{*}{$\log (\mathrm{K} / \mathrm{L})$} & & $0.117 * * *$ & $0.118 * * *$ & $0.118 * * *$ & & $0.118 * * *$ & $0.118 * * *$ & $0.118 * * *$ \\
\hline & & $(0.011)$ & $(0.011)$ & $(0.011)$ & & $(0.011)$ & $(0.011)$ & $(0.011)$ \\
\hline \multirow[t]{2}{*}{$\log (\mathrm{L})$} & & $0.026^{* *}$ & $0.026^{* * *}$ & $0.025^{* *}$ & & $0.025^{*}$ & $0.025^{* *}$ & $0.025^{* *}$ \\
\hline & & $(0.012)$ & $(0.012)$ & $(0.012)$ & & $(0.012)$ & $(0.012)$ & $(0.012)$ \\
\hline \multirow{2}{*}{$\begin{array}{l}\text { Share skill } \\
\text { high }\end{array}$} & & $0.679 * * *$ & $0.686 * * *$ & $0.688 * * *$ & & $0.675 * * *$ & $0.684 * * *$ & $0.688 * * *$ \\
\hline & & $(0.097)$ & $(0.095)$ & $(0.094)$ & & $(0.097)$ & $(0.095)$ & $(0.094)$ \\
\hline \multirow[t]{2}{*}{ GDP } & & & $0.0193 * * *$ & $0.0194 * * *$ & & & $0.0199 * * *$ & $0.0195 * * *$ \\
\hline & & & $(0.00321)$ & $(0.00337)$ & & & $(0.00268)$ & $(0.00336)$ \\
\hline \multirow{2}{*}{$\begin{array}{l}\text { Weighted } \\
\text { distance }\end{array}$} & & & $-0.209 * * *$ & $-0.224 * * *$ & & & $-0.249 * * *$ & $-0.224 * * *$ \\
\hline & & & $(0.0412)$ & $(0.0525)$ & & & $(0.0489)$ & $(0.0526)$ \\
\hline \multirow[t]{2}{*}{ Rule of law } & & & $0.039 *$ & 0.032 & & & 0.033 & 0.032 \\
\hline & & & $(0.020)$ & $(0.023)$ & & & $(0.022)$ & $(0.023)$ \\
\hline Business & & & 0.001 & -0.001 & & & -0.003 & -0.001 \\
\hline freedom & & & $(0.013)$ & $(0.011)$ & & & $(0.010)$ & $(0.011)$ \\
\hline Freedom to & & & -0.037 & -0.033 & & & -0.033 & -0.033 \\
\hline trade & & & $(0.045)$ & $(0.042)$ & & & $(0.041)$ & $(0.042)$ \\
\hline Observations & 8,705 & 8,705 & 8,705 & 8,705 & 8,705 & 8,705 & 8,705 & 8,705 \\
\hline R-squared & 0.061 & 0.164 & 0.167 & 0.168 & 0.063 & 0.165 & 0.168 & 0.168 \\
\hline \multicolumn{9}{|c|}{$\begin{array}{l}\text { Note: The dependent variable is logged value added per employee. Management indices for different source countries are taken from Table } 6: \text { Management } 1-\text { w/o } \\
\text { domestic multinationals, controls for year and country fixed effects integrated and industry fixed effects. Management } 2 \text { - w/o domestic multinationals, also equal to } \\
\text { average index by country across the entire period. Management } 5 \text { - on the sample of foreign MNEs, controls for year and country effect integrated and industry effects. } \\
\text { Management } 6 \text { - on the sample of foreign MNEs, also equal to average index by country across the entire period. From the original sample of } 28 \text { countries, Australia, } \\
\text { Bahrain, Poland, Saudi Arabia, and Singapore are omitted. All regressions include interacted and individual time and industry fixed effects as well as clustered standard } \\
\text { errors at the country level. ***, *** show significance at the } 1 \%, 5 \% \text {, and } 10 \% \text { levels, respectively. }\end{array}$} \\
\hline
\end{tabular}


Table 7 only including firms with at least 100 employees

Table 0A7.7: Management and productivity, 2000-2009 (at least 100 employees). Comparing management indices.

\begin{tabular}{|c|c|c|c|c|c|c|c|c|}
\hline & \multicolumn{3}{|c|}{ Management 1} & \multirow{2}{*}{$\begin{array}{c}\text { Management } 2 \\
(4)\end{array}$} & \multicolumn{3}{|c|}{ Management 5} & \multirow{2}{*}{$\begin{array}{c}\text { Management } 6 \\
(8)\end{array}$} \\
\hline & (1) & (2) & (3) & & (5) & (6) & (7) & \\
\hline Management & $\begin{array}{c}0.059 * * * \\
(0.016) \\
\end{array}$ & $\begin{array}{c}0.048 * * * \\
(0.013) \\
\end{array}$ & $\begin{array}{r}0.047 * * \\
(0.018) \\
\end{array}$ & $\begin{array}{c}0.068 * * * \\
(0.022) \\
\end{array}$ & $\begin{array}{c}0.065 * * * \\
(0.019) \\
\end{array}$ & $\begin{array}{c}0.058 * * * \\
(0.013) \\
\end{array}$ & $\begin{array}{c}0.063 * * * * \\
(0.018) \\
\end{array}$ & $\begin{array}{c}0.068 * * * * \\
(0.022) \\
\end{array}$ \\
\hline $\log (\mathrm{K} / \mathrm{L})$ & & $\begin{array}{c}0.128 * * * \\
(0.019)\end{array}$ & $\begin{array}{c}0.128 * * * \\
(0.019)\end{array}$ & $\begin{array}{c}0.129 * * * \\
(0.019)\end{array}$ & & $\begin{array}{l}0.129 * * * \\
(0.019)\end{array}$ & $\begin{array}{c}0.128 * * * \\
(0.019)\end{array}$ & $\begin{array}{c}0.129 * * * \\
(0.019)\end{array}$ \\
\hline $\log (\mathrm{L})$ & & $\begin{array}{l}0.044^{*} \\
(0.026)\end{array}$ & $\begin{array}{l}0.045^{*} \\
(0.026)\end{array}$ & $\begin{array}{l}0.045^{*} \\
(0.025)\end{array}$ & & $\begin{array}{l}0.044 * \\
(0.026)\end{array}$ & $\begin{array}{l}0.044 * \\
(0.025)\end{array}$ & $\begin{array}{l}0.045^{*} \\
(0.025)\end{array}$ \\
\hline $\begin{array}{l}\text { Share skill } \\
\text { high }\end{array}$ & & $\begin{array}{c}0.819 * * * \\
(0.185) \\
\end{array}$ & $\begin{array}{c}0.826 * * * \\
(0.184) \\
\end{array}$ & $\begin{array}{c}0.832 * * * \\
(0.183) \\
\end{array}$ & & $\begin{array}{c}0.821 * * * \\
(0.185) \\
\end{array}$ & $\begin{array}{c}0.829 * * * \\
(0.184) \\
\end{array}$ & $\begin{array}{c}0.832 * * * \\
(0.183) \\
\end{array}$ \\
\hline GDP & & & $\begin{array}{c}0.00359 \\
(0.00802)\end{array}$ & $\begin{array}{c}0.00331 \\
(0.00834)\end{array}$ & & & $\begin{array}{c}0.00337 \\
(0.00808)\end{array}$ & $\begin{array}{c}0.00335 \\
(0.00834)\end{array}$ \\
\hline Weighted & & & -0.0841 & -0.0835 & & & -0.0985 & -0.0835 \\
\hline distance & & & $(0.110)$ & $(0.115)$ & & & $(0.115)$ & $(0.115)$ \\
\hline Rule of law & & & $\begin{array}{l}-0.023 \\
(0.021)\end{array}$ & $\begin{array}{l}-0.021 \\
(0.021)\end{array}$ & & & $\begin{array}{l}-0.023 \\
(0.021)\end{array}$ & $\begin{array}{l}-0.021 \\
(0.021)\end{array}$ \\
\hline $\begin{array}{l}\text { Business } \\
\text { freedom }\end{array}$ & & & $\begin{array}{c}0.010 \\
(0.015)\end{array}$ & $\begin{array}{c}0.007 \\
(0.014)\end{array}$ & & & $\begin{array}{c}0.005 \\
(0.013)\end{array}$ & $\begin{array}{c}0.007 \\
(0.014)\end{array}$ \\
\hline $\begin{array}{l}\text { Freedom to } \\
\text { trade }\end{array}$ & & & $\begin{array}{l}-0.009 \\
(0.040) \\
\end{array}$ & $\begin{array}{l}-0.000 \\
(0.038) \\
\end{array}$ & & & $\begin{array}{l}-0.001 \\
(0.038) \\
\end{array}$ & $\begin{array}{l}-0.000 \\
(0.038) \\
\end{array}$ \\
\hline Observations & 3,647 & 3,647 & 3,647 & 3,647 & 3,647 & 3,647 & 3,647 & 3,647 \\
\hline R-squared & 0.129 & 0.274 & 0.275 & 0.276 & 0.129 & 0.275 & 0.276 & 0.276 \\
\hline $\begin{array}{l}\text { Note: The dep } \\
\text { domestic mul } \\
\text { average index } \\
\text { Management } 6 \\
\text { the estimation } \\
\text { significance a }\end{array}$ & $\begin{array}{l}\text { ountry acros } \\
\text { the sample } \\
1 \text { regressions } \\
1 \%, 5 \% \text {, and }\end{array}$ & $\begin{array}{l}\text { oreign MN } \\
\text { clude intera } \\
\% \text { levels, } r\end{array}$ & $\begin{array}{l}\text { ded per empl } \\
\text { untry fixed } \\
\text { l. Manageme } \\
\text { also equal to } \\
\text { d and indivic } \\
\text { ectively. }\end{array}$ & $\begin{array}{l}\text { Management ind } \\
\text { integrated and in } \\
\text { on the sample of } \\
\text { ge index by cour } \\
\text { ne and industry } f\end{array}$ & $\begin{array}{l}\text { MNEs, cor } \\
\text { fects as well }\end{array}$ & $\begin{array}{l}\text { ls for year } \\
\text { riod. Only } \\
\text { clustered st }\end{array}$ & $\begin{array}{l}\text { fen from Tal } \\
\text { o domestic } 1 \\
\text { untry effect } \\
\text { with at least } \\
\text { errors at th }\end{array}$ & $\begin{array}{l}\text { ment } 1-\text { w/o } \\
\text { also equal to } \\
\text { industry effects. } \\
\text { es are included in } \\
1 . * * * * * * \text { show }\end{array}$ \\
\hline
\end{tabular}


Table 7 using non-standardized management indices

Table 0A7.8: Management and productivity, 2000-2009 (at least 10 employees). Using non-standardized management indices (same specifications as in Table 7 in the paper).

\begin{tabular}{|c|c|c|c|c|c|c|c|c|}
\hline \multirow[b]{3}{*}{ Management } & \multicolumn{3}{|c|}{ Management 1} & \multirow{2}{*}{$\begin{array}{c}\text { Management } 2 \\
(4)\end{array}$} & \multicolumn{3}{|c|}{ Management 5} & \multirow{2}{*}{$\begin{array}{c}\text { Management } 6 \\
(8)\end{array}$} \\
\hline & $(1)$ & (2) & (3) & & $(5)$ & (6) & (7) & \\
\hline & $\begin{array}{c}0.494 * * \\
(0.179) \\
\end{array}$ & $\begin{array}{c}0.337 * * \\
(0.131) \\
\end{array}$ & $\begin{array}{l}0.283^{*} \\
(0.141) \\
\end{array}$ & $\begin{array}{l}0.316^{* * *} \\
(0.123)\end{array}$ & $\begin{array}{c}0.492 * * * \\
(0.161) \\
\end{array}$ & $\begin{array}{c}0.353 * * * \\
(0.099) \\
\end{array}$ & $\begin{array}{c}0.316^{* * *} \\
(0.117) \\
\end{array}$ & $\begin{array}{c}0.316^{* *} \\
(0.123) \\
\end{array}$ \\
\hline $\log (\mathrm{K} / \mathrm{L})$ & & $\begin{array}{c}0.117 * * * \\
(0.011)\end{array}$ & $\begin{array}{c}0.117 * * * \\
(0.011)\end{array}$ & $\begin{array}{c}0.117 * * * \\
(0.011)\end{array}$ & & $\begin{array}{c}0.117 * * * \\
(0.011)\end{array}$ & $\begin{array}{c}0.117 * * * \\
(0.011)\end{array}$ & $\begin{array}{c}0.117 * * * \\
(0.011)\end{array}$ \\
\hline $\log (\mathrm{L})$ & & $\begin{array}{c}0.026 * * \\
(0.012)\end{array}$ & $\begin{array}{c}0.025^{* *} \\
(0.012)\end{array}$ & $\begin{array}{c}0.025 * * \\
(0.012)\end{array}$ & & $\begin{array}{c}0.025^{* *} \\
(0.012)\end{array}$ & $\begin{array}{c}0.025 * * \\
(0.012)\end{array}$ & $\begin{array}{c}0.025 * * \\
(0.012)\end{array}$ \\
\hline $\begin{array}{l}\text { Share skill } \\
\text { high }\end{array}$ & & $\begin{array}{c}0.693 * * * \\
(0.096) \\
\end{array}$ & $\begin{array}{c}0.689 * * * \\
(0.094)\end{array}$ & $\begin{array}{c}0.695 * * * \\
(0.093) \\
\end{array}$ & & $\begin{array}{c}0.693 * * * \\
(0.096) \\
\end{array}$ & $\begin{array}{c}0.692 * * * \\
(0.093) \\
\end{array}$ & $\begin{array}{c}0.695 * * * \\
(0.093) \\
\end{array}$ \\
\hline GDP & & & $\begin{array}{c}0.00955 \\
(0.00693)\end{array}$ & $\begin{array}{c}0.00929 \\
(0.00713)\end{array}$ & & & $\begin{array}{c}0.00970 \\
(0.00710)\end{array}$ & $\begin{array}{c}0.00933 \\
(0.00713)\end{array}$ \\
\hline Weighted & & & -0.0516 & -0.0490 & & & -0.0693 & -0.0490 \\
\hline distance & & & $(0.111)$ & $(0.117)$ & & & $(0.121)$ & $(0.117)$ \\
\hline Rule of law & & & $\begin{array}{c}0.045 * * \\
(0.020)\end{array}$ & $\begin{array}{l}0.044 * \\
(0.022)\end{array}$ & & & $\begin{array}{l}0.044 * \\
(0.022)\end{array}$ & $\begin{array}{l}0.044 * \\
(0.022)\end{array}$ \\
\hline $\begin{array}{l}\text { Business } \\
\text { freedom }\end{array}$ & & & $\begin{array}{l}-0.001 \\
(0.012)\end{array}$ & $\begin{array}{l}-0.003 \\
(0.011)\end{array}$ & & & $\begin{array}{l}-0.005 \\
(0.010)\end{array}$ & $\begin{array}{l}-0.003 \\
(0.011)\end{array}$ \\
\hline $\begin{array}{l}\text { Freedom to } \\
\text { trade }\end{array}$ & & & $\begin{array}{l}-0.050 \\
(0.043) \\
\end{array}$ & $\begin{array}{l}-0.042 \\
(0.042) \\
\end{array}$ & & & $\begin{array}{c}-0.043 \\
(0.040) \\
\end{array}$ & $\begin{array}{l}-0.042 \\
(0.042) \\
\end{array}$ \\
\hline Observations & 8,813 & 8,813 & 8,813 & 8,813 & 8,813 & 8,813 & 8,813 & 8,813 \\
\hline R-squared & 0.060 & 0.164 & 0.166 & 0.167 & 0.061 & 0.165 & 0.167 & 0.167 \\
\hline
\end{tabular}




\section{Table 8 with alternative samples}

Table OA8: Management and productivity (at least 10 employees). Results using merged WMS and Swedish firm level data.

\begin{tabular}{|c|c|c|c|c|c|c|}
\hline \multirow[b]{2}{*}{ Management } & (1) & (2) & (3) & (4) & (5) & (6) \\
\hline & $\begin{array}{c}0.078 \text { ** } \\
(0.034)\end{array}$ & $\begin{array}{c}0.079 * * \\
(0.031)\end{array}$ & $\begin{array}{c}0.080^{* *} \\
(0.032)\end{array}$ & $\begin{array}{c}0.052^{* *} \\
(0.025)\end{array}$ & $\begin{array}{c}0.042 * * \\
(0.021)\end{array}$ & $\begin{array}{l}0.041 * \\
(0.022)\end{array}$ \\
\hline \multirow[t]{2}{*}{ Degree $\mathrm{m}$} & 0.000 & -0.000 & -0.001 & $0.002 * *$ & $0.002 *$ & $0.002 *$ \\
\hline & $(0.001)$ & $(0.001)$ & $(0.001)$ & $(0.001)$ & $(0.001)$ & $(0.001)$ \\
\hline \multirow[t]{2}{*}{ Degree nm } & 0.003 & $0.005 * * *$ & $0.005 * * *$ & $0.005^{* *}$ & $0.006^{* * *}$ & $0.006^{* * *}$ \\
\hline & $(0.003)$ & $(0.002)$ & $(0.002)$ & $(0.002)$ & $(0.002)$ & $(0.002)$ \\
\hline \multirow[t]{2}{*}{$\log (\mathrm{K} / \mathrm{L})$} & & $0.219 * * *$ & $0.217 * * *$ & & $0.198 * * *$ & $0.196 * * *$ \\
\hline & & $(0.034)$ & $(0.036)$ & & $(0.026)$ & $(0.026)$ \\
\hline \multirow[t]{2}{*}{$\log (\mathrm{L})$} & & -0.015 & -0.018 & & -0.002 & -0.001 \\
\hline & & $(0.036)$ & $(0.037)$ & & $(0.027)$ & $(0.027)$ \\
\hline \multirow[t]{2}{*}{ GDP } & & & 0.00562 & & & 0.00234 \\
\hline & & & $(0.0105)$ & & & $(0.00957)$ \\
\hline \multirow{2}{*}{ Weighted distance } & & & -0.0479 & & & -0.119 \\
\hline & & & $(0.153)$ & & & $(0.109)$ \\
\hline \multirow{2}{*}{ Rule of law } & & & 0.111 & & & -0.040 \\
\hline & & & $(0.110)$ & & & $(0.091)$ \\
\hline \multirow{2}{*}{ Business freedom } & & & -0.058 & & & 0.005 \\
\hline & & & $(0.087)$ & & & $(0.075)$ \\
\hline \multirow{2}{*}{ Freedom to trade } & & & -0.328 & & & 0.008 \\
\hline & & & $(0.214)$ & & & $(0.099)$ \\
\hline Observations & 154 & 154 & 154 & 327 & 327 & 327 \\
\hline R-squared & 0.233 & 0.431 & 0.446 & 0.229 & 0.382 & 0.383 \\
\hline
\end{tabular}

Note: The dependent variable is logged value added per employee. Firms from 20 out of the 28 source countries of interest are present in the data. The independent variable of interest is firm-level WMS management score (instead of aggregated country-level score). Columns (1)-(3) include observations and corresponding management scores for 2006 and 2010 without any restrictions on number of employees at the firm and acquisitions. Only firms situated in Sweden with foreign owners are included. Columns (4)-(6) include observations for the 20 available countries of interest as well as for Sweden, imposing the same restrictions as in the main analysis. Firm controls are logged capital per employee, logged number of employees, share of skilled managers and share of skilled non-managers at firm. Country controls include GDP, CEPII population weighted distance measure, WGI level of legal institutions "Rule of Law", and Heritage Foundation measures of economic freedom. All regressions include interacted and individual time and industry controls as well as clustered standard errors at the firm level. Robust standard errors in parentheses: $\quad * * * \mathrm{p}<0.01, * * \mathrm{p}<0.05, * \mathrm{p}<0.1$ 


\section{Figure 1 with weighted productivity coefficient and management index}

Figure 1: Plotted estimates from regression models on productivity differences between foreign and Swedish firms in the manufacturing sector weighted by number of observations in the Swedish firm data for 28 countries against the management indices regressions weighted by number of observations in the WMS data.

Panel I - Management 1 - weighted index and regression

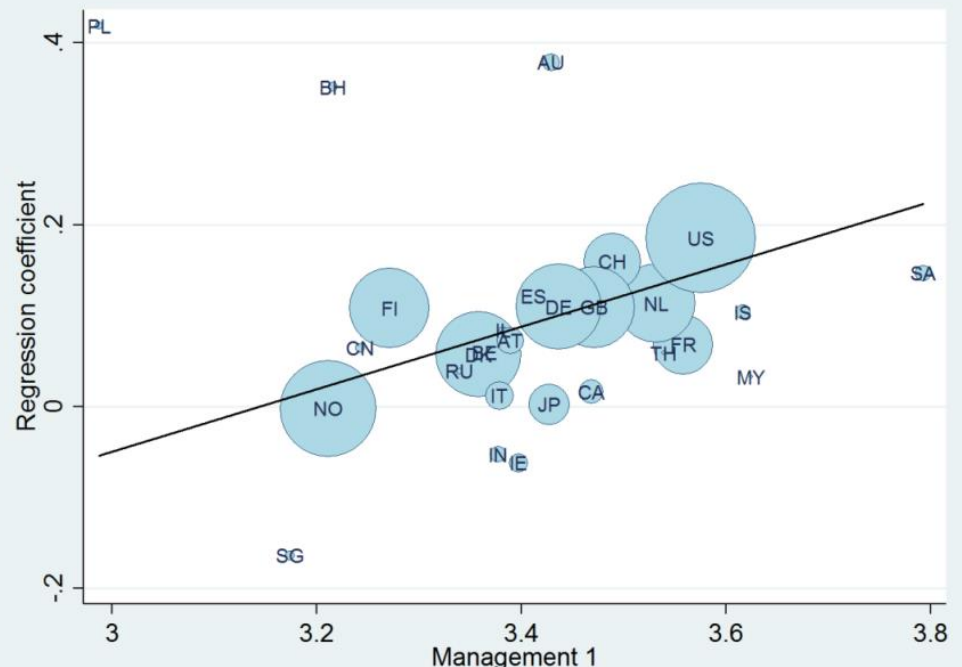

Panel II - Management 5 - weighted index and regression

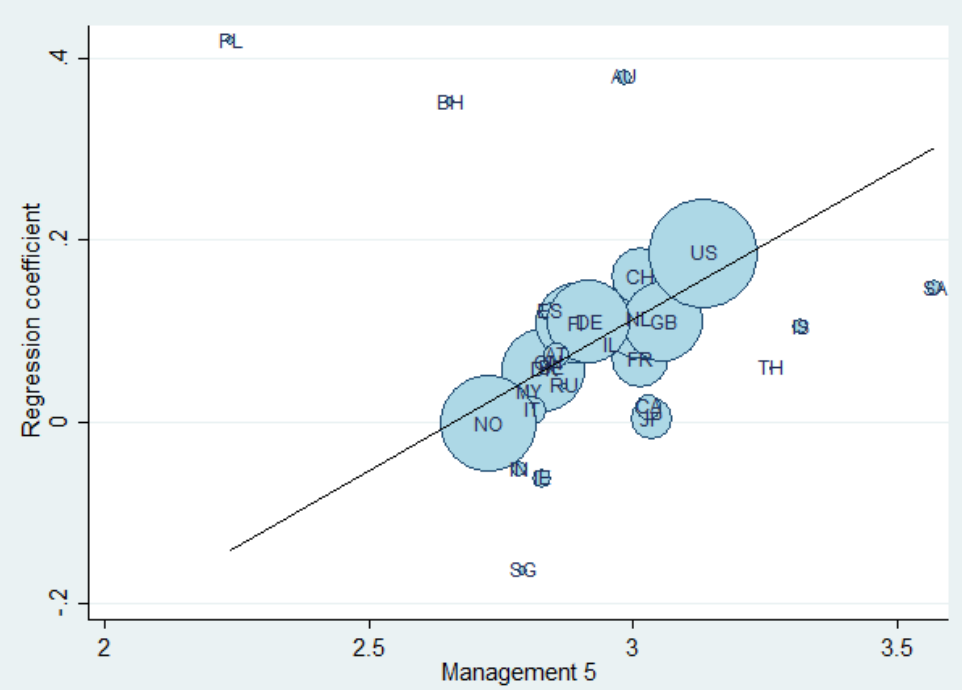

Note: Panel I and II plots country productivity coefficients weighted by number of observations (firms) per country in the firm data (not presented in any table) against management 1 (Table OA6.1 in the online appendix, column 1) and management 5 (Table OA6.1 in the online appendix, column 5) weighted by number of observations (firms) per country in the WMS data, respectively. The marker size and fitted line are weighted using average number of observations per year and country for each country. 